\title{
Modification of the home environment for the reduction of injuries (Review)
}

Turner S, Arthur G, Lyons RA, Weightman AL, Mann MK, Jones SJ, John A, Lannon S

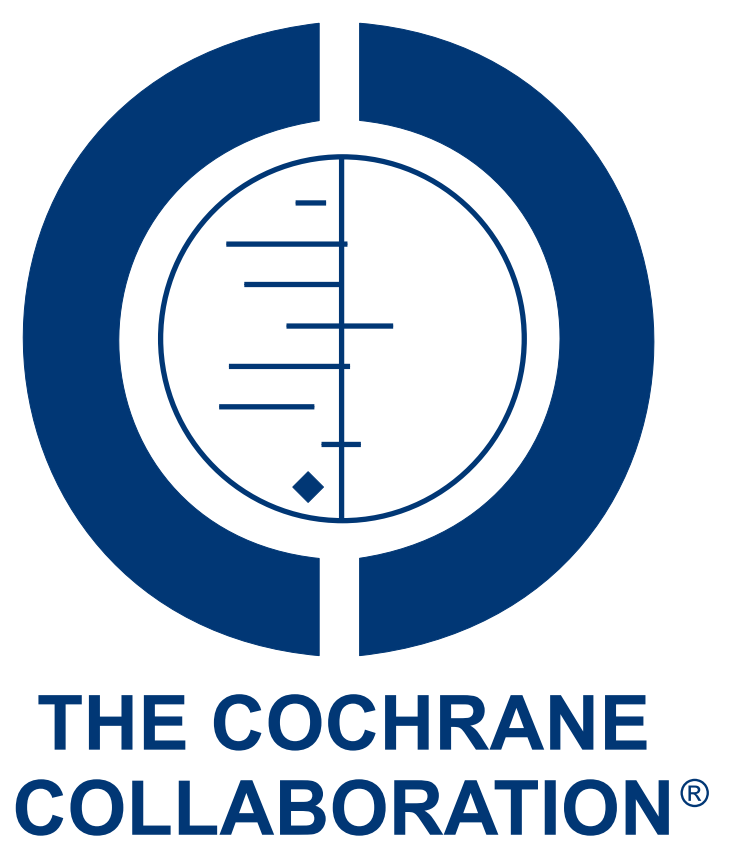

This is a reprint of a Cochrane review, prepared and maintained by The Cochrane Collaboration and published in The Cochrane Library 2011, Issue 11

http://www.thecochranelibrary.com

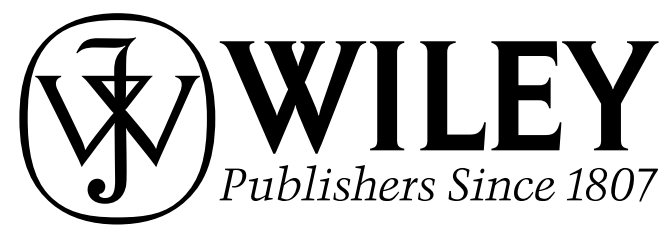

Modification of the home environment for the reduction of injuries (Review)

Copyright (C) 20II The Cochrane Collaboration. Published by John Wiley \& Sons, Ltd. 
TABLE OF CONTENTS

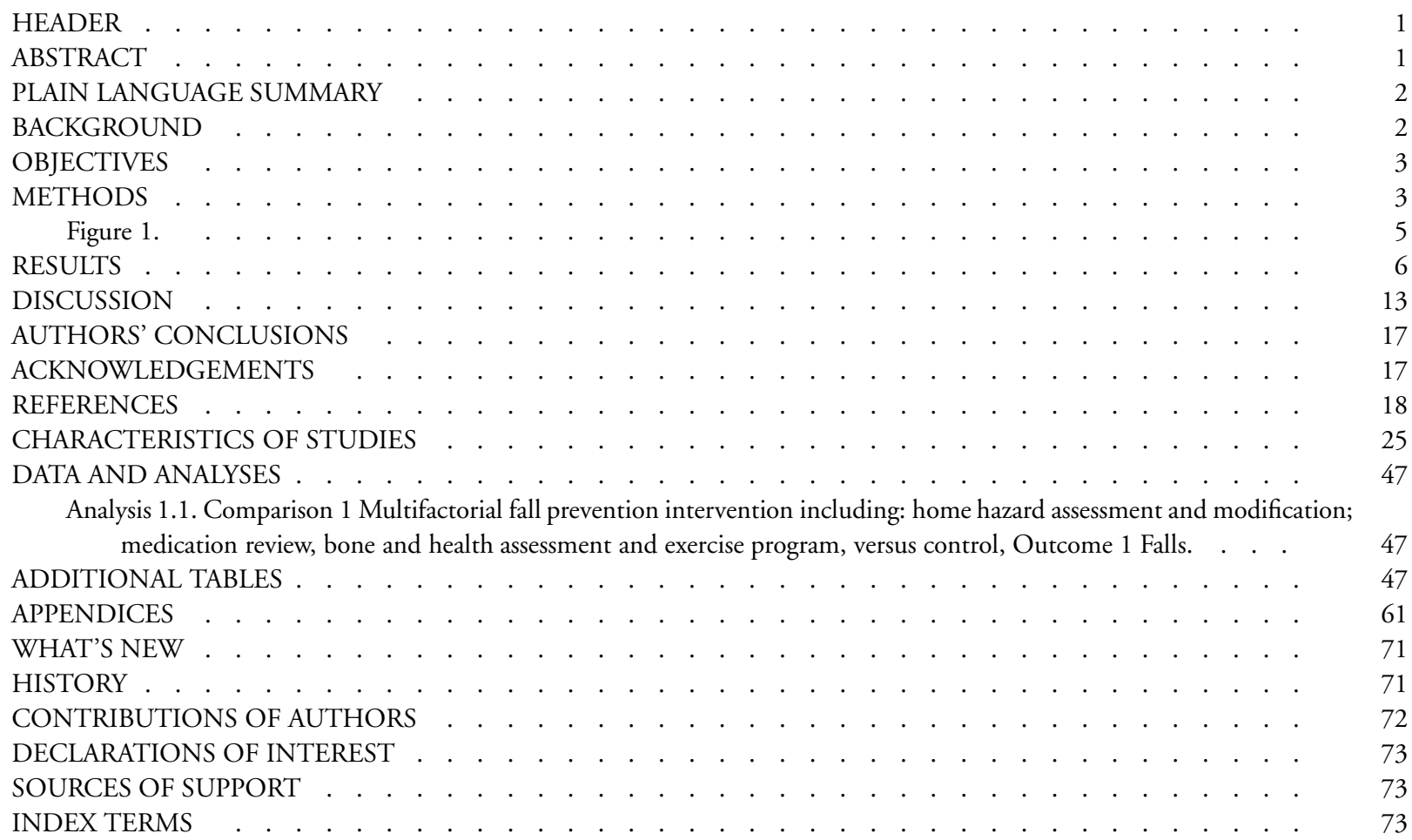




\title{
[Intervention Review] \\ Modification of the home environment for the reduction of injuries
}

\author{
Samantha Turner ${ }^{1}$, Geri Arthur ${ }^{2}$, Ronan A Lyons ${ }^{1}$, Alison L Weightman ${ }^{3}$, Mala K Mann ${ }^{3}$, Sarah J Jones ${ }^{4}$, Ann John ${ }^{2}$, Simon Lannon
}

${ }^{1}$ School of Medicine, Swansea University, Swansea, UK. ${ }^{2}$ Public Health Wales; Swansea University, School of Medicine, Swansea, UK. ${ }^{3}$ Support Unit for Research Evidence (SURE), Information Services, Cardiff University, Cardiff, UK. ${ }^{4}$ Public Health Wales; Department of Primary Care and Public Health, Cardiff University, Cardiff, UK. ${ }^{5}$ Welsh School of Architecture, Cardiff University, Cardiff, UK

Contact address: Samantha Turner, School of Medicine, Swansea University, Grove Building, Singleton Park, Swansea, SA2 8PP, UK. s.turner@swansea.ac.uk.

Editorial group: Cochrane Injuries Group.

Publication status and date: Edited (no change to conclusions), published in Issue 11, 2011.

Review content assessed as up-to-date: 30 November 2009.

Citation: Turner S, Arthur G, Lyons RA, Weightman AL, Mann MK, Jones SJ, John A, Lannon S. Modification of the home environment for the reduction of injuries. Cochrane Database of Systematic Reviews 2011, Issue 2. Art. No.: CD003600. DOI: 10.1002/14651858.CD003600.pub3.

Copyright (c) 2011 The Cochrane Collaboration. Published by John Wiley \& Sons, Ltd.

\section{A B S T R A C T}

\section{Background}

Injury in the home is common, accounting for approximately a third of all injuries. The majority of injuries to children under five and people aged 75 and older occur at home. Multifactorial injury prevention interventions have been shown to reduce injuries in the home. However, few studies have focused specifically on the impact of physical adaptations to the home environment and the effectiveness of such interventions needs to be ascertained.

\section{Objectives}

To determine the effect of modifications to the home environment on the reduction of injuries due to environmental hazards.

\section{Search methods}

We searched The Cochrane Library, MEDLINE, EMBASE and other specialised databases. We also scanned conference proceedings and reference lists. We contacted the first author of all included randomised controlled trials. The searches were last updated to the end of December 2009, and were not restricted by language or publication status.

\section{Selection criteria}

Randomised controlled trials.

\section{Data collection and analysis}

Two authors screened all abstracts for relevance, outcome and design. Two authors independently assessed methodological quality and extracted data from each eligible study. We performed meta-analysis to combine effect measures, using a random-effects model. We assessed heterogeneity using an $\mathrm{I}^{2}$ statistic and a $\mathrm{Chi}^{2}$ test. 


\section{Main results}

We found 28 published studies and one unpublished study. Only two studies were sufficiently similar to allow pooling of data for statistical analyses. Studies were divided into three groups; children, older people and the general population/mixed age group. None of the studies focusing on children or older people demonstrated a reduction in injuries that were a direct result of environmental modification in the home. One study in older people demonstrated a reduction in falls and one a reduction in falls and injurious falls that may have been due to hazard reduction. One meta-analysis was performed which examined the effects on falls of multifactorial interventions consisting of home hazard assessment and modification, medication review, health and bone assessment and exercise (RR $1.09,95 \%$ CI 0.97 to 1.23$)$.

\section{Authors' conclusions}

There is insufficient evidence to determine whether interventions focused on modifying environmental home hazards reduce injuries. Further interventions to reduce hazards in the home should be evaluated by adequately designed randomised controlled trials measuring injury outcomes. Recruitment of large study samples to measure effect must be a major consideration for future trials. Researchers should also consider using factorial designs to allow the evaluation of individual components of multifactorial interventions.

\section{PLAIN LANGUAGE SUMMARY}

\section{More evidence is needed to show whether or not altering the physical home environment by removing potential hazards reduces injuries}

Injuries in the home are very common. Most of the injuries to older people and children under five occur at home. Many people are encouraged to alter their home to try and reduce injury and injury risk. Common alterations include the fitting of locks on cupboards, installing stair gates, improvement of lighting in halls and stairways, and the removal of trip hazards. The review found that there is insufficient evidence from studies to show that such changes reduce the number of injuries in the home but does not conclude that these interventions are ineffective. Home alterations need to be evaluated by larger and better designed studies which include injuries in their outcomes.

\section{B A C K G R O U N D}

Injury in the home environment is an extremely common event, accounting for around a third of injuries in all age groups. The majority of injuries of children under five and people aged 75 and over occur in the home (DTI 1997; Lilley 1995; Lyons 2002). A European Union report (EU 2006) describes injury as the number one killer of children, adolescents and young adults; a major cause of disability, morbidity and healthcare costs; as detrimental to European Union production and unequal in its impact on social groups. The report cites children, adolescents and the elderly as priority groups for addressing safety issues. The World Health Organization (WHO 2006) estimated that within its Member States, 875,000 children and adolescents under the age of 18 died each year due to injury and approximately $70 \%$ of these deaths were due to accidental injury. One study reported that up to $44 \%$ of accidental injuries occur in the home (Scheidt 1995). It is unclear what proportion of these injuries are caused by hazards in the home. There is evidence from certain reviews to suggest that it is possi- ble to reduce injuries in the home by using multifactorial, injury prevention interventions (Coleman 1996; Health Development Agency 2003; Lyons 1998; NHS CRD 1996; Towner 2001; Van Haastregt 2000a). Subsequently, this evidence has found its way into policy documents and strategies prepared to prevent injuries in the home.

In England, the National Service Framework for Older People sets as a standard the development of an integrated falls prevention service in every acute hospital (DoH 2001). National Institute of Health and Clinical Excellence (NICE) guidance (NICE 2004) states that all older people who experience recurrent falls or are at risk of falling should be considered for an individualised multifactorial intervention. This advice was based on non-experimental, descriptive studies. This message was reiterated recently in UK government guidance to reduce falls and fractures with early intervention paramount (DH 2009). Research which examined the views of older people towards fall prevention strategies highlighted 
that interventions perceived as overbearing or restrictive were not popular and advice to be constantly vigilant for fall hazards could be disempowering (Yardley 2005). Older people favoured positive messages about benefits of interventions and the opportunity to choose strategies that suited them.

In setting up such services, a balance needs to be struck between the amount of resource spent on reducing intrinsic risk factors for falls (for example, excess or inappropriate medication, visual and balance problems) and extrinsic factors (for example, presence of environmental hazards). There appears to be a lack of similar guidelines in relation to injury prevention for children, although some guidance is currently being formulated, notably by NICE in the UK. This may reflect the lack of good quality scientific evidence available.

Existing reviews, however, have looked at any interventions that prevent falls and injuries and have not determined the relative importance of tackling intrinsic and extrinsic factors. The aim of this review, therefore, was to determine whether modification of the home environment reduces injuries in the home. It is hoped that the results of the review may inform and alert clinicians, practitioners and the public to gaps in the evidence and provide suggestions for the testing of future interventions. In addition, the conclusions will guide the research and policy development communities and government departments engaged in policy development. This is particularly important, given the development of cross-disciplinary collaboration in the field of injury prevention and because government policy, strategy and implementation documents should now directly reflect the results of research evidence.

\section{O B JE C T IVES}

To determine the effect of modifications to the home environment on the reduction of injuries, with the primary focus being interventions which reduce physical hazards in the home.

This review does not include interventions to promote smoke alarm ownership and function. These are the focus of an existing Cochrane review (DiGuiseppi 2001); interventions to prevent injuries caused by items brought into the home such as household chemicals and firearms; home-based items unrelated to building structure such as hip protectors for the elderly, also the subject of an existing Cochrane review (Parker 2005); medicines, bottles or toys; or injuries related to chronic exposures such as environmental lead.

\section{METHODS}

\section{Criteria for considering studies for this review}

\section{Types of studies}

Randomised controlled trials (RCTs).

\section{Types of participants}

People of all age groups who are at home (that is, in the place they would normally eat and sleep), in areas where housing is normally architect-designed and always subject to housing regulations.

\section{Types of interventions}

Eligible interventions are those which focus on modifying physical hazards including the building fabric or 'fixtures and fittings' (that is, removable items within a property that are fastened or attached to the building fabric) in the domestic environment, and where modifications such as the installation of grab rails, stair gates, fireguards, cupboard locks, hot-water tap adaptations and lighting adjustments, have been included.

We have included interventions which take a multifactorial approach (that is, have modification plus education or action on other risk factors). We have included studies which include the installation of smoke alarms alongside other physical interventions but not those where provision of smoke alarms was the sole intervention.

We excluded interventions which did not focus on reducing acute physical injuries (for example studies reducing chronic exposure to lead or nitrogen dioxide). We excluded any intervention where the focus has been to change the home environment solely for noninjury benefits (for example, improved quality of life of disabled individuals).

\section{Types of outcome measures}

- Change in injury rate or risk.

- Change in prevalence of safety features.

- Change in prevalence of hazards.

\section{Search methods for identification of studies}

\section{Electronic searches}

We searched the following electronic databases:

- ASSIA (1987 to December 2009)

- British Nursing Index (BNI) (1985 to December 2009)

- CINAHL (1994-December 2009)

- Cochrane Library (1996-December 2009)

- EMBASE (1947 to 2009 Week 50)

- ICONDA (1976 to December 2009)

- MEDLINE (1966 to November Week 3 2009)

- MEDLINE In-Process (1996 to November Week 3 2009)

- OpenSIGLE (1980 to 2005) 
- Planex (formerly the IDOX Information Service) (2004 to December 2009)

- RIBA-British Architectural Library Catalogue (2004 to December 2009)

- SafetyLit (2004 to December 2009)

- Urbadisc (Acompline and Urbaline) (1970 to December 2004)

- Web of Science

- Science Citation Index and Social Sciences Citation
Index (1970 to December 2009)

- Conference Proceedings Citation Index (1990 to December 2009)

We searched the electronic databases to December 2009, with the exception of OpenSIGLE which we searched to 2005 when updating ceased. Electronic searches of 12 databases yielded 4509 hits in the most recent update (2004 to December 2009) (see Figure 1). We have provided the complete search strategies in Appendix 1. 
Figure I. Flow chart of search process

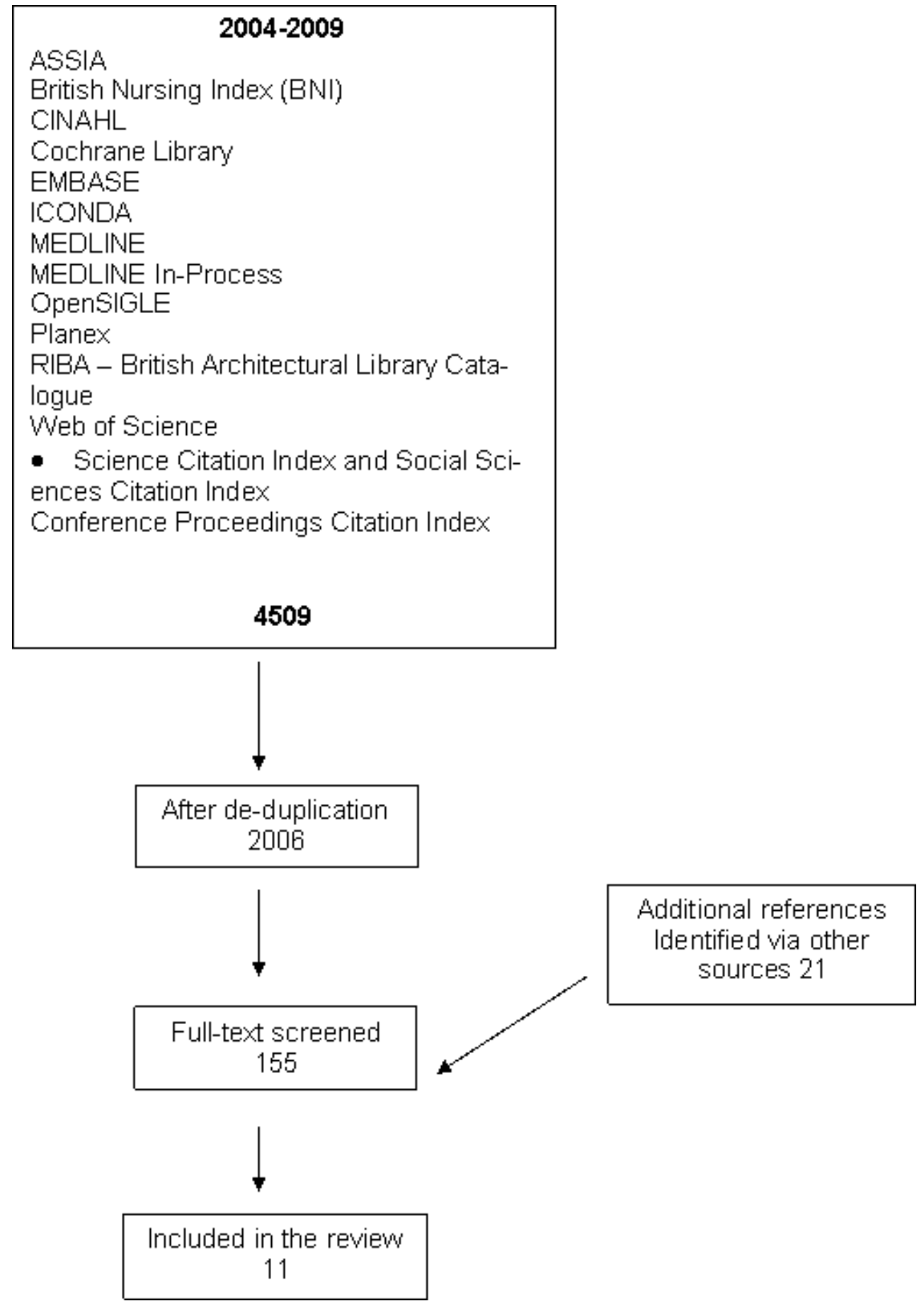




\section{Searching other resources}

In addition, we contacted first authors of all included RCTs to ask if they were aware of any recently published, in-press or unpublished studies on the topic. We carried out handsearching for the most recent 12 months, May 2009 to May 2010, of issues of journals appearing twice or more in the papers considered for inclusion.

- Age and Ageing

- BMC Public Health

- British Medical Journal

- Environmental Research

- Injury Prevention

- Journal of the American Geriatrics Society

- Pediatrics

We also checked the reference lists of systematic reviews for further studies relevant to modification of the home environment with a focus on interventions to modify environmental hazards.

This resulted in 21 additional references not found via the electronic search (see Figure 1).

\section{Data collection and analysis}

\section{Selection of studies}

Two authors pre-screened all abstracts for relevance, duplication, outcome and design. An expert assessor independently reviewed all abstracts considered not eligible. Where it was not possible to determine if a study met the inclusion/exclusion criteria on the basis of the title and/or abstract alone, we retrieved the full reference and two authors assessed the study according to the predefined inclusion/exclusion criteria. We also screened the reference lists of review articles for any additional studies.

\section{Data extraction and management}

Eligible studies were separated into three categories for the purposes of data extraction: a) older people, b) children and c) the general population. Two expert authors independently extracted data from each study. We used EPOC (data collection checklists) guidelines for methodological quality for quality checking and assessed inter-rater reliability by the kappa statistic. The kappa statistic for the older people category was 1 in the original review, 0.93 in the last update and 0.85 in the current update. It was 0.95 between raters for groups b) children and c) the general population in the original review, 1 in the update and 1 in the current update. We resolved any disagreements on data extraction by consensus discussion, following review by a third assessor.

\section{Assessment of risk of bias in included studies}

We considered allocation concealment to be adequate if the randomisation process was protected before and until allocation of treatment group (e.g. use of sealed opaque envelopes). Where a study reported randomisation, but did not describe the method of randomisation, or we judged the method described inadequate, we then deemed it to be a controlled clinical trial (CCT) and excluded it. We also assessed blinding of outcome assessment, method of analysis (e.g. Intention-To-Treat versus Per Protocol analysis), attrition rate and statistical power as indicators of study quality.

\section{Measures of treatment effect}

We performed meta-analysis by combining outcome measures and presented results using risk ratios (RR) and $95 \%$ confidence intervals $(\mathrm{CI})$.

\section{Assessment of heterogeneity}

We determined clinical and methodological heterogeneity by assessing the differences between study characteristics (e.g. variability in participants, interventions, outcomes, follow-up length, biases). If two or more studies were considered to be sufficiently homogenous, we explored variability between effect size using both the $\mathrm{Chi}^{2}$ test and the $\mathrm{I}^{2}$ statistic. $\mathrm{Chi}^{2}$ tests with a $\mathrm{P}$ value $\leq 0.10$ were taken as indicating significant statistical heterogeneity and I ${ }^{2}$ of $\geq 75 \%$ indicating a high level of heterogeneity.

\section{Data synthesis}

Although the studies included in this review reported a wide range of outcomes, we judged only two studies reporting falls as an outcome sufficiently methodologically and statistically homogenous to combine in a meta-analysis.

We performed all analyses using Review Manager software ( RevMan 2008). We used a random-effects model to adjust for the observed statistical heterogeneity between studies.

\section{RES U L T S}

\section{Description of studies}

See: Characteristics of included studies; Characteristics of excluded studies. 


\section{General findings}

In the initial searches performed up to December 2004, we identified 44,717 unique citations through our electronic database searches. A stepped exclusion exercise was performed where references were excluded on the basis of title or title and abstract based on the pre-defined inclusion/exclusion criteria. Where it was not possible to confirm inclusion/exclusion criteria on review of the abstract alone, we retrieved the full reference. At this stage, we identified 128 potentially relevant references. We identified three more studies through personal contact (Elkan 2000; Thomson 2001; Day 2002) and 13 additional citations by checking the reference lists of reviews (including one review article (Purdue 2003) which identified no new citations). Of the 144 studies reviewed in full, 19 met the inclusion criteria (Becker 2003; Carter unpublished; Clamp 1998; Close 1999; Cumming 1999; Day 2002; Gielen 2002; Hogan 2001; Jenson 2002; Kendrick 1999; King 2005; Nikolaus 2003; Pardessus 2002; Posner 2004; Shaw 2003; Stevens 2001; Tinetti 1994; Van Haastregt 2000b; Vetter 1992).

From our updated electronic searches, we found 2,006 unique citations, 155 of which we identified as potentially relevant citations. We retrieved only 152 studies in full, as one study was available only as an abstract (Rehmani 2005) and two studies were found to be duplications (Posner 2004; Watson 2005). In addition, we identified 21 more citations by checking the reference lists of systematic reviews. Of 173 studies reviewed in full, 10 additional studies met the inclusion criteria (Babul 2007; Campbell 2005; Elley 2008; Gitlin 2006; Hendrickson 2005; Hendriks 2008; Mahoney 2007; Salminen 2009; Sangvai 2007; Watson 2005). Therefore we have included 28 published studies and one unpublished study in this update.

\section{Excluded studies}

Initially, 87 studies appeared to meet the eligibility criteria, but after further inspection we excluded them as they did not meet all of the inclusion criteria. One (Ozanne-Smith 2002) was an ecological study where the measures of changes to physical hazards were not reported at household level, one (Assantachai 2002) was similarly community-based with no home hazard intervention, one (Duff 2002) included undefined access to home equipment with no measure of change to physical hazards and one (Swart 2008) did not meet the inclusion criteria definition for $a$ home. Seventeen studies (Caplan 2004; Bouwen 2008; Ciaschini 2009; Fergusson 2005; Haynes 2003; Huang 2003; Kerse 2004; Lannin 2007; Llewellyn 2003; Minkovitz 2010; Nelson 2005; Neno 2008; Neyens 2009; Ramsey 2003; Vind 2009; Weatherall 2004; Wyman 2007) had no intervention which met the inclusion criteria and two (Pressley 2009; Tanner 2003) had no outcome.

A further 13 studies were observational studies with either cohort, case-control or cross-sectional designs. One was a Germanlanguage paper that was found not to meet the inclusion criteria when it was translated. In another the environmental intervention was not taken up. Four studies were interrupted-time series studies that did not have a sufficient number of gathering points to meet the EPOC guidelines. One was a non-controlled before-and-after study, three were controlled before-and-after studies with no allocation concealment, one a PRECEDE-PROCEED model with different subjects and methods (Durongritichai 2003). Twentyseven (including Huang 2004; Lightbody 2002; Lin 2007; Peel 2000; Robson 2003; Sznajder 2003; Xia 2009) were considered controlled clinical trials because the method of randomisation was not adequately described.

Three studies did not focus on reducing acute physical injuries (Binns 2004; Boreland 2006; Gillespie-Bennett 2008), two were evaluation studies examining either a tool used in the study (Morgan 2005) or part of the methodology (Robertson 2005), three had smoke alarm installation as the sole intervention (Ginnelly 2005; Roberts 2004; Yang 2008), two were survey studies (Iwarsson 2009; Lamb 2008), two were protocols for studies (Kendrick 2008; Peeters 2007) and one was a Trial of Improved Practices (TIPs) methodology (Barnes 2004).

\section{Included studies}

We included 28 completed RCTs published between 1979 and the end of 2009 (Becker 2003; Babul 2007; Campbell 2005; Clamp 1998; Close 1999; Cumming 1999; Day 2002; Elley 2008; Gielen 2002; Gitlin 2006; Hendrickson 2005; Hendriks 2008; Hogan 2001; Jenson 2002; Kendrick 1999; King 2005; Mahoney 2007; Nikolaus 2003; Pardessus 2002; Posner 2004; Salminen 2009; Sangvai 2007; Shaw 2003; Stevens 2001; Tinetti 1994; Van Haastregt 2000b; Vetter 1992; Watson 2005) and one unpublished (Carter unpublished) study. Twenty studies were in older age groups and nine in child populations.

\section{Participants}

Study populations included: urban, suburban and rural families (including families in inner-city, lower-income areas) with children under five years; caregivers of children under five; parents of newborn infants; independent community-dwelling older people; staff of nursing homes; venues for older people; nursing home residents and in-patients of geriatric wards who had returned home; older people with visual acuity problems, cognitive impairment or functional vulnerability; emergency department patients; primary care patients; children from nursery and toddler groups; children attending secondary care paediatric clinics and specialist physicians in training. We also included census tracts and municipalities.

Cluster randomised trials included units based on general practices and residential care facilities for older people.

\section{Type of intervention}


- Two of the 29 RCTs made an environmental modification to the domestic environment as the sole intervention (Cumming 1999; Pardessus 2002).

- Seven studies used a combined approach of direct or recommended modification and educational strategy (Carter unpublished; Clamp 1998; Close 1999; Gielen 2002; Kendrick 1999; King 2005; Stevens 2001).

- Three studies used a combined approach of recommended modification with free safety devices, which in some cases were only available to low-income families, and an educational strategy (Hendrickson 2005; Posner 2004; Watson 2005).

- One study used a combined approach of recommended modification with free safety devices (Babul 2007).

- One study used a combined approach of free safety devices and safety counselling (Sangvai 2007).

- Thirteen of the studies (Becker 2003; Elley 2008; Gitlin 2006; Hendriks 2008; Hogan 2001; Jenson 2002; Mahoney 2007; Nikolaus 2003; Salminen 2009; Shaw 2003; Tinetti 1994; Van Haastregt 2000b; Vetter 1992) were multifactorial and included home modification for injury prevention as well as interventions that did not fit the review protocol. The other interventions encompassed the targeting of nutritional deficiencies, balance and resistance training, psychosocial activities, energy conserving techniques, training in use of mobility aids, exercise, medication review, visual problems, hip protectors, post fall problem solving conferences and reviews of medical conditions.

- Two of the studies (Campbell 2005; Day 2002) had a factorial design, which enabled the effect of each component to be evaluated separately, as well as any possible interactive effects between interventions to be examined.

All of the interventions, except two (Clamp 1998; Posner 2004), included a home assessment evaluation made by either a community nurse, trained researcher, project assistant, occupational therapist, health visitor or self-report by participant. Environmental hazards were evaluated using standardised data collection forms, structured interviews, questionnaires and checklists. Modifications to the home environment included the installation of grab bars, stair gates, handrails, fire guards, blind cord wind-ups, smoke alarms, cupboard locks, corner cushions for sharp-edged furniture, electric outlet covers, the reduction of hot water temperatures, the repair of damaged flooring, improvement in lighting levels and the stabilisation of floor surfaces. Fourteen of the interventions (Babul 2007; Campbell 2005; Clamp 1998; Day 2002; Elley 2008; Gitlin 2006; Hendrickson 2005; Kendrick 1999; King 2005; Mahoney 2007; Posner 2004; Sangvai 2007; Stevens 2001; Watson 2005) provided or made available free or discounted safety equipment or devices.

Interventions were delivered in either a healthcare setting (Posner 2004), in the clinical setting as part of routine health surveillance (Clamp 1998; Kendrick 1999; Sangvai 2007), the home (Babul 2007; Becker 2003; Campbell 2005; Carter unpublished;
Close 1999; Cumming 1999; Day 2002; Elley 2008; Gitlin 2006; Hendrickson 2005; Hogan 2001; Jenson 2002; King 2005; Mahoney 2007; Nikolaus 2003; Stevens 2001; Tinetti 1994; Van Haastregt 2000b) or in both a healthcare setting and the home (Day 2002; Gielen 2002; Hendriks 2008; Pardessus 2002; Salminen 2009; Shaw 2003; Vetter 1992; Watson 2005).

\section{Outcomes}

Sixteen of the 29 randomised controlled trials had an injury, or proxy for injury severity, such as seeking medical advice following a fall, as an outcome variable (Becker 2003; Campbell 2005; Carter unpublished; Close 1999; Elley 2008; Hendriks 2008; Jenson 2002; Kendrick 1999; King 2005; Salminen 2009; Sangvai 2007; Shaw 2003; Stevens 2001; Van Haastregt 2000b ; Vetter 1992; Watson 2005). Nineteen of the studies collected data on falls ( Becker 2003; Campbell 2005; Carter unpublished; Close 1999; Cumming 1999; Day 2002; Elley 2008; Hendriks 2008; Hogan 2001; Jenson 2002; Mahoney 2007; Nikolaus 2003; Pardessus 2002; Salminen 2009; Shaw 2003; Stevens 2001; Tinetti 1994; Van Haastregt 2000b; Vetter 1992). Fourteen studies collected data on hazard modification, which included the collection of data on safety knowledge and or possession, use and compliance of safety equipment, as an outcome (Carter unpublished; Clamp 1998; Cumming 1999; Day 2002; Gielen 2002; Gitlin 2006; Hendrickson 2005; King 2005; Nikolaus 2003; Posner 2004; Sangvai 2007; Shaw 2003; Stevens 2001; Watson 2005).

Outcome measures were collected either via self report using fall diaries or calenders, health professional report for care facilities, or chart or medical record review.

\section{Risk of bias in included studies}

The adequacy of allocation concealment was evaluated for all studies using the EPOC checklist for RCTs. Where a study reported randomisation but did not describe the method of randomisation, or the method described was judged inadequate, it was then deemed to be a controlled clinical trial (CCT) and was excluded. Schulz 2000 argues that studies have shown that methodologically weak RCTs and inadequately reported RCTs yield biased results. Their earlier review (Schulz 1995) of 250 controlled trials from 33 meta-analyses in pregnancy and childbirth found that RCTs with inadequate or unclear allocation concealment gave larger estimates of treatment effects, $41 \%$ and $33 \%$ respectively on average, than trials which reported adequate concealment. Similar results were found for trials in digestive diseases, circulatory diseases, mental health, and stroke (Moher 1998).They found that trials that used inadequate or unclear allocation concealment gave on average $37 \%$ larger estimates of effect, than those using adequate concealment.

Allocation concealment was judged adequate in all 29 included studies. Nine studies (Clamp 1998; Close 1999; Cumming 1999; 
Gielen 2002; Kendrick 1999; Pardessus 2002; Stevens 2001; Tinetti 1994; Vetter 1992) used a table of random numbers and nine (Campbell 2005; Carter unpublished; Day 2002; Elley 2008; Hendriks 2008; Hogan 2001; Shaw 2003; Van Haastregt 2000b; Watson 2005) computer generation. Nine studies (Babul 2007; Becker 2003; Gitlin 2006; Jenson 2002; Mahoney 2007; Nikolaus 2003; Posner 2004; Salminen 2009; Sangvai 2007) used sealed envelopes. One (King 2005) used sealed envelopes mixed in an opaque container, sequentially numbered when withdrawn and then distributed in aliquots to each study site, and one used a coin toss by the child's mother (Hendrickson 2005).

Nine studies had sufficient statistical power to detect important effects as statistically significant and recorded power (Elley 2008; Gitlin 2006; Hendriks 2008; Mahoney 2007; Nikolaus 2003; Posner 2004; Salminen 2009; Shaw 2003; Watson 2005). Two studies appeared slightly underpowered. In one (Day 2002) the power calculation was stated as requiring a sample size of 1143 and achieved a sample size of 1107 and in another (Hendrickson 2005), a sample size of 80 mothers was required and 78 was achieved. In three it was reported that the study was underpowered. Babul 2007 stated that their study was underpowered to detect injury outcomes and was limited to examining trends. Similarly another study (Becker 2003) was underpowered to detect a significant difference due to a lower than expected number of hip fractures. Pardessus 2002 did not report a power calculation but concluded that the number of participants in their study $(n=60)$ was perhaps too small to detect a significant difference between the intervention and control in terms of rate of falls. Campbell 2005 and Jenson 2002 reported that they had carried out power calculations but did not state the number required to achieve this.

One study had large losses to follow-up (Sangvai 2007), thus results should be interpreted with caution.

Blinding of outcome assessment was stated in eight studies (Campbell 2005; Elley 2008; Gitlin 2006; Hendriks 2008; King 2005; Posner 2004; Salminen 2009; Sangvai 2007). Although allocation concealment was judged adequate in Jenson 2002 and Hendrickson 2005, they were non-blinded. Outcomes were selfreported by participants, except in the following eight studies (Becker 2003; Campbell 2005; Elley 2008; Gielen 2002; Hendrickson 2005; Hendriks 2008; Salminen 2009; Watson 2005). Loss to follow-up ranged from $0 \%$ to $91.5 \%$.

\section{Effects of interventions}

\section{Falls}

\section{a) OIder people}

There were 19 studies in the older people category (Becker 2003; Campbell 2005; Carter unpublished; Close 1999; Cumming
1999; Day 2002; Elley 2008; Hendriks 2008; Hogan 2001; Jenson 2002; Mahoney 2007; Nikolaus 2003; Pardessus 2002; Salminen 2009; Shaw 2003; Stevens 2001; Tinetti 1994; Van Haastregt 2000b; Vetter 1992) reporting falls data.

Many of the studies involved multifactorial interventions: that is the intervention consisted of multiple components, not just a single intervention. In 11 studies (Carter unpublished; Elley 2008; Hendriks 2008; Hogan 2001; Mahoney 2007; Pardessus 2002; Salminen 2009; Shaw 2003; Stevens 2001; Van Haastregt 2000b; Vetter 1992), no significant effect of the intervention on falls was found. In Carter unpublished, the proportion of participants who reported falling did not differ significantly between the control group (CG) and either of the intervention groups (IG): brief intervention (odds ratio (OR) $0.6,95 \% \mathrm{CI} 0.3$ to 1.1 ) and intensive intervention (OR $0.8,95 \%$ CI 0.4 to 1.4). Hogan 2001 combined a home visit to record hazards and falls prevention classes, and found no significant differences between the CG and IG in the cumulative number of falls ( 311 versus $241, \mathrm{P}=0.34$ ), having one or more falls $(79.2 \%$ versus $72.0 \%, \mathrm{P}=0.30)$ or in the mean number of falls ( 4.0 versus $3.2, \mathrm{P}=0.43$ ).

In Pardessus 2002, a home visit was performed post hospitalisation for a fall. The main intervention was the identification of environmental hazards and the recommendation of home modifications. Social support mechanisms were also addressed. There was no significant difference in fall recurrence between the IG and CG (mean number of fall recurrences IG $0.68 \pm 0.16$ vs CG $0.82 \pm$ $0.16)$. However the study may have been underpowered to detect an effect. Shaw 2003 was a multifactorial intervention where intention-to-treat analysis showed no significant difference between IG and CG in proportion of patients who fell during one year of follow up (RR 0.92, 95\% CI 0.81 to 1.05). Stevens 2001, which combined a home visit to assess hazards, free safety devices and an educational strategy, found that there was no significant reduction in the IG in the incidence rates of falls involving environmental hazards inside the home (adjusted rate ratio $1.11,95 \% \mathrm{CI} 0.82$ to 1.50 ) or the rate of falls inside the home (adjusted rate ratio 1.17, $95 \%$ CI 0.85 to 1.60 ).

Van Haastregt 2000b reported no effect in the IG for those who experienced at least one fall (OR 1.3, 95\% CI 0.7 to 2.1) while Vetter 1992 found that more falls without fracture occurred in the IG ( $23 \%$ versus $16 \%$, no CI stated), although it is unclear if this is statistically significant.

Elley 2008's programme of falls and fracture risk assessment and referral to appropriate community interventions, such as an exercise programme, was not significant in reducing falls in older people (incidence rate ratio $($ IRR $)=0.96$, CI 95\% 0.70 to 1.34 ). The authors suggested that low adherence to programme components and possible internal contamination may have reduced the effectiveness of this study. In addition, the study authors speculate whether multifactorial studies lessen the effectiveness of the individual components.

The multifactorial fall prevention programme in Hendriks 2008 
was based on an earlier programme carried out in the UK (Close 1999). However, unlike the UK study, which found favourable effects on the number of people experiencing a fall, the Hendriks 2008 study carried out in the Netherlands, found no effect on falls $(\mathrm{OR}=0.86,95 \% \mathrm{CI} 0.50$ to 1.49$)$. The study authors gave several possible explanations for this, including the suggestion that the extended implementation period of the fall prevention programme, in a Dutch healthcare as opposed to a UK healthcare setting, may have reduced the effectiveness of this programme.

Mahoney 2007's results demonstrated that a multifactorial model with referrals to existing medical care and services supported with monthly follow-up calls to encourage adherence, did not decrease falls in community dwelling older adults ( $R R$ 0.81, $\mathrm{P}=0.27$ ). However, nursing home days were fewer in the IG (10.3 versus 20.5 days, $P=0.04)$. The study authors suggest their intermediateintensity model, which relied on recommendations and referrals, may not provide enough direct intervention to be effective.

Salminen 2009's multifactorial fall prevention programme, which was based on individual risk analysis, did not reduce the incidence of falls in community dwelling older people with at least one previous fall, during a 12-month follow-up (IRR 0.92, 95\% CI = 0.72 to 1.19$)$. However, in subgroup analysis, significant interactions between subgroups and groups, both in the IG and CG, were found for persons with depressive symptoms $(P=0.006)$, number of falls during previous 12 months $(\mathrm{P}=0.003)$ and self-perceived risk of falling $(\mathrm{P}=0.045)$. The authors present several explanations for their results, including opportunistic recruitment; nonstringent inclusion criteria; and the possibility that their study may have been underpowered to detect a reduction in the incidence of falls.

Two studies (Elley 2008 and Salminen 2009) were considered sufficiently methodologically and statistically homogenous to undertake a meta-analysis (Analysis 1.1). Both studies included a multifactorial fall prevention intervention. The interventions comprised: home hazard assessment and modification; medication review and health and bone assessment; and exercise programme. Inclusion criteria and outcome assessment were also considered comparable and both control groups received basic guidance on fall prevention. Combining data from these two studies showed that a multifactorial fall prevention programme designed for older people who had fallen in the previous 12 months did not reduce the risk of falling (RR $1.09,95 \%$ CI 0.97 to 1.23 ).

In other multifactorial studies (Becker 2003; Jenson 2002; Nikolaus 2003; Tinetti 1994), although a significant reduction in falls was reported, the effect of environmental modifications was impossible to separate from other interventions. Although Becker 2003 reported the incidence density rate of falls per 1000 resident years was 2558 for the CG and 1399 for the IG, (RR 0.55, 95\% CI 0.41 to 0.73 ), this was a multifactorial intervention targeting falls in nursing homes. The authors agreed on a list of environmental hazard removal and prosthetic supports but admitted that the lack of validated scoring system for environmental factors as well as time differences for corrections, made the reporting of adherence to environmental corrections unfeasible. Thus any contribution of home modification to the intervention effect was impossible to quantify. Additionally, it was argued that seeing the effects of environmental adaptations, such as installing new floor surfaces, would take more time than allowed in the study.

Jenson 2002 was a multifactorial fall prevention programme including staff education, environmental adjustment, exercise, medication review, aids, hip protectors and post fall problem-solving conferences. Their intervention significantly reduced the number of residents who fell (RR $0.78,95 \%$ CI 0.64 to 0.96 ), total number of falls (IRR $0.6095 \%$ CI 0.5 to 0.73 ) adjusted for baseline factors), time to first fall (adjusted hazard ratio $0.66,95 \%$ CI 0.54 to 0.79 ) and number of femoral fractures (adjusted OR $0.23,95 \%$ CI 0.06 to 0.94$)$. In Nikolaus 2003's study the interventions included modification to the home environment and training in the use of mobility and technical aids. The IG had $31 \%$ fewer falls than the CG (IRR 0.69, 95\% CI 0.51 to 0.97 ). The intervention was most effective in a subgroup of participants who reported having had two or more falls during the year before recruitment into the study.

In Tinetti 1994, the adjusted IRR for falling in the IG compared with the CG was 0.69 (95\% CI 0.52 to 0.90 ).

In one study (Cumming 1999), a reduction in falls was observed in an intervention subgroup only, participants with a history of falls (RR 0.64, 95\% CI 0.50 to 0.83 ).

In Day 2002, the percentage estimated reduction in annual fall rate attributed to home hazard management was not significant (3.1\%, 95\% CI -2.0 to 9.7). However, there was a significant effect when the intervention included exercise $(9.9 \%, 95 \%$ CI 2.4 to 17.9). The strongest effect was observed when all three interventions; exercise, home hazard management, vision correction, were combined together $(14.0 \%, 95 \%$ CI 3.7 to 22.6 ), (RR $0.67,95 \%$ CI 0.51 to 0.88 ). The study authors propose that the intervention may not have been intensive enough or the modifications may not have been sufficient or the right type to affect falls outcome. Campbell 2005's study focused on older people with severe visual impairment. Due to the factorial design, each component of the study could be evaluated separately. They found that fewer falls occurred in the group randomised to receive only the home safety programme, compared to the social visits group (IRR 0.39, $95 \%$ CI 0.24 to 0.62 ).

There were no included studies which had falls data as an outcome measure in children or general population categories.

\section{Injuries}

\section{a) Older people}

There were 13 studies which included older people (Becker 2003; Campbell 2005; Carter unpublished; Close 1999; Elley 2008; 
Hendriks 2008; Jenson 2002; Nikolaus 2003; Salminen 2009; Shaw 2003; Stevens 2001; Van Haastregt 2000b; Vetter 1992) and reported injuries data, 11 of which found no significant reduction in the IG. In Becker 2003, no significant difference in hip fractures between the IG and CG (RR 1.11,95\% CI 0.49 to 2.51) was reported. There was also no significant difference between the incidence density rate of non-hip fractures between the IG and the CG (RR 0.78, 95\% CI 0.57 to 1.07). Similarly in Shaw 2003, the RR between the IG and CG was not significantly different for major injuries (RR 1.32, 95\% CI 0.87 to 2.00 ) or fractured neck of femurs (RR $0.55,95 \%$ CI 0.21 to 1.72 ). However in all of these studies the numbers of injuries were small. Nikolaus 2003 was not designed to examine fall-related injuries and stated that numbers were too small for statistical comparisons. Stevens 2001 found no significant reduction in the rate of injurious falls in the IG (adjusted RR 0.92, 95\% CI 0.73 to 1.14). Vetter 1992 reported a similar proportion of fractures in both the IG and CG (5\% versus $4 \%$, no CI stated). Van Haastregt 2000 b reported OR 1.4 (95\% CI 0.8 to 2.6 ) for injurious falls in the IG compared to the CG.

Five further studies (Carter unpublished Close 1999 Elley 2008; Hendriks 2008; Salminen 2009) found no significant reduction in the number of injurious falls or fracture rates. Carter unpublished found the proportion of participants who reported one or more falls requiring medical attention did not differ significantly between CG and either of the IGs: brief intervention (OR 0.7, 95\% CI 0.2 to 2.2 ) and intensive intervention (OR $0.7,95 \% \mathrm{CI} 0.2$ to 2.4). Close 1999 found no significant reductions in the percentage of patients reporting serious injury from falls (CG $8 \%$ versus IG $4 \%, P=0.26$ ). Elley 2008 reported no significant reduction in moderate injurious falls (IG 1.05 injurious falls per person-year vs CG 1.00, no CI stated) or serious injurious falls (IG 0.09 injurious falls per person-year vs CG 0.05 , no CI stated). The study authors speculate whether multifactorial trials lessen the effectiveness of the individual components. Hendriks 2008's study reported no significant reduction in injurious falls between IG and CG (OR $0.77,95 \%$ CI 0.35 to $1.73, \mathrm{P}=0.53$ ). Salminen 2009's intervention did not reduce the incidence of falls requiring medical treatment at 12 months' follow-up (IRR $1.04,95 \%$ CI 0.64 to 1.69 ) or at three years follow-up (IRR 0.87, 95\% CI $=0.63$ to 1.21 ).

The picture is only a little different in Jenson 2002. Although the authors report a reduction in injurious falls in the IG, no statistical comparison is reported. However, a significant reduction in femoral fractures is recorded, with only three residents in the IG suffering a femoral fracture compared to 12 in the CG (adjusted $\mathrm{OR}=0.23$, CI 0.06 to 0.94 ). In a later report, Jensen 2003 analysed the effect of this intervention in older people with differing levels of cognitive function. Fifty-nine minor, moderate or serious injuries occurred in the higher cognitive group, giving a non-significant crude IRR 0.90 (95\% CI 0.50 to 1.50) compared with the control group and similarly in the lower cognitive group (crude IRR 0.90, $95 \%$ CI 0.50 to 1.30 ). However in the lower cognitive group the
171 participants sustained 10 femoral fractures, all of which were in the control group (result expressed as $\mathrm{P}=0.006$ ).

In Campbell 2005's study, which focused on older people with visual acuity problems, a significant reduction in injurious falls was reported in the home safety programme only group versus social visits group (IRR $0.56,95 \%$ CI 0.36 to 0.87 ).

\section{b) Children}

Five studies (Babul 2007; Kendrick 1999; King 2005; Sangvai 2007; Watson 2005) reported data on injuries. Four of these studies found no significant difference in injury occurrence between IG and CG. Kendrick 1999 reported no significant change in the frequency of at least one medically attended injury (OR $0.9795 \%$ CI 0.72 to 1.30), at least one attendance at an accident and emergency department for injury (OR 1.02, 95\% CI 0.76 to 1.37 ), at least one primary care attendance for injury (OR 0.75, 95\% CI 0.48 to 1.17 ) or at least one hospital admission for injury (OR $0.69,95 \%$ CI 0.42 to 1.12 ). Sangvai 2007 's multifactorial intervention showed no significant difference in medically attended injuries (19/160 IG and 22/159 CG). Watson 2005 reported a higher attendance rate for injury in primary care in the IG compared to the CG (IRR $1.37,95 \% \mathrm{CI}=1.11$ to $1.70, \mathrm{P}=0.003$ ). Treatment arms did not differ significantly for other injury outcomes. Finally in Babul 2007 injury rates did not differ between the group provided with a safety kit and the CG (OR 1.03, 95\% CI 0.49 to 2.18 ), or the safety kit plus home visit group and CG (OR 1.05 , 95\% CI 0.50 to 2.21 ).

King 2005's study showed a significant reduction in injury visits per patient at 12 months in the IG (RR $0.69,95 \% \mathrm{CI}=0.54$ to 0.88). However, they reported that between 12 and 36 months the effect appeared to diminish but did not cause harm (RR 0.8, $95 \%$ CI 0.64 to 1.00 ).

\section{c) General population (mixed age groups)}

There were no included studies in the general population group.

\section{Hazards reduction (including safety knowledge, possession, compliance with and use of safety equipment)}

\section{a) Older people}

Eight included studies (Campbell 2005; Carter unpublished; Cumming 1999; Day 2002; Gitlin 2006; Nikolaus 2003; Shaw 2003; Stevens 2001) reported data on hazard reduction in older people. All eight studies found a greater reduction in hazards in the IG compared to the CG, but only two studies reported a significant reduction (Carter unpublished; Stevens 2001). Five studies did not report whether their result were statistically significant, 
and Gitlin 2006's results appeared non-effective. Only three studies (Campbell 2005; Cumming 1999; Nikolaus 2003) had an associated reduction in falls. In one other study (Day 2002), the reduction in falls could not be directly associated with the reduction in hazards.

In Nikolaus 2003, 222 home modifications were recommended. A minimum of one recommended change was implemented by 137 homes $(75.7 \%)$. The most commonly recommended changes were elevation of the toilet seat in 43 homes, use of a rollator (walking frame with wheels) in 37 homes and fixing grab rails in the bathroom in 27 homes. Compliance with recommendations ranged from $33.3 \%$ to $82.6 \%$ at 12 months' follow-up. Participants who made at least one of the recommendations experienced a significant reduction in the rate of falls (IRR $0.64,95 \%$ CI 0.37 to $0.99, \mathrm{P}=0.047$ ) at 12 months' follow up. The number of falls in participants in the IG with no home modifications was not significantly different from those in the CG (IRR 1.05, 95\% CI 0.82 to 1.41 ). Therefore an intention-to-treat analysis would be likely to report no difference between the groups. Cumming 1999 observed a reduction in hazards in the IG but it is unclear if this was a significant reduction and falls were only reduced in the intervention sub-group with a history of falls (RR 0.64, 95\% CI 0.50 to 0.83 ). In Campbell 2005, $85 \%$ of participants in the home safety group were followed up at six months (169/198), and $90 \%$ of these (152/169) were reported as complying partially or completely with one or more of the home safety recommendations made by the occupational therapist, implying that the intervention was acceptable.

Carter unpublished observed a positive effect on making changes to improve home safety in both IGs with $35 \%$ in the brief intervention group and $49 \%$ in the intensive IG making changes in the home to improve safety, compared to $28 \%$ in the CG at 12 months' follow-up. No test for statistical significance was reported. In Shaw 2003 there was no significant change in environmental risk factors score at three months in either the IG or CG, but there was a significant change in score between the two groups, $\mathrm{P}<0.001$. Stevens 2001 reported statistically significant improvements in a sample $(\mathrm{n}=51)$ of the larger study in: unsafe steps (Mean 0.61, $95 \%$ CI 0.28 to 0.94 ), stabilisation of rugs and mats (Mean 1.27, $95 \%$ CI 0.91 to 2.24 ), rooms with trailing cords (Mean $0.43,95 \%$ CI 0.10 to 0.76 ) and rooms with unsafe favourite chair (Mean $0.1095 \%$ CI 0.02 to 0.18 ). Whilst the authors reported other results as significant, no statistical significance tests were reported. Day 2002 reported that of the 543 participants receiving the home hazard management intervention, 478 were advised to have modifications to their homes. Help to carry out modifications was received by 363 participants which included 275 hand rails fitted, 72 modifications to floor coverings and 72 homes receiving contrast edging to steps. Modification of environmental hazards on their own did not reduce injuries but the strongest effect was found when all three interventions (exercise, medical review and home modification) were combined (RR $0.67,95 \%$ CI 0.51 to 0.88 ).
In Gitlin 2006's study, the effect of their intervention on environmental home hazards at 12 months was reported as a difference of adjusted means of $-1.38,95 \% \mathrm{CI}-3.17$ to $0.41, \mathrm{P}=0.13$, which is not statistically significant.

\section{b) Children}

Eight studies reported data on hazard reduction (Babul 2007; Clamp 1998; Gielen 2002; Hendrickson 2005; King 2005; Posner 2004; Sangvai 2007; Watson 2005) and seven reported either a significant reduction of hazards or significant increase in safety features in the IG. Clamp 1998 found that significantly more families in the IG used fireguards (RR 1.89, 95\% CI 1.18 to 2.94), socket covers (RR 1.27, 95\% CI 1.10 to 1.48 ), locks on cupboards for storing cleaning materials (RR $1.38,95 \%$ CI 1.02 to 1.88 ), and door slam devices (RR 3.60, 95\% CI 2.17 to 5.97) compared to the CG. In addition, significantly more families in the IG showed safe practice for windows (RR 1.30, 95\% CI 1.06 to 1.58 ), fireplaces (RR 1.84, 95\% CI 1.34 to 2.54 ) and door-slam safety (RR 7.00, $95 \%$ CI 3.15 to 15.6 ). King 2005 found a significant reduction in the prevalence of homes with hot water above $54^{\circ} \mathrm{C}$; (OR $1.31,95 \% \mathrm{CI} 1.14$ to 1.50$)$ and the presence of a fire extinguisher (OR 0.81, 95\% CI 0.67 to 0.97 ) in the IGs (King 2001). In one study (Posner 2004), the IG received comprehensive home safety education and free safety devices and the CG received a focused injury-specific emergency department discharge set of instructions. The IG demonstrated significantly higher average overall safety scores than the CG $(73.3 \%$, SD $8.4 \%, \mathrm{P} \leqq 0.002)$, and significant improvements in prevention of the following hazards: poison $(74.4 \%$, SD 19.5, $\mathrm{P} \leqq 0.02)$, cut/piercing ( $81 \%$, SD 18.2, $\mathrm{P}$ $\leqq 0.001)$ and burn category scores $(76.0 \%$, SD 14.9, P $=0.03)$. Caregivers in the IG also demonstrated greater improvement in reported use of the distributed safety devices $(65.4 \%$, SD 20.5, P $\leqq 0.001)$.

Three further studies (Babul 2007; Hendrickson 2005; Watson 2005) demonstrated a reduction in hazards. In Babul 2007, parents in both IG (home visit plus safety kit and just safety kit) were more likely to report having hot water at a safe temperature than CG participants: safety kit alone (OR 2.21, 95\% CI 1.32 to 3.69); and safety kit plus home visit (OR 2.6, 95\% CI 1.57 to 4.46), both adjusted for income and baseline measure of dependent values. Parents receiving the safety kit plus home visit were also more likely to report having used the hot water temperature-testing card than those receiving the safety kit alone (OR 2.38, CI 1.42 to 3.97, adjusted for income), and compared to the CG, were more likely to report having plants placed out of reach of children (OR 1.90, 95\% CI 1.03 to 3.52, adjusted for income and baseline measure of dependent values), as some houseplants are toxic.

In Hendrickson 2005 a statistically significant difference was found in controllable safety hazard scores between groups $(\mathrm{F}(1.77)$ 99.6, $\mathrm{P} \leqq 0.01)$. In Watson 2005, at both one-year and two-year follow-up, families in the IG were significantly more likely to have 
implemented a range of safety practices. At 12 months' follow-up the IG were significantly more likely to be safe in terms of smoke alarms (OR 1.83, CI 1.33 to $2.52, \mathrm{P}=0.0002$ ), stairs (OR 1.46, CI 1.19 to $1.80, \mathrm{P}=0.0004$ ), windows (OR 1.28 , CI 1.02 to $1.59, \mathrm{P}=0.03$ ), storage of cleaning products (OR 1.34, CI 1.09 to $1.66, \mathrm{P}=0.006$ ) and sharp objects (OR 1.34, CI 1.09 to 1.65 , $\mathrm{P}=0.005$ ) in the kitchen than families in the CG. At 24 months' follow-up, families in the IG were also significantly more likely to be safe in terms of smoke alarms (OR 1.67, CI 1.21 to 2.32, P = 0.002 ), storage of medicines (OR 1.55 , CI 1.00 to $2.40, \mathrm{P}=0.05$ ), and cleaning products (OR 1.31, CI 1.07 to $1.60, \mathrm{P}=0.008)$ in the kitchen than families in the CG. However, absolute differences in the percentages of families with safety practices were small. For example in the case of fitted window locks, $71.7 \%$ of families in the IG were reported as having locks at follow-up compared to $66.5 \%$ in the CG.

In Sangvai 2007, smoke detectors were functional in 16 of 17 intervention households compared with five of 10 control households ( $\mathrm{P}=0.015$, fisher exact test), and hazardous substances were not found in low cabinets of 13 of 16 intervention households compared to three of 10 control households ( $\mathrm{P}=0.015$, fishers exact test). However results should be interpreted cautiously due to large losses to follow-up.

Gielen 2002 randomised participants to either a standard or an enhanced-intervention group. Parents in the standard-intervention group received safety counselling and referral to a childrens safety centre; parents in the enhanced-intervention group received these standard services plus a home visit. No significant differences in safety practices were observed between study groups. However, a sub-analysis, independent of study group, found that families who visited the safety centre were significantly more likely to have 3 or more home safety practices observed, compared to families who did not (34\% vs $17 \% \geq 3$, OR 3.39, $95 \%$ CI 1.30 to 8.82$)$. Although this analysis was adjusted for exposure to safety counselling and a home visit, and the authors found no socio-demographic confounders; it was based on non-randomised participants and is therefore susceptible to confounders and self selection bias.

\section{c) General population (mixed age groups)}

There were no included studies in this group.

We did not contact authors of included studies for further information or data.

We have included supplementary results data in the Additional tables (Table 1; Table 2).

\section{DISCUSSION}

It is logical to presume that the presence of environmental risk factors must play some part in the cause of injuries in the home.
However, despite the inclusion of 29 randomised trials, the findings of this review suggest that there is little high-level scientific evidence for modification of the built home environment as a method of reducing the risk of injury. It should be remembered that only some home injuries are due to environmental hazards and that removal of such hazards or provision of safety equipment can only influence the occurrence or severity of these particular injuries. As most studies reported all injuries as their outcome, this will have the effect of reducing the power to detect changes in falls and injuries due to environmental hazards. Most studies did not provide enough detail in their results to ascertain the mechanism of injuries, probably as such information was not available to them and is difficult to systematically collect from participants or routine data sources.

\section{Summary of the main findings}

Thirteen of the studies in the older people group reported injuries as an outcome. However, only two of these studies reported a significant reduction in injuries (Campbell 2005; Jenson 2002). Campbell 2005 reported significantly fewer injurious falls in the intervention group (IG) compared to the control group (CG) (IRR $0.39,95 \%$ CI 0.24 to 0.62 ) and Jenson 2002's study found a significant reduction in femoral fractures in the IG (adjusted OR $0.23,95 \%$ CI 0.06 to 0.94 ) but no reductions in falls that resulted in minor or moderate injuries. Campbell 2005 used a $2 \times 2$ factorial study design, and specifically targeted interventions towards older people with severe visual impairment, which may mean the results from this study are not generalisable to other populations. The home safety intervention was delivered by an occupational therapist and included a home safety assessment and modifications to the home environment if indicated. In contrast, Jenson 2002's study was set in a residential care facility in Sweden, and used an 11-week multifactorial programme which included general and individualised strategies focusing on: educating staff; modifying the environment; implementing exercise programmes; medication reviews and providing free hip protectors. Campbell 2005 's factorial study design allowed the home safety programme to be evaluated in isolation and potentially permits a direct link to be made between the home safety programme and subsequent reduction in injuries. This is not possible in Jenson 2002's study due to their multifactorial study design. Jenson 2002 also stresses that no femoral fractures occurred in residents wearing hip protectors and suggest that their use may have contributed towards this result. When comparing results across studies, it should be considered that hazard prevalence and other risk factors for having a fall or injury vary by setting and hence variation in effect sizes of interventions is to be expected.

Out of the nine studies involving children, five reported injuries as an outcome. Only one of these studies reported significantly fewer self-reported injuries in the IG (King 2005) at 12 months' follow-up (RR 0.69, 95\% CI 0.54 to 0.88 ) and a borderline result 
at 36 months' follow-up (RR $0.8,95 \%$ CI 0.64 to 1.00 ). None of the studies involving children reported a significant reduction in medically attended injuries. King 2005's study was aimed at children under eight years old, and intervention participants received a single home visit that included an information pack, discount coupons, and specific instructions regarding home safety measures. Interestingly, out of the 16 safety modifications, only hot water temperature was shown to be significantly lower in the intervention households (OR 1.31, 95\% CI 1.14 to 1.50).

In an earlier report (King 2001), the actual observation of hazard changes was at variance with the self-reported adoption of safety precautions. The authors conclude that it is unlikely that the intervention had an impact on the adoption of home safety measures and that other effects of the intervention, such as behavioural changes, might explain the reduction in injuries.

\section{Key themes and relevance of evidence}

Although the focus of this systematic review is on the prevention of injuries by modifications of the home environment, most of the studies focusing on older people used the incidence of falls rather than the rate of injuries as their main outcome measure. Although the majority of fractures in older people follow a fall, only around one in 20 falls leads to a fracture (Rubenstein 2001). A reduction in the proportion of people in an IG suffering a fall should lead to a similar reduction in the proportion suffering a fracture, but the absolute number of fractures prevented will be much smaller. Studies using fracture incidence as their endpoint would need to be very much larger in scale, and this explains the literature's focus on fall prevention. There is no doubt that falls and the fear of falling are significant public health problems in themselves, but one cannot automatically assume that success in a falls prevention strategy will necessarily be reflected in reduced rates of injuries or fractures.

Additionally the vast majority of these studies were multifactorial and the effect of home modification on falls was either inseparable or insignificant. However this is a problem posed by the fact that falls, injuries or fractures in older people are commonly multifactorial in origin. A child may suffer a fracture that reflects the severity of the trauma, but over $95 \%$ of fractures in older people occur after only minor or moderate trauma (Johansen 1999). Factors underlying the causes of falls or the reduced ability to react and cushion the impact, and those affecting bone fragility are all relevant to the occurrence of injuries in older people.

Environmental modification cannot address all of these factors and injury prevention studies in older people therefore tend to be multifactorial in nature. This makes it more difficult to distinguish the contribution of environmental modification to the effectiveness of any strategy. An example of this is Nikolaus 2003 who found $31 \%$ fewer falls in the IG than in the CG however the intervention also included training in the use of technical and mobility aids. However, participants who made at least one of the home modifications at 12 months' follow-up did experience a significant reduction in the rate of falls (IRR $0.64,95 \%$ CI 0.37 to $0.99, \mathrm{P}$ $=0.047)$. In contrast, Day 2002 used a rigorous factorial design where the separate and combined effects of exercise training, vision improvement and house hazards management on falls could be assessed. Although the study reported non-significant reductions in falls following home hazard management as a sole intervention, when combined with both of the other interventions positive additive effects were reported. However, the beneficial effects were only significant when the combination of interventions contained an exercise component.

Studies in this review tended to be conducted in areas, countries or settings where the major environmental hazards have already been removed. Studies in low and/or middle income countries (LMICs) were largely absent from the literature and this may reflect issues in funding this type of study in these settings. Our selection criteria, which excluded housing which was not subject to housing regulations, also meant that studies conducted in potentially more hazardous environments were unlikely to be included. Given this, only modest changes may be possible in settings where the major environmental hazards have already been removed. Furthermore the fact that only a proportion of all falls or injuries can be addressed by additional environmental changes means that many studies which were powered to detect changes in all falls or injuries suffer from low statistical power when the outcome of interest is falls or injuries associated with hazards. Most trials with the prevention of injuries as an outcome require large numbers using all injuries as an outcome and it may not be feasible to fund or implement adequately powered studies to detect modest changes in injuries due to modification of specific environmental hazards. Campbell 2005's study was the only study to demonstrate a direct association between the home safety component of the intervention and a significant reduction in falls. However, the authors reported that there was no significant difference between falls occurring inside and outside the home, where the home modification intervention could not have influenced the risk of falling. This result has also been reported in other studies (Cumming 1999 and Nikolaus 2003) and led Campbell 2005 to suggest that the reduction in falls may have been due to a combination of the occupational therapist's fall prevention advice as well as the environmental modifications in the home.

A number of studies involving older people reported a reduction in home hazards which did not translate into a reduction in falls or injuries (Carter unpublished; Shaw 2003; Stevens 2001). Further, several studies reported no significant reduction in injuries, falls or hazards (Elley 2008; Gitlin 2006; Hendriks 2008; Hogan 2001; Mahoney 2007; Pardessus 2002; Salminen 2009; Van Haastregt 2000b; Vetter 1992). The authors suggest several possible explanations for the ineffectiveness of their studies.

Mahoney 2007 speculated that low intensity interventions which rely upon recommendations and referrals may be too indirect to be effective, but that financial constraints may prevent the successful 
implementation of higher intensity fall prevention programmes. Mahoney 2007's study demonstrated that telephone follow-up alone is not necessarily efficacious in increasing the effectiveness of an intermediate multifactorial study based upon recommendations and referrals.

There is also a debate as to whether multiple or single factor fall prevention programmes are more effective. Although meta-analyses have shown that multifactorial fall prevention programmes reduce the number of falls (Chang 2004; Campbell 2007), a recent meta-analysis found that the number of people having at least one fall did not reduce significantly in multifactorial interventions and that the benefit of multifactorial programmes may be less than first thought (Gates 2007). In addition, a meta-analysis of two studies carried out in our review found a multifactorial fall prevention intervention including home assessment and modification, medication review and health and bone assessment, and an exercise programme to be ineffective at reducing falls in older people (RR $1.09,95 \%$ CI 0.97 to 1.23$)$. Many authors have proposed that multiple component interventions may act to lessen the impact of their individual components (Elley 2008; Salminen 2009) and Campbell 2007 has shown that multifactorial programmes may lead to lower adherence rates in some part or parts of the intervention.

Campbell 2005 found that participants who received a combined intervention of home safety and exercise were more likely to fall or suffer an injurious fall than those who received only the home safety programme. The fall rate was also found to be greater in participants who received the exercise programme compared to the CG, albeit not significantly. The results of this study are in stark contrast to the results of Day 2002 which found the exercise component of their factorial study to be the most effective at reducing falls. Campbell 2005 concluded that although the Otago exercise programme has been shown to be successful in other populations (Campbell 1997; Robertson 2001; Robertson 2001a), in a population of older people with severe visual impairment, the programme may be unsuitable and potentially harmful.

Hendriks 2008's study highlighted the potential impact a different health care setting can have on the outcomes of a fall prevention programme. Hendriks 2008 based their programme on a multifactorial fall prevention study that had been carried out in the UK (Close 1999). However, unlike the UK study which found the programme to have significantly beneficial effects on the number of participants experiencing a fall (Close 1999), the Hendriks 2008 study, which was carried out in a Dutch healthcare setting, reported no statistically significant effect on falls. Although the authors provide several possible theories for the ineffectiveness of their study, they emphasise that the adaptations to the protocol which were required to implement the programme into the Dutch healthcare setting may have been one of the main causes. By introducing two new professional disciplines into the study (rehabilitation physician and geriatric nurse) and by involving GPs, the implementation period was extended by approximately 3.5 months.
The study authors suggest that the extended time period between fall and completion of the intervention, may have reduced the efficacy of the programme in this healthcare setting.

It is also possible that a number of the multifactorial studies were underpowered to detect a statistically significant difference. An earlier meta-analysis suggested that a $30 \%$ relative reduction in falls was an attainable result for a multifactorial fall prevention programme (Chang 2004). However a more recent meta-analysis reported that a smaller relative reduction, approximately 10 percent, might be expected (Gates 2007). A number of studies including Salminen 2009 calculated their sample size based on a $30 \%$ difference and therefore these studies may have been underpowered to detect a $10 \%$ reduction in falls.

Nonetheless multifactorial fall prevention programmes have demonstrated positive results. One of the first successful fall prevention studies used a multifactorial design (Tinetti 1994) and Jenson 2002, a multifactorial study set in a residential care home, reported significant reductions in falls and femoral fractures in the IG.

Overall there were nine included studies involving children (Babul 2007; Clamp 1998; Gielen 2002; Hendrickson 2005; Kendrick 1999; King 2005; Posner 2004; Sangvai 2007; Watson 2005). Although King 2005 reported a significant reduction in self-reported injuries in the IG, they found that a single home visit was insufficient to encourage a lasting adoption of home safety measures. King 2005 concluded that a successful home visitation programme may require several home visits in order to develop a more therapeutic relationship with the participant, so that wider issues which may affect a child's safety can be addressed. Watson 2005 unexpectedly found a significant increase in primary care attendances in the IG, even though the prevalence of safety practices in this group was significantly increased compared to the CG. As well as proposing possible explanations for this result, Watson 2005's study highlights the difficulties in demonstrating a reduction in injuries using RCT's. As the prevalence of safety features is high and the incidence of injuries that could be prevented from these safety features is low, very large sample sizes are usually required. One alternative offered by Watson 2005's study is to conduct well designed case-control or cohort studies to examine the effect of safety equipment followed by RCTs to investigate strategies for the increased uptake of effective safety equipment. Hewitt 2008 challenges this approach, arguing that observational studies are potentially biased and this is why we conduct randomised trials. Specifically they assert that Watson 2005's result indicates potential for harm caused by the intervention.

Five studies (Clamp 1998; Gielen 2002; Gitlin 2006; Hendrickson 2005; Posner 2004) in this review assess a change in safety features or hazards without reporting injury occurrence. Whilst it is logical to deduce that physical hazards in the home will contribute to a sequence of events culminating in an injury, it is not possible to conclude that the modification of such hazards will definitely reduce the number of injuries. However, even though a direct 
association can not be made between hazard reduction and injury reduction, the three studies which reported a significant reduction in hazards (Clamp 1998; Hendrickson 2005; Posner 2004) can be viewed encouragingly.

Although Sangvai 2007 reported significant reductions in hazards in the IG, the very large losses to follow-up may have been a potential source of bias. The more enthusiastic participants who implemented the home safety intervention more effectively may have been more likely to agree to a follow-up home visit. This may have led to an over-estimation of the effectiveness of this intervention.

Although Gielen 2002 found no significant difference in safety practices between study groups, an adjusted sub-analysis revealed families who visited the safety centre were significantly more likely to have 3 or more safety practices compared to families who did not $(34 \%$ vs $17 \% \geq 3)$. However these results should be interpreted with caution, given the analysis was based on non-randomised participants. The study authors mentioned that during the home visit safety products were not installed due to concerns around liability. Other studies which have since obtained liability waivers and installed safety products have been shown to be more successful (King 2005).

It is worth noting that there are currently no RCTs included in the mixed age group. A controlled clinical trial by Petridou 1997 included only 172 households and 636 people in the IG. Significant improvement in the provision of automatic electricity cut off devices and better lighting in corridors as well as first aid kits were reported post intervention but there were no changes in structural or expensive interventions, for example, modification to stairs or balconies. A non-significant $21 \%$ reduction in home injuries was reported (95\% CI $-40 \%$ to $+6 \%$ ).

\section{Meta-analysis issues}

Attempting to carry out meta-analyses with the studies included in this review proved to be problematic. The majority of studies included were too methodologically and statistically heterogenous to combine the results. Specifically, studies varied in terms of the characteristics of the population, inclusion and exclusion criteria and components of the intervention. Populations varied in terms of age, cognitive function and physical ability. Inclusion and exclusion criteria differed inasmuch as studies might include only those who had had a previous fall, attended the emergency department or been admitted to hospital after a fall. This may mean that populations in these studies could be considered at higher risk of falling and thus results might be less generalisable. Components of the interventions differed greatly. Participants might be visited at home or not, safety equipment might be free, means tested, directly supplied or referral made to a service where it could be obtained. Medication reviews were sometimes carried out, exercise programmes might be included and, if so, provided directly or referred to a programme. In some studies direct assistance with hazard modi- fication might be provided or advice only given. Outcomes also differed. These included falls, injurious fall, fractures, self reported injuries and medically attended injuries. When studies appeared methodologically similar and combining data appeared plausible, we attempted meta-analysis. In the end only one meta-analysis was included in this review, as the other attempted analyses were too statistically heterogeneous.

\section{Conclusion}

The conclusion of this systematic review is that there is very little high-grade evidence that interventions to modify the home physical environment affect the likelihood of sustaining an injury in the home.

The first version of this review included 28 studies (13 RCTs, 14 CCTs and one before-and-after study). The 2006 update identified six additional RCTs which allowed the inclusion criteria to be limited to higher quality randomised controlled studies. In this update we identified a further 10 RCTs. However this review still does not provide a clear, unequivocal evidence base that modification of the home environment reduces injuries. None of the studies focusing on children demonstrated a reduction in injuries that might have been due to environmental adaptation in the home; one study reported a reduction in injuries and hazards but the two could not be directly associated. Of the 20 included studies in the older people category, none demonstrated a reduction in injuries that could be directly linked to hazard reduction, although two demonstrated a reduction in falls that may have been due to environmental hazard reduction in the home. This is not the same as saying that such interventions are ineffective. It should be remembered that many of the studies in this review were powered to detect changes in all falls and injuries. Therefore it is likely that these studies were under-powered to detect a change in falls and injuries that occurred specifically as a result of an environmental hazard in the home. In addition, it is often difficult to fund studies which focus on the prevention of injuries as an outcome, as large numbers of participants are often required for the study to be adequately powered. The studies in this review also tended to be conducted in areas where the major environmental home hazards had already been removed, making it possible for only modest changes in the environment to be observed. It is also important to highlight that, due to the stringent exclusion criteria for this review, studies may have been excluded where allocation concealment was carried out but not reported adequately in the methodology.

Although the debate surrounding the effectiveness of multifactorial interventions continues, they have been shown to be effective at reducing falls (Day 2002; Becker 2003; Jenson 2002; Nikolaus 2003; Tinetti 1994). It is important however to know the cost-effectiveness of specific components of multifactorial interventions, so that scarce resources can be targeted to the most effective interventions. In order to answer these questions, future studies should 
adopt a factorial design and have sufficient power to detect modest, but important, changes in injury occurrence.

\section{Limitations of the review}

Publication bias can threaten the validity of systematic reviews if research which does not reach statistical significance or produces a counter-intuitive result is not published. We searched a large number of electronic databases covering health, social science and architectural domains. Although we contacted first authors of all included studies, we did not contact lead researchers in this update to ask about unpublished material, as in the first review it had a very low yield and was resource intensive. We cannot rule out the possibility, therefore, of missing studies published in journals not indexed in the electronic databases and which have not been referenced in any of the included studies. This review is limited to interventions with primary outcomes of reductions in injuries, falls and the prevalence of home hazards. It does not comment on the effectiveness of physical modification of the home environment with the intention of influencing other outcome measures, for example, morbidity, satisfaction, independence or quality of life.

\section{AUTHORS, CONCLUSIONS}

\section{Implications for practice}

The conclusion of this systematic review is that there is very little high-grade evidence that interventions to modify the home physical environment affect the likelihood of sustaining an injury in the home.

Injuries occur as a result of complex interactions between individuals and the environment and can always be considered multifactorial in nature. The results of this systematic review of modifying the physical environment in the home to reduce injuries (with the exception of the provision and promotion of smoke alarm ownership, which was excluded from the review) demonstrate a paucity of evidence on which to base current practice. Whilst it is logical to deduce that physical hazards and poor design and layout contribute to a sequence of events culminating in an injury, it is not possible to conclude that the amelioration of such hazards will definitely reduce the number of injuries. Nor is it possible to determine which aspects of multifactorial interventions are most cost effective. In the absence of good quality evidence, it is human nature for individuals to use interventions in the hope that they might be effective. This review has not shown that such interventions do not work. Limitations within the studies meant it was difficult to reach definitive conclusions in most cases.

\section{Implications for research}

RCTs provide the gold standard for the assessment of the effectiveness of interventions. This review shows the paucity of appropriately designed and sized studies to test the effectiveness of interventions to remove or reduce physical hazards in the home environment in reducing injury occurrence.

Studies were generally too small to have sufficient power to detect anything but a very large effect and rarely employed a factorial design that would allow an assessment of specific interventions as part of a multifactorial intervention. Most studies had very low uptake rates for interventions. The active involvement of participants in the design of studies might improve this. The challenge to the global injury research community is to collaborate to design and implement studies of a sufficient size, rigorous design and acceptability to participants to answer these important questions.

\section{ACKNOWLEDGEMENTS}

The authors would like to thank Emma Sydenham from the Cochrane Injuries Group for her guidance and support during the review process.

The authors would also like to thank everyone who has contributed towards earlier versions of the review including: Lesley Victoria Sander, Sinead Brophy, Nikki Weaver, Sian King, Antony Johansen, Alison Kemp, Joanne Patterson and Ben Rolfe, Frances Bunn, Katherine Ker, Stephen Palmer \& Sylvia Morgan. 


\section{R E F E R E N C E S}

\section{References to studies included in this review}

\section{Babul 2007 \{published data only\}}

Babul S, Olsen L, Janssen P, McIntee P, Raina P, Babul S, et al.A randomized trial to assess the effectiveness of an infant home safety programme. International Journal of Injury Control \& Safety Promotion 2007;14(2):109-17.

\section{Becker 2003 \{published data only\}} Becker C, Kron M, Lindemann U, Sturm E, Eichner B, Walter-Jung B. Effectiveness of a multifaceted intervention on falls in nursing home residents. Journal of the American Geriatrics Society 2003;51:306-13.

\section{Campbell 2005 \{published data only\}}

* Campbell AJ, Robertson MC, La Grow SJ, Kerse NM, Sanderson GF, Jacobs RJ, et al.Randomised controlled trial of prevention of falls in people aged greater than or equal to 75 with severe visual impairment: the VIP trial. BMJ 2005; 331(7520):817-20.

La Grow SJ, Robertson MC, Cambell AJ, Clarke GA, Kerse NM. Reducing hazard related falls in people 75 years and older with significant visual impairment: how did a successful program work?. Injury Prevention 2006;12 296-301.

Carter unpublished \{unpublished data only\} Carter S, Campbell E, Sanson-Fisher R, Corkrey R, Gillespie W. A trial of two strategies aimed at reducing falls through home hazard modification and medication review. Unpublished (permission to quote granted).

\section{Clamp 1998 \{published data only\}}

Clamp M, Kendrick D. A randomised controlled trial of general practitioner safety advice for families with children under 5 years. BMJ 1998;316:1576-9.

Close 1999 \{published data only\}

Close J, Ellis M, Hooper R, Glucksman E, Jackson S, Swift C. Prevention of falls in the elderly trial (PROFET):a randomised controlled trial. Lancet 1999;353:93-7.

\section{Cumming 1999 \{published data only\}} Cumming RG, Thomas M, Szonyi G, Salkeld G, O’Neill E, Westbury C, et al.Home visits by an occupational therapist for assessment and modification of environmental hazards:a randomized trial of falls prevention. Journal of the American Geriatrics Society 1999;47:1397-402.

Day 2002 \{published data only\} Day L, Fildes B, Gordon I, Fitzharris M, Flamer H, Lord S. Randomised factorial trial of falls prevention among older people living in their own homes. BMJ 2002;325:128-31.

Elley 2008 \{published data only\}

Elley CR, Robertson MC, Garrett S, Kerse NM, McKinlay E, Lawton B, et al.Effectiveness of a falls-and-fracture nurse coordinator to reduce falls: a randomized, controlled trial of at-risk older adults. Journal of the American Geriatrics Society 2008;56(8):1383-9.
Gielen 2002 \{published data only\}

* Gielen AC, McDonald EM, Wilson MEH, Hwang WT, Serwint J, Andrews JS, et al.Effects of improved access to safety counselling, products and home visits on parents' safety practices: Results of a randomized trial. Archives of Pediatrics \& Adolescent Medicine 2002;156:33-40. Gielen AC, Wilson ME, McDonald EM, Serwint JR, Andrews JS, Hwang WT, et al.Randomized trial of enhanced anticipatory guidance for injury prevention. Archives of Pediatrics and Adolescent Medicine 2001;155: 42-9.

\section{Gitlin 2006 \{published data only\}} Gitlin LN, Winter L, Dennis MP, Corcoran M, Schinfeld S, Hauck WW. A randomized trial of a multicomponent home intervention to reduce functional difficulties in older adults. Journal of the American Geriatrics Society 2006;54:809-16.

Hendrickson 2005 \{published data only\}

Hendrickson SG. Reaching an underserved population with a randomly assigned home safety intervention. Injury Prevention 2005;11(5):313-7.

\section{Hendriks 2008 \{published data only\}}

Hendriks MR, Bleijlevens MH, Van Haastregt JC, Crebolder HF, Diederiks JP, Evers SM, et al.Lack of effectiveness of a multidisciplinary fall-prevention program in elderly people at risk: a randomized, controlled trial. Journal of the American Geriatrics Society 2008;56(8): 1390-7.

Hogan 2001 \{published data only\}

Hogan DB, MacDonald FA, Betts J, Bricker S, Ebly EM, Delarue B, et al.A randomized controlled trial of a community-based consultation service to prevent falls. Canadian Medical Association Journal 2001;165(5):537-43.

Jenson 2002 \{published data only\}

* Jensen J, Lundin -Olsson L, Nyberg L, Gustafson Y. Fall and injury prevention in older people living in residential care facilities. Annals of Internal Medicine 2002;136: 733-41.

Jensen J, Nyberg L, Gustafson Y, Lundin-Olsson L. Fall and injury prevention in residential care - effects in residents with higher and lower levels of cognition. Journal of the American Geriatrics Society 2003;51:627-35.

Kendrick 1999 \{published data only\} Kendrick D, Marsh P, Fielding K, Miller P. Preventing injuries in children:cluster randomised controlled trial in primary care. BMJ 1999;318:980-3.

King 2005 \{published data only\}

King WJ, Klassen TP, LeBlanc J, Bernard-Bonnin AC, Robitaille Y, Pham B, et al.The effectiveness of a home visit to prevent childhood injury. Pediatrics 2001;108(2):382-8. * King WJ, LeBlanc JC, Barrowman NJ, Klassen TP, Bernard-Bonnin A-C, Robitaille Y, et al.Long term effects of a home visit to prevent childhood injury: three year follow up of a randomized trial. Injury Prevention 2005;11:106-9. 
Mahoney 2007 \{published data only\}

Mahoney JE, Shea TA, Przybelski R, Jaros L, Gangnon R, Cech S, et al.Kenosha County falls prevention study: a randomized, controlled trial of an intermediate-intensity, community-based multifactorial falls intervention. Journal of the American Geriatrics Society 2007;55(4):489-98.

Nikolaus 2003 \{published data only\}

Nikolaus T, Bach M. Preventing falls in communitydwelling frail older people using a home intervention team (HIT): results from the randomized Falls-HIT trial. Journal of the American Geriatrics Society 2003;51(3):300-5.

Pardessus 2002 \{published data only\}

Pardessus V, Parieux F, Di P, Gaudefroy C, Thevenon A, Dewailly P. Benifits of home visits for falls and autonomy in the elderly: a randomised study. American Journal of Physical Medicine and Rehabilitation 2002;81(4):247-52.

Posner 2004 \{published data only\}

Posner JC, Hawkins LA, Garcia-Espana F, Durbin DR. A randomized, clinical trial of a home safety intervention based in an emergency department setting. Pediatrics 2004; 113:1603-8.

Salminen 2009 \{published data only\}

Salminen M, Vahlberg T, Kivela SL. The long-term effect of a multifactorial fall prevention programme on the incidence of falls requiring medical treatment. Public Health 2009; 123(12):809-13.

* Salminen MJ, Vahlberg TJ, Salonoja MT, Aarnio PT, Kivela SL, Salminen Marika J, et al.Effect of a risk-based multifactorial fall prevention program on the incidence of falls. Journal of the American Geriatrics Society 2009;57(4): 612-9.

Sjosten NM, Salonoja M, Piirtola M, Vahlberg T, Isoaho $\mathrm{R}$, Hyttinen $\mathrm{H}$, et al.A multifactorial fall prevention programme in home-dwelling elderly people: A randomized-controlled trial. Public Health 2007;121: 308-18.

\section{Sangvai 2007 \{published data only\}}

Sangvai S, Cipriani L, Colborn DK, Wald ER, et al.Studying injury prevention: practices, problems, and pitfalls in implementation. Clinical Pediatrics 2007;46(3):228-35.

Shaw 2003 \{published data only\}

Shaw FE, Bond J, Richardson DA, Dawson P, Steen IN, McKeith IG. Multifactorial intervention after a fall in older people with cognitive impairment and dementia presenting to the accident and emergency department: randomised controlled trial. BMJ 2003;326:73-9.

Stevens 2001 \{published data only\} Stevens M, D’Arcy C, Holman J, Bennett N, De Klerk $\mathrm{N}$. Preventing falls in older people:outcome evaluation of a randomized controlled trial. Journal of the American Geriatrics Society 2001;49:1448-55.

Tinetti 1994 \{published data only\}

Tinetti ME, Baker DI, McAvay G, Blaus EB, Garrett P, Gottschalk M, et al.A multifactorial intervention to reduce the risk of falling among elderly people living in the community. New England Journal of Medicine 1994;331

(13):821-7.

Van Haastregt 2000b \{published data only\}

Van Haastregt JCM, Diederiks JPM, Van Rossum E, De Witte LP, Woorhoeve PM, Crebolder HF. Effects of a programme of multifactorial home visits on falls and mobility impairments in elderly people at risk: randomised controlled trial. BMJ 2000;321:994-8.

Vetter 1992 \{published data only\}

Vetter N, Lewis P, Ford D. Can health visitors prevent fractures in elderly people?. BMJ 1992;304:888-90.

Watson 2005 \{published data only\}

Watson M, Kendrick D, Coupland C, Woods A, Futers D, Robinson J. Providing child safety equipment to prevent injuries: randomised controlled trial. BMJ 2005;330:178.

\section{References to studies excluded from this review}

Assantachai 2002 \{published data only\}

Assantachi P, Chatthanaearee W, Thamlikitkul V, Praditsuwan R, Pisalsarakij D. Strategy to prevent falls in the Thai elderly: a controlled study integrated health research program for the Thai elderly. Journal of the Medical Association of Thailand 2002;85:215-22.

Barnes 2004 \{published data only\}

Barnes BR, Mathee A, Krieger L, Shafritz L, Favin M, Sherburne L, et al. Testing selected behaviors to reduce indoor air pollution exposure in young children. Health Education Research 2004;19(5):543-50.

Binns 2004 \{published data only\} Binns HJ, Gray KA, Chen T, Finster ME, Peneff N, Schaefer $\mathrm{P}$, et al.Evaluation of landscape coverings to reduce soil lead hazards in urban residential yards: The Safer Yards Project. Environmental Research 2004;96(2):127-38.

Boreland 2006 \{published data only\}

Boreland F, Lyle DM, Boreland F, Lyle DM. Lead dust in Broken Hill homes: effect of remediation on indoor lead levels. Environmental Research 2006;100(2):276-83.

Bouwen 2008 \{published data only\}

Bouwen A, De Lepeleire J, Buntinx F, Bouwen A De Lepeleire J, Buntinx F. Rate of accidental falls in institutionalised older people with and without cognitive impairment halved as a result of a staff-oriented intervention. Age \& Ageing 2008;37(3):306-10.

Caplan 2004 \{published data only\}

Caplan GA, Williams AJ, Daly B, Abraham K. A randomized, controlled trial of comprehensive geriatric assessment and multidisciplinary intervention after discharge of elderly from the emergency department - the DEED II study. Journal of the American Geriatrics Society 2004;52(9):1417-23.

Carman 2006 \{published data only\}

Carman J, Friedman E, Lamb D, Lennon K. Evaluating the impact of a child injury prevention project. Community Practitioner 2006;79(6):188-92. 
Casteel 2004 \{published data only\}

Casteel C, Peek-Asa C, Lacsamana C, Vazquez L, Kraus JF. Evaluation of a falls prevention program for independent elderly. American Journal of Health Behavior 2004;28: S51-60.

Ciaschini 2009 \{published data only\} Ciaschini PM, Straus SE, Dolovich LR, Goeree RA, Leung $\mathrm{KM}$, Woods CR, et al.Community-based intervention to optimise falls risk management: a randomised controlled trial. Age \& Ageing 2009;38(6):724-30.

Clemson 1996 \{published data only\} Clemson L. Case-control study of hazards in the home. Age and Aging 1996;25:97-101.

Colver 1982 \{published data only\}

Colver AF, Hutchinson PJ, Judson EC. Promoting children's home safety. BMJ 1982;285:1177-80.

\section{Conn 2005 \{published data only\}}

Conn L. Mind your Step! A falls prevention programme designed to reduce falls in those over 75 years. Quality in Ageing 2005;8(1):10-22.

Dershewitz 1979 \{published data only\}

Dershewtiz RA. Will mothers use free household safety devices?. American Journal of Diseases in Childhood 1979; 133:61-4.

Diener 2005 \{published data only\}

Diener DD, Mitchel JM. Impact of a multifactorial fall prevention program upon falls of older frail adults attending an adult health day care center. Topics in Geriatric Rehabilitation 2005;21(3):247-57.

Dixon 2009 \{published data only\}

Dixon SL, Fowler C, Harris J, Moffat S, Martinez Y,

Walton $\mathrm{H}$, et al.An examination of interventions to reduce respiratory health and injury hazards in homes of lowincome families. Environmental Research 2009;109(1): 123-30.

Duff 2002 \{published data only\}

Duff S, Ryan M, Mullan C, O'Keefe B, Nicholson AJ. The use of local accident and emergency injury surveillance to monitor the impact of a lay safety community programme. Irish Medical Journal 2002;95(5):143-5.

Durongritichai 2003 \{published data only\}

Durogritichai V, Tongvichean S, Silapasuwan P,

Plitponkarnpim A, Nontapatamadul K. Caregiver self-help group development for preschooler home injury prevention: community-action research perspective. Thai Journal of Nursing Research 2003;7(1):23-36.

Fergusson 2005 \{published data only\}

Fergusson DM, Grant H, Horwood LJ, Ridder EM.

Randomized trial of the Early Start program of home visitation. Pediatrics 2005;116(6):e803-9.

Filiatrault 2007 \{published data only\}

Filiatrault J, Parisien M, Laforest S, Genest C, Gauvin

L, Fournier M, et al.Implementing a community-based falls-prevention program: from drawing board to reality. Canadian Journal on Aging 2007;26(3):213-25.
Gerson 2005 \{published data only\}

Gerson LW, Camargo CA Jr, Wilber ST. Home modification to prevent falls by older ED patients. American Journal of Emergency Medicine 2005;23(3):295-8.

Gillespie-Bennett 2008 \{published data only\} Gillespie-Bennett J, Pierse N, Wickens K, Crane J, Nicholls $S$, Shields D, et al.Sources of nitrogen dioxide (NO2) in New Zealand homes: findings from a community randomized controlled trial of heater substitutions. Indoor Air 2008; 18(6):521-8.

Ginnelly 2005 \{published data only\} Ginnelly L, Sculpher M, Bojke C, Roberts I, Wade A, Diguiseppi $\mathrm{C}$, et al.Determining the cost effectiveness of a smoke alarm give-away program using data from a randomized controlled trial. European Journal of Public Health 2005;15(5):448-53.

Haynes 2003 \{published data only\}

Haynes R, Reading R, Gale S. Household and neighbourhood risks for injury to 5-14 year old children. Social Science \& Medicine 2003;57(4):625-36.

Hermann 1999 \{published data only\}

Hermann R, Meier-Baumgartner HP. Hip-fracture in the elderly caused by a fall - etiology and rehabilitation [Die sturzbedingte, proximale Femurfraktur alterer Menschen Atiologie und Rehabilitation]. Zeitschrift fur Gerontologie und Geriatrie 1999;32:52-7.

Hornbrook 1994 \{published data only\} Hornbrook MC, Stevens VJ, Wingfield DJ, Hollis JF, Greenlick MR, Ory MG. Preventing falls among community-dwelling older persons: results from a randomized trial. Gerontologist 1994;34(1):16-23.

Huang 2003 \{published data only\} Huang H, Gau M, Lin W. Assessing risk of falling in older adults. Public Health Nursing 2003;20(5):399-411.

Huang 2004 \{published data only\}

Huang T, Acton G. Effectiveness of home visit falls prevention strategy for Taiwanese community-dwelling elders: a randomized trial. Public Health Nursing 2004;21 (3):247-56.

Iwarsson 2009 \{published data only\} Iwarsson S, Horstmann V, Carlsson G, Oswald F, Wahl H. Person-environment fit predicts falls in older adults better than the consideration of environmental hazards only. Clinical Rehabilitation 2009;23(6):558-67.

Johnston 2000 \{published data only\}

Johnston BD, Britt J, D’Ambrosio L, Mueller BA, Rivara FP. A preschool program for safety ad injury prevention delivered by home visitors. Injury Prevention 2000;6: 305-09.

Katcher 1989 \{published data only\} Katcher ML, Landry GL, Shapiro MM. Liquid-crystal thermometer use in pediatric office counseling about tap water burn prevention. Pediatrics 1989;83(5):766-71. 
Kelly 1987 \{published data only\}

Kelly B, Sein C, McCarthy PL. Safety education in a pediatric primary care setting. Pediatrics $1987 ; 79$ (5) 818-24.

Kendrick 2008 \{published data only\} Kendrick D, Stewart J, Coupland C, Hayes M, Hopkins $\mathrm{N}$, McCabe D, et al.Randomised controlled trial of thermostatic mixer valves in reducing bath hot tap water temperature in families with young children in social housing: a protocol. Trials [Electronic Resource] 2008;9:14.

\section{Kerse 2004 \{published data only\}}

Kerse N, Butler M, Robinson E, Todd M, Kerse Ngaire, Butler Meg, et al.Fall prevention in residential care: a cluster, randomized, controlled trial. Journal of the American Geriatrics Society 2004;52(4):524-31.

Laffoy 1997 \{published data only\}

Laffoy M. Childhood accidents in the home. Irish Medical Journal 1997;90(1):26-7.

\section{Lamb 2008 \{published data only\}}

Lamb SE, Fisher JD, Gates S, Potter R, Cooke MW, Carter $\mathrm{YH}$. A national survey of services for the prevention and management of falls in the UK. BMC Health Services Research 2008;8:233.

Lannin 2007 \{published data only\} Lannin NA, Clemson L, McCluskey A, Lin CW, Cameron ID, Barras $S$, et al.Feasibility and results of a randomised pilot-study of pre-discharge occupational therapy home visits. BMC Health Services Research 2007;7:42.

Lightbody 2002 \{published data only\} Lightbody E, Watkins C, Leathley M, Sharma A, Lye M. Evaluation of a nurse-led falls prevention programme versus usual care: a randomized controlled trial. Age and Aging 2002;31(3):203-10.

\section{Lin 2007 \{published data only\}}

Lin MR, Wolf SL, Hwang HF, Gong SY, Chen CY. A randomized, controlled trial of fall prevention programs and quality of life in older fallers. Journal of the American Geriatrics Society 2007;55(4):499-506

\section{Llewellyn 2003 \{published data only\}}

Llewellyn G, McConnell D, Honey A, Mayes R, Russo D. Promoting health and home safety for children of parents with intellectual disability: a randomized control trial. Research in Developmental Disabilities 2003;24:405-31.

McLean 1996 \{published data only\} McLean D, Lord S. Falling in older people at home: transfer limitations and environmental risk factors. Australian Occupational Therapy Journal 1996;43:13-8.

McMurdo 2000 \{published data only\} McMurdo ET, Millar AM, Daly F. A randomized controlled trial of fall prevention strategies in old peoples' homes. Gerontology 2000;46:83-7.

Minkovitz 2010 \{published data only\} Minkovitz MD, Hughart N, Strobino D, Scharfstein D, Grason $\mathrm{H}$, Hou W, et al.A practice-based intervention to enhance quality of care in the first 3 years of life. JAMA 2003;290(23):3081-91.

Morgan 2005 \{published data only\}

Morgan RO, Devito CA, Stevens JA, Branche CM, Virnig $\mathrm{BA}$, Wingo PA, et al.A self-assessment tool was reliable in identifying hazards in the homes of elders. Journal of Clinical Epidemiology 2005;58(12):1252-9.

Morgenstern 2000 \{published data only\} Morgenstern H, Bingham T, Reza A. Effects of pool-fencing ordinances and other factors. American Journal of Public Health 2000;90(4):595-601.

Nelson 2005 \{published data only\}

Nelson CS, Higman SM, Sia C, McFarlane E, Fuddy L, Duggan AK, et al.Medical homes for at-risk children: parental reports of clinician-parent relationships, anticipatory guidance, and behavior changes. Pediatrics 2005;115(1):48-56.

Neno 2008 \{published data only\}

Neno R. The rise of falls research. Nursing Older People 2008;20(6):8-9.

Neyens 2009 \{published data only\}

Neyens JC, Dijcks BP, Twisk J, Schols JM, Van Haastregt JC, Van den Heuvel WJ, et al.A multifactorial intervention for the prevention of falls in psychogeriatric nursing home patients, a randomised controlled trial (RCT). Age \& Ageing 2009;38(2):194-9.

Northridge 1995 \{published data only\}

Northridge ME, Nevitt MC, Kelsey JL, Link B. Home hazards and falls in the elderly: the role of health and functional status. American Journal of Public Health 1995; 85(4):509-15.

Odendaal 2009 \{published data only\} Odendaal W, Van Niekerk A, Jordaan E, Seedat M. The impact of a home visitation programme on household hazards associated with unintentional childhood injuries: a randomised controlled trial. Accident Analysis \& Prevention 2009;41(1):183-90.

\section{Ozanne-Smith 2002 \{published data only\}}

Ozanne-Smith J, Day L, Stathakis V, Sherrard J. Controlled evaluation of a community based injury prevention program in Australia. Injury Prevention 2002;8(1):18-22.

Paul 1994 \{published data only\} Paul CL, Sanson-Fisher RW, Redman S. Preventing accidental injury to young children in the home using volunteers. Health Promotion International 1994;9(4): 241-9.

Peel 2000 \{published data only\}

Peel N, Steinberg M, Williams G. Home safety assessment in the prevention of falls among older people. Australian and New Zealand Journal of Public Health 2000;24:536-9.

Peeters 2007 \{published data only\}

Peeters GM, De Vries OJ, Elders PJ, Pluijm SM, Bouter LM, Lips P, et al.Prevention of fall incidents in patients with a high risk of falling: design of a randomised controlled trial with an economic evaluation of the effect of 
multidisciplinary transmural care. BMC Geriatrics 2007;7: 15.

\section{Petridou 1996 \{published data only\}}

Petridou E, Polychronopoulou A, Dounis E, Tsampira P, Revinthi K, Trichopoulos D. Risk factors for injuries among the elderly in Greece. Accident Analysis and Prevention 1996; 28(3):333-8.

\section{Petridou 1997 \{published data only\}}

Petridou E, Tolma E, Dessypris N, Trichopoulos D. A controlled evaluation of a community injury prevention project in two Greek islands. International Journal of Epidemiology 1997;26(1):173-9.

Plautz 1996 \{published data only\} Plautz B, Beck DE, Selmar C, Radetsky M. Modifying the environment: a community-based injury-reduction program for elderly residents. American Journal of Preventive Medicine 1996;12(suppl.1):33-8.

\section{Poulstrop 2000 \{published data only\}} Poulstrop A, Jeune B. Prevention of fall injuries requiring hospital treatment among community-dwelling elderly. European Journal of Public Health 2000;10:45-50.

\section{Pressley 2009 \{published data only\}} Pressley JC, Kiragu A, Lapidus G, Pomerantz WJ, Ford H, Barlow B, et al.Race and ethnic differences in a multicenter study of home safety with vouchers redeemable for free safety devices. Journal of Trauma-Injury Infection \& Critical Care 2009;67(1 Suppl):S3-11.

\section{Ramsey 2003 \{published data only\}} Ramsay LJ, Moreton G, Gorman DR, Blake E, Goh D, Elton RA, et al.Unintentional home injury in preschoolaged children: Looking for the key - an exploration of the inter-relationship and relative importance of potential risk factors. Public Health 2003;117(6):404-11.

Rizawati 2008 \{published data only\}

Rizawati M Mas Ayu. Home environment and fall at home among the elderly in Masjid Tanah Province. Journal of the University of Malaya Medical Centre 2008;11(2):72-82.

Roberts 2004 \{published data only\} Roberts H, Curtis K, Liabo K, Rowland D, Diguiseppi C, Roberts I, et al.Putting public health evidence into practice: increasing the prevalence of working smoke alarms in disadvantaged inner city housing. Journal of Epidemiology \& Community Health 2004;58(4):280-5.

Robertson 2005 \{published data only\} Robertson AS, Rivara FP, Ebel BE, Lymp JF, Christakis DA, Robertson AS, et al.Validation of parent self-reported home safety practices. Injury Prevention 2005;11(4):209-12.

Robson 2003 \{published data only\}

Robson E, Edwards J, Gallagher E, Baker D. Steady as you go (SAYGO): A falls-prevention program for seniors living in the community. Canadian Journal on Aging 2003;22(2): 207-16.

\section{Runyan 1992 \{published data only\}}

Runyan CW, Bangdiwala SI, Linzer MA, Sacks JJ, Butts J. Risk factors for fatal residential fires. New England Journal of Medicine 1992;327(12):859-63.

Sattin 1998 \{published data only\} Sattin RW, Rodriguez JG, DeVito CA, Wingo PA. Home environmental hazards and the risk of fall injury events among community-dwelling older persons. Journal of the American Geriatrics Society 1998;46:669-76.

Schwarz 1993 \{published data only\} Schwarz DF, Grisso JA, Miles C, Holmes JH, Sutton RL. An injury prevention program in an urban African-American community. American Journal of Public Health 1993;83: 675-80.

Schwebel 2009 \{published data only\} Schwebel DC, Swart D, Hui SK, Simpson J, Hobe P. Paraffin-related injury in low-income South African communities: knowledge, practice and perceived risk. Bulletin of the World Health Organization 2009;87(9): 700-6.

Spiegel 1977 \{published data only\} Spiegel CN, Lindaman FC. Children can't fly: a program to prevent childhood morbidity and mortality from window falls. American Journal of Public Health 1977;67:1143-7.

Steinberg 2000 \{published data only\}

Steinberg M, Cartwright C, Peel N, Williams G. A sustainable programme to prevent falls and near falls in community dwelling older people: results of a randomised trial. Journal of Epidemiology and Community Health 2000; 54:227-32.

Stone 2007 \{published data only\}

Stone KE, Eastman EM, Gielen AC, Squires B, Hicks G, Kaplin D, et al.Home safety in inner cities: prevalence and feasibility of home safety-product use in inner-city housing. Pediatrics 2007;120(2):E346-53.

Studenski 1994 \{published data only\} Studenski S, Duncan PW, Chandler J, Samsa G, Prescott B, Hogue C, et al.Predicting falls: the role of mobility and nonphysical factors. Journal of the American Geriatrics Society 1994;42:297-302.

\section{Swart 2008 \{published data only\}}

Swart L, Van Niekerk A, Seedat M, Jordaan E. Paraprofessional home visitation program to prevent childhood unintentional injuries in low-income communities: a cluster randomized controlled trial. Injury Prevention 2008;14(3):164-9.

\section{Sznajder 2003 \{published data only\}}

Sznajder M, Leduc S, Janvrin MP, Bonnin MH, Aegerter P, Baudier F, et al.Home delivery of an injury prevention kit for children in four French cities: a controlled randomized trial. Injury Prevention 2003;9(3):261-5.

Tanner 2003 \{published data only\}

Tanner E. Assessing home safety in homebound older adults. Geriatric Nursing 2003;24(4):250-4. 
Thomas 1984 \{published data only\}

Thomas KA, Hassanein RS, Christophersen ER. Evaluation of group well-child care for improving burn prevention practices in the home. Pediatrics 1984;74(5):879-82.

Thompson 1996 \{published data only\}

Thompson PG. Preventing falls in the elderly at home: a community-based program. Medical Journal of Australia 1996;164:530-2.

Tideiksaar 1990 \{published data only\}

Tideiksaar R. The biomedical and environmental characteristics of slips, stumbles and falls in the elderly. In: Gray, BE editor(s). Slips, Stumbles and Falls: pedestrian footwear and surfaces. Philadelphia: American Society for Testing and Materials, 1990:17-27.

Van Rijn 1991 \{published data only\}

Van Rijn OJ, Bouter LM, Kester AD, Knipschild PG, Meertens RM. Aetiology of burn injuries among children aged 0-4 years: results of a case-control study. Burns 1991; 17(3):213-9.

\section{Vind 2009 \{published data only\}}

Vind ABA. An outpatient multifactorial falls prevention intervention does not reduce falls in high-risk elderly Danes. Journal of the American Geriatrics Society 2009;57(6):June.

\section{Wagner 1994 \{published data only\}}

Wagner EH, LaCroix AZ, Grothaus L, Leveille SG, Hecht JA, Artz K, et al.Preventing disability and falls in older adults:a population-based randomized trial. American Journal of Public Health 1994;84(11):1800-6.

Waller 1993 \{published data only\}

Waller AE, Clarke JA, Langley JD. An evaluation of a program to reduce home hot tap water temperatures. Australian Journal of Public Health 1993;17(2):116-23.

Weatherall 2004 \{published data only\}

Weatherall M. A targeted falls prevention programme plus usual care significantly reduces falls in elderly people during hospital stays. Evidence-Based Healthcare and Public Health 2004;8(5):Oct.

Wyman 2007 \{published data only\}

Wyman JF, Croghan CF, Nachreiner NM, Gross CR, Stock HH, Talley K, et al.Effectiveness of education and individualized counseling in reducing environmental hazards in the homes of community-dwelling older women. Journal of the American Geriatrics Society 2007;55(10): 1548-56.

Xia 2009 \{published data only\}

Xia QH, Jiang Y, Niu CJ, Tang CX, Xia ZL, Xia QH, et al.Effectiveness of a community-based multifaceted fallprevention intervention in active and independent older Chinese adults. Injury Prevention 2009;15(4):248-51.

Yang 2008 \{published data only\}

Yang J, Peek-Asa C, Jones MP, Nordstrom DL, Taylor C, Young TL, et al.Smoke alarms by type and battery life in rural households: a randomized controlled trial. American Journal of Preventive Medicine 2008;35(1):20-4.
Yates 2001 \{published data only\}

Yates SM, Dunnagan TA. Evaluating the effectiveness of a home-based fall risk reduction program for rural community-dwelling older adults. Journal of Gerontology 2001;56A(4):M226-30.

\section{Ytterstad 1996 \{published data only\}}

Ytterstad B. The Harstad injury prevention study: community based prevention of fall-fractures in the elderly evaluated by means of a hospital based injury recording system in Norway. Journal of Epidemiology and Community Health 1996;50:551-8.

\section{Additional references}

\section{Campbell 1997}

Campbell AJ, Robertson MC, Gardner MM, Norton RN, Tilyard MW, Buchner DM. Randomised controlled trial of a general practice programme of home based exercise to prevent falls in elderly women. BMJ 1997;315(7115): 1065-9.

\section{Campbell 2007}

Campbell AJ, Robertson MC. Rethinking individual and community fall prevention strategies: a meta-regression comparing single and multifactorial interventions. Age Ageing 2007;36(6):656-62.

\section{Chang 2004}

Chang JT, Morton SC, Rubenstein LZ, Mojica WA, Maglione M, Suttorp MJ, et al.Interventions for the prevention of falls in older adults: systematic review and meta-analysis of randomised clinical trials. BMJ 2004;328 (7441):680-7.

\section{Coleman 1996}

Munro J, Coleman P, Nicholl J, Harper R. The effectiveness of interventions to prevent accidental injury to young persons aged 15-24 years: a review of the evidence. Sheffield: University of Sheffield Medical Care Research Unit, 1996.

DH 2009

Department of Health. Effective interventions in health and social care. London: DH, 2009.

DiGuiseppi 2001

DiGuiseppi C, Higgins JPT. Interventions for promoting smoke alarm ownership and function. Cochrane Database of Systematic Reviews 2001, Issue 2. [DOI: 10.1002/ 14651858.CD002246]

\section{DoH 2001}

Department of Health. National Service Framework for older people. London: Department of Health, 2001.

\section{DTI 1997}

Department of Trade and Industry. Home accident surveillance system. Accident data and safety research - home, garden and leisure. Vol. Annual Report 21, London: DTI, 1997.

Elkan 2000

Elkan R, Kendrick D, Hewitt M, National Coordinating Centre for HTA. The effectiveness of domiciliary health visiting: a systematic review of international studies and a 
selective review of the British literature. Vol. 4(13), Alton: Core Research, 2000.

\section{EU 2006}

Council of the European Union. Communication from the Commission to the European Parliament and the Council on Actions for a Safer Europe. Brussels: Council of the European Union, 2006.

\section{Gates 2007}

Gates S, Lamb SE, Fisher JD, Cooke MW, Carter YH. Multifactorial assessment and targeted intervention for preventing falls and injuries among older people in community and emergency care settings: systematic review and meta-analysis. BMJ 2007;336:130-3. [: bmj.39412.525243.BE]

Health Development Agency 2003

Health Development Agency. Prevention and reduction of accidental injury in children and older people. London, 2003.

\section{Hewitt 2008}

Hewitt CE, Mitchell N, Torgerson DJ. Listen to the data when results are not significant. BMJ 2008;336(7634): 23-5.

\section{Jensen 2003}

Jensen J, Nyberg L, Gustafson Y, Lundin-Olsson L. Fall and injury prevention in residential care - effects in residents with higher and lower levels of cognition. Journal of the American Geriatrics Society 2003;51:627-35.

\section{Johansen 1999}

Johansen A, Harding K, Evans R, Stone M. Trauma in elderly people:what proportion of fractures are a consequence of bone fragility?. Archives of Gerontology and Geriatrics 1999;29:215-21.

\section{King 2001}

King WJ, Klassen TP, LeBlanc J, Bernard-Bonnin AC, Robitaille Y, Pham B, et al.The effectiveness of a home visit to prevent childhood injury. Pediatrics 2001;108(2):382-8.

\section{Lilley 1995}

Lilley J, Arie T, Chivers C. Special reviews. Accidents involving older people: a review of the literature. Age and Ageing 1995;24:336-45.

\section{Lyons 1998}

Lyons R, Payne C, Sheppard S, Tomlinson J. Health Evidence Bulletins - Wales: Injury Prevention. Cardiff: Welsh Office, 1998.

\section{Lyons 2002}

Lyons RA, Jones S, Palmer SR, Kemp A, Sibert JR, Shepherd J, et al.Data from All Wales Injury Surveillance System. The development and use of a low-cost injury surveillance system: the All Wales Injury Surveillance System (AWISS). Injury Prevention 2002;8:83-6.

\section{Moher 1998}

Moher D, Pham B, Jones A, Cook DJ, Jadad AR, Moher $\mathrm{M}$, et al.Does quality of reports of randomised trials affect estimates of intervention efficacy reported in meta-analyses? . Lancet 1998;352(9128):609-13.

\section{NHS CRD 1996}

NHS Centre for Reviews \& Dissemination. Preventing falls and subsequent injury in older people. Effective Health Care 1996;2(4):1-16.

\section{NICE 2004}

National Institute for Health and Clinical Excellence. The assessment and prevention of falls in older people. London: NICE, 2004

\section{Parker 2005}

Parker MJ, Gillespie WJ, Gillespie LD. Hip protectors for preventing hip fractures in older people. Cochrane Database of Systematic Reviews 2005, Issue 3. [DOI: 10.1002/ 14651858.CD001255.pub3]

\section{Purdue 2003}

Perdue C. Falls in older people - taking a multi-disciplinary approach. Nursing Times 2003;99:28-30.

\section{Rehmani 2005}

Rehmani R. Reduction of home injury hazards by home visiting program: a randomized controlled trial. Annals of Emergency Medicine 2005;46(3):S86.

\section{RevMan 2008}

The Nordic Cochrane Centre, The Cochrane Collaboration. Review Manager (RevMan). Copenhagen: The Nordic Cochrane Centre, The Cochrane Collaboration, 2008; Vol. 5.0

\section{Robertson 2001}

Robertson MC, Devlin N, Gardner MM, Campbell AJ. Effectiveness and economic evaluation of a nurse delivered home exercise programme to prevent falls. 1: Randomised controlled trial. BMJ 2001;322(7288):697.

\section{Robertson 2001a}

Robertson MC, Gardner MM, Devlin N, McGee R, Campbell AJ. Effectiveness and economic evaluation of a nurse delivered home exercise programme to prevent falls. 2: Controlled trial in multiple centres. BMJ 2001;322 (7288):701.

\section{Rubenstein 2001}

Rubenstein LZ, Powers CM, MacLean CH. Quality indicators for the management and prevention of falls and mobility problems in vulnerable elders. Annals of Internal Medicine 2001;135(8 Part 2):686-93.

Scheidt 1995

Scheidt PC, Harel Y, Trumble AC, Jones DH, Overpeck MD, Bijur PE. The epidemiology of nonfatal injuries among US children and youth. American Journal of Public Health 1995;85(7):932-8.

\section{Schulz 1995}

Schulz KF, Chalmers I, Hayes RJ, Altman DG. Empirical evidence of bias: dimensions of methodological quality associated with estimates of treatment effects in controlled trials. JAMA 1995;273(5):408-12.

\section{Schulz 2000}

Schulz KF. Assessing allocation concealment and blinding in randomised controlled trials: why bother?. Evidence Based Medicine 2000;5(2):36-8 


\section{Thomson 200}

Thomson H, Petticrew M, Morrison D. Health effects of housing improvement:systematic review of intervention studies. BMJ 2001;323:187-90.

\section{Towner 2001}

Towner E, Dowswell T, Mackereth C, Jarvis S. What works in preventing unintentional injuries in children and young adolescents? An updated systematic review. London: Health Development Agency 2001.

\section{Van Haastregt 2000a}

Van Haastregt JCM, Diedericks JPM, Van Rossum E, De
Witte LP, Crebolder HF. Effects of preventive home visits to elderly people living in the community: a systematic review. BMJ 2000;320:754-8.

\section{WHO 2006}

World Health Organization. Child and adolescent injury prevention: A WHO plan of action 2006-2015. Geneva, Switzerland: WHO, 2006.

\section{Yardley 2005}

Yardley L, Todd C. Encouraging positive attitudes to falls prevention in later life. London: Help the Aged, 2005.

* Indicates the major publication for the study 
CHARACTERISTICS OF STUDIES

Characteristics of included studies [ordered by study ID]

Babul 2007

\begin{tabular}{ll}
\hline Methods & 3 armed parallel, non-blinded, RCT. \\
\hline Participants & $\begin{array}{l}\text { Parents of newborn infants, recruited from single public health unit, with } 82 \% \text { of the } \\
\text { population living in urban communities or suburban neighbourhoods and the balance in } \\
\text { the rural hillsides and farming areas } \\
\mathrm{n}=202(\mathrm{I} 1) . \\
\mathrm{n}=206(\mathrm{I} 2) ; \\
\mathrm{n}=192(\mathrm{C}) .\end{array}$ \\
\hline
\end{tabular}

Interventions

(I1) A home visit and home safety kit. A 41-item checklist was used to identify potential hazards in the home, and when identified parents were taught how to remove or modify these hazards. The nine home safety kit items included a smoke alarm, a coupon for $50 \%$ savings on a safety gate and cabinet locks

(I2) Home safety kit alone.

(C) The control group received standard services provided by the community health unit for families with newborn infants

Outcomes

Parent reported use of safety measures, attitudes toward safety and parent reported injury rates assessed by questionnaire. Outcomes evaluated using questionnaire completed at 2 month (baseline), 6-month and 12-month immunisation visits with community health nurse

Notes

Risk of bias

\begin{tabular}{lll}
\hline Bias & Authors' judgement & Support for judgement \\
\hline Allocation concealment (selection bias) & Low risk & \\
\hline
\end{tabular}

Becker 2003

\begin{tabular}{ll}
\hline Methods & Cluster RCT. \\
\hline Participants & $\begin{array}{l}\text { Long-stay residents } \geq 60 \text { from } 6 \text { community nursing homes. Mean age } 85 ; 79 \% \text { female } \\
\mathrm{n}=509(\mathrm{I}) . \\
\mathrm{n}=472(\mathrm{C}) .\end{array}$ \\
\hline
\end{tabular}

Interventions

Staff and resident education on fall prevention, advice on environmental adaptations, balance and resistance training, hip protectors. Participants could participate in any possible combination of intervention options for any time they wanted

Outcomes

Falls, injuries and fracture rates were documented for all facilities for 365 consecutive days from the same index date 
Becker 2003 (Continued)

Notes

Risk of bias

\begin{tabular}{lll}
\hline Bias & Authors' judgement & Support for judgement \\
\hline Allocation concealment (selection bias) & Low risk & Adequate. \\
\hline
\end{tabular}

Campbell 2005

\begin{tabular}{|c|c|c|}
\hline Methods & \multicolumn{2}{|l|}{ RCT. } \\
\hline Participants & \multicolumn{2}{|c|}{$\begin{array}{l}\text { Study set in Dunedin and Auckland, New Zealand. Men and women aged } \geq 75 \text { with visual } \\
\text { acuity of } 6 / 24 \text { or worse who were living in the community } \\
n=100 \text { (I1). } \\
n=97 \text { (I2). } \\
n=98 \text { (I3). } \\
n=96 \text { (C). }\end{array}$} \\
\hline Interventions & \multicolumn{2}{|c|}{$\begin{array}{l}\text { Recruitment took place over a } 12 \text {-month period beginning in October 2002, and partici- } \\
\text { pants were followed up for } 12 \text { months. The study included } 3 \text { interventions: } \\
\text { (I1) A home safety assessment and modification programme delivered by an occupational } \\
\text { therapist } \\
\text { (I2) An exercise programme prescribed at home by a physiotherapist plus vitamin D sup- } \\
\text { plementation } \\
\text { (I3) Both interventions. } \\
\text { (C) Social visits. } \\
\text { Environmental hazards were identified using the Westmead home safety assessment check- } \\
\text { list to identify hazards and to initiate discussion with the participant about any items, be- } \\
\text { haviour or lack of equipment that could lead to falls. The therapist and participant agreed } \\
\text { on which recommendations to implement, and the therapist facilitated the provision of } \\
\text { equipment and evaluated adherence to the home safety programme }\end{array}$} \\
\hline Outcomes & \multicolumn{2}{|c|}{$\begin{array}{l}\text { Compliance to home safety recommendations measured by a } 6 \text {-month follow-up telephone } \\
\text { call. Falls and fall related injuries were monitored for } 12 \text { months }\end{array}$} \\
\hline \multicolumn{3}{|l|}{ Notes } \\
\hline \multicolumn{3}{|l|}{ Risk of bias } \\
\hline Bias & Authors' judgement & Support for judgement \\
\hline Allocation concealment (selection bias) & Low risk & Adequate. \\
\hline
\end{tabular}




\section{Carter unpublished}

\begin{tabular}{ll}
\hline Methods & RCT. \\
\hline Participants & $\begin{array}{l}\text { Patients }>70 \text { years of age identified from patient lists of } 37 \text { family physicians. } \\
\mathrm{n}=163 \text { (I1). } \\
\mathrm{n}=133 \text { (I2). } \\
\mathrm{n}=161 \text { (C). }\end{array}$ \\
\hline Interventions & $\begin{array}{l}\text { Brief intervention - Home visit assessment of house/garden for hazards. Post-home visit - } \\
\text { summary of hazards found and given pamphlet on home safety and use of medications. } \\
\text { Intensive intervention - Home assessment as above. Post-assessment participant joint de- } \\
\text { velopment of action plan including actions to be taken to modify hazards found. Phone } \\
\text { prompts for action plan were provided after 3 and } 6 \text { months. 6-month follow-up advised to } \\
\text { see family physician for medication review. Home hazards not specifically reported. Control } \\
\text { group received no intervention }\end{array}$ \\
\hline Outcomes & $\begin{array}{l}\text { Falls and falls resulting in medical attention, hazard reduction. Fall related data was collected } \\
\text { via phone interviews at 3, } 6 \text { and } 12 \text { months, and hazard reduction data was collected during } \\
\text { the 12-month interview }\end{array}$ \\
\hline Allocation concealment (selection bias) & Low risk \\
\hline Nisk of bias & Authors' judgement Support for judgement \\
\hline Bias & Adequate. \\
\hline
\end{tabular}

\section{Clamp 1998}

\begin{tabular}{ll}
\hline Methods & RCT. \\
\hline Participants & $\begin{array}{l}\text { Families with children }<5 \text { years registered with a single-handed general practice. } \\
\mathrm{n}=83(\mathrm{I}) . \\
\mathrm{n}=82(\mathrm{C}) .\end{array}$ \\
\hline Interventions & $\begin{array}{l}\text { Intervention group families received GP safety advice and leaflets to promote the use of } \\
\text { smoke alarms, stair gates, fireguards, cupboard locks, covers for electric sockets and door } \\
\text { slam devices. Access to low-cost safety equipment was made available for families receiving } \\
\text { means tested state benefits. Control group families received usual care }\end{array}$ \\
\hline Outcomes & $\begin{array}{l}\text { Prevalence of safety devices and practices, collected } 6 \text { weeks after the intervention via a } \\
\text { questionnaire }\end{array}$ \\
\hline Notes & Authors' judgement Support for judgement \\
\hline Bias & of bias
\end{tabular}




\section{Clamp 1998 (Continued)}

Allocation concealment (selection bias) Low risk Adequate.

\section{Close 1999}

\begin{tabular}{ll}
\hline Methods & RCT. \\
\hline Participants & $\begin{array}{l}\text { All patients }>65 \text { years living in the local community who attended A \& E department with } \\
\text { a primary diagnosis of a fall between Dec } 1995 \text { and June } 1996 . \\
\mathrm{n}=184 \text { (I). } \\
\mathrm{n}=213 \text { (C). }\end{array}$ \\
\hline Interventions & $\begin{array}{l}\text { Intervention group participants received a single home visit by an occupational therapist } \\
\text { after medical assessment. Environmental hazards were identified using a checklist. Safety } \\
\text { advice and education was given on completion of the assessment, and modifications such } \\
\text { as removal of loose rugs were made with the patient's consent. Minor equipment was } \\
\text { supplied directly by the occupational therapist and additional support was referred to social } \\
\text { or hospital services. Control group patients received usual care }\end{array}$ \\
\hline Outcomes & $\begin{array}{l}\text { Primary diagnosis of a fall \& hospital admissions, collected via postal questionnaire every } \\
4 \text { months for } 1 \text { year after the fall }\end{array}$ \\
\hline Notes & \begin{tabular}{l} 
Low risk \\
\hline Bias
\end{tabular} \\
\hline Allocation concealment (selection bias) & Adequate. \\
\hline
\end{tabular}

\section{Cumming 1999}

\begin{tabular}{ll}
\hline Methods & RCT. \\
\hline Participants & $\begin{array}{l}\text { Inpatients, }>65 \text { years of age, in } 2 \text { hospitals. Also recruitment from outpatient clinics at } \\
\text { study hospitals and local day care centres for older people. } \\
\mathrm{n}=264(\mathrm{I}) . \\
\mathrm{n}=266(\mathrm{C}) .\end{array}$ \\
\hline Interventions & $\begin{array}{l}\text { Intervention group participants received home visit by an occupational therapist who con- } \\
\text { ducted a 1-hour home assessment using a standardised form to record hazards and facili- } \\
\text { tated necessary home modifications. Modifications included: removal of mats and electrical } \\
\text { cords, installation of non-slip mats, night-lights and stair rails and advice on footwear and } \\
\text { activities. Control group participants received usual care }\end{array}$ \\
\hline Outcomes & $\begin{array}{l}\text { Falls, and modifications to the home. Fall data was collected over a 12-month follow-up } \\
\text { period using monthly fall calendars and compliance with home modifications was recorded } \\
\text { during a 12-month follow-up home visit }\end{array}$ \\
\hline
\end{tabular}


Cumming 1999 (Continued)

\section{Notes}

Risk of bias

\begin{tabular}{lll}
\hline Bias & Authors' judgement & Support for judgement \\
\hline Allocation concealment (selection bias) & Low risk & Adequate. \\
\hline
\end{tabular}

Day 2002

\begin{tabular}{|c|c|c|}
\hline Methods & \multicolumn{2}{|l|}{ RCT. } \\
\hline Participants & \multicolumn{2}{|c|}{$\begin{array}{l}\text { Independent community-dwelling elderly }>70 \text { years of age registered on the Australian } \\
\text { electoral roll for the area. } \\
\mathrm{n}=395 \text { (I). } \\
\mathrm{n}=47 \text { (C). }\end{array}$} \\
\hline Interventions & \multicolumn{2}{|c|}{$\begin{array}{l}\text { Factorial intervention trial of group-based exercise including a balance component, home } \\
\text { hazard management and vision improvement delivered separately or combined. Control } \\
\text { participants received no intervention until after study end } \\
\text { Home hazards intervention consisted of a walk-through checklist for rooms used in a } \\
\text { normal week to review steps/stairs, floor surfaces, lighting, bathroom fittings and furniture } \\
\text { and the removal/modification of home hazards either by participants or via the City's } \\
\text { home maintenance staff. The control group received a home visit by a research nurse for } \\
\text { baseline questionnaire and risk factor measurements before randomisation took place (as } \\
\text { did intervention group), a falls calendar for monthly falls recording and other variables } \\
\text { (as did intervention group), phone call if their calendar was more than } 7-10 \text { days late in } \\
\text { being returned each month (as did intervention group), a phone call if fall reported and a } \\
\text { telephone interview regarding circumstances of the fall (as did intervention group), promise } \\
\text { of being given most effective intervention at study end. About } 50 \% \text { of control group were } \\
\text { re-visited at study end for risk factor measurements \& questionnaire (as did intervention } \\
\text { group). There was, however, no placebo intervention for the control group, so they did not } \\
\text { for example receive visits by a social worker etc }\end{array}$} \\
\hline Outcomes & \multicolumn{2}{|c|}{$\begin{array}{l}\text { Falls and hazard reduction. Fall data collected over } 18 \text {-month follow-up period using } \\
\text { monthly fall calendars and hazard data collected at } 18 \text { months also }\end{array}$} \\
\hline \multicolumn{3}{|l|}{ Notes } \\
\hline \multicolumn{3}{|l|}{ Risk of bias } \\
\hline Bias & Authors' judgement & Support for judgement \\
\hline Allocation concealment (selection bias) & Low risk & Adequate. \\
\hline
\end{tabular}


Elley 2008

\begin{tabular}{ll}
\hline Methods & RCT. \\
\hline Participants & 312 community-living people aged 75 and older who had fallen in the previous year \\
& $\mathrm{n}=155(\mathrm{I})$. \\
& $\mathrm{n}=157(\mathrm{C})$. \\
\hline
\end{tabular}

Interventions

Multicomponent intervention: Home-based nurse assessment of falls-and-fracture risk factors and home hazards, referral to appropriate community interventions, and strength and balance exercise programme

Outcomes

Fall data collected over a 12-month follow-up period using monthly fall calendars

Notes

\section{Risk of bias}

\begin{tabular}{lll}
\hline Bias & Authors' judgement & Support for judgement \\
\hline Allocation concealment (selection bias) & Low risk & \\
\hline
\end{tabular}

Gielen 2002

\begin{tabular}{|c|c|c|}
\hline Methods & \multicolumn{2}{|l|}{ RCT. } \\
\hline Participants & \multicolumn{2}{|c|}{$\begin{array}{l}\text { Paediatric residents in a large, urban teaching hospital in Maryland. Parents/guardians of } \\
\text { infants } 6 \text { months of age. } \\
\mathrm{n}=19 \text { (I1). } \\
\mathrm{n}=94 \text { (I2). } \\
\mathrm{n}=20(\mathrm{C} 1) \\
\mathrm{n}=93(\mathrm{C} 2) .\end{array}$} \\
\hline Interventions & \multicolumn{2}{|c|}{$\begin{array}{l}\text { Intervention group parents received safety counselling and referral to Children's Safety } \\
\text { Centre (providing safety products such as, safety gates, smoke alarms, and hot water ther- } \\
\text { mometers) from paediatric residents plus a home safety visit by community health worker } \\
\text { between patient's 6- and 9-month well-infant clinic visit. Paediatric residents received 2- } \\
\text { part training programme. (Physical hazards assessed during home visit unspecified.) Con- } \\
\text { trol group families received the same as above without the home visit }\end{array}$} \\
\hline Outcomes & \multicolumn{2}{|c|}{ Prevalence of safety practices collected at 12-18 months follow-up during home visit } \\
\hline \multicolumn{3}{|l|}{ Notes } \\
\hline \multicolumn{3}{|l|}{ Risk of bias } \\
\hline Bias & Authors' judgement & Support for judgement \\
\hline Allocation concealment (selection bias) & Low risk & Adequate. \\
\hline
\end{tabular}


Gitlin 2006

\begin{tabular}{|c|c|}
\hline Methods & Two-group randomised design with survivorship followed for 14 months \\
\hline Participants & $\begin{array}{l}\text { Urban community living adults aged } 70 \text { and older, who reported having difficulty with one } \\
\text { or more activities of daily living } \\
n=160 \text { (I). } \\
n=159 \text { (C). }\end{array}$ \\
\hline Interventions & $\begin{array}{l}\text { Multicomponent intervention. Occupational and physical therapy sessions involving home } \\
\text { modifications and training in their use, instruction in strategies of problem solving, en- } \\
\text { ergy conservation, safe performance, and fall recovery techniques; and balance and muscle } \\
\text { strength training } \\
\text { The six-month intervention consisted of five occupational therapy contacts and one physical } \\
\text { therapy visit. OT's identified and prioritised priority areas, and for each targeted area an } \\
\text { OT observed participants' performance for safety, efficiency and difficulty and presence } \\
\text { of environmental barriers. Before the sixth contact, home modifications were ordered and } \\
\text { installed (grab bars, rails, raised toilet seats) which were paid for through grant funds. } \\
\text { Over the following six months OTs conducted three telephone calls to reinforce use of } \\
\text { intervention derived strategies }\end{array}$ \\
\hline Outcomes & $\begin{array}{l}\text { Presence of } 106 \text { potential tripping and falling hazards (torn carpets, glare, lack of grab rails) } \\
\text { The home hazard index represented the total number of potentially unsafe conditions. } \\
\text { Data collected at } 6 \text { and } 12 \text { months follow-up }\end{array}$ \\
\hline \multicolumn{2}{|l|}{ Notes } \\
\hline \multicolumn{2}{|l|}{ Risk of bias } \\
\hline Bias & Support for judgement \\
\hline Allocation concealment (selection bias) & Low risk \\
\hline \multicolumn{2}{|l|}{ Hendrickson 2005} \\
\hline Methods & RCT: Pre-and post-test experimental design \\
\hline Participants & $\begin{array}{l}\text { Mothers of } 1-4 \text { year old children, English- or Spanish-speaking and agency qualified at or } \\
\text { below } 185 \% \text { of the US Federal poverty level, were recruited from a non-urban area in Texas } \\
\text { where migrant Hispanics represent the majority of residents } \\
n=41 \text { (I). } \\
n=41 \text { (C). }\end{array}$ \\
\hline Interventions & $\begin{array}{l}\text { The intervention was carried out } 1 \text { week after the baseline visit and included counselling, } \\
\text { assessment of maternal safety practices and provision of safety items. A researcher counselled } \\
\text { mothers regarding hazards reported during the first visit based on Health Belief Model } \\
\text { (HBM) constructs. One construct - behaviour accomplishment - involved mothers placing } \\
\text { free safety items and correcting hazards such as putting a working battery in a smoke detec- } \\
\text { tor. Mothers were also offered the option of having a photograph taken as they corrected a } \\
\text { hazard. Another construct - persuasion - was targeted towards individuals, but built around } \\
\text { a SafeKids brochure to stress the prevention of injuries }\end{array}$ \\
\hline
\end{tabular}


Hendrickson 2005 (Continued)

\begin{tabular}{|c|c|c|}
\hline Outcomes & \multicolumn{2}{|c|}{$\begin{array}{l}\text { Maternal childhood injury health beliefs }(\mathrm{MCIHB}) \text { and observed controllable safety hazards } \\
(\mathrm{CSH}) \text { scores collected } 6 \text { weeks after baseline visit via a home visit }\end{array}$} \\
\hline \multicolumn{3}{|l|}{ Notes } \\
\hline \multicolumn{3}{|l|}{ Risk of bias } \\
\hline Bias & Authors' judgement & Support for judgement \\
\hline Allocation concealment (selection bias) & Low risk & \\
\hline
\end{tabular}

Hendriks 2008

\begin{tabular}{ll}
\hline Methods & Two group RCT. \\
\hline Participants & $\begin{array}{l}333 \text { community dwelling Dutch people aged } 65 \text { and over who were seen in an emergency } \\
\text { department after a fall. Participants were also recruited from the GP Cooperative } \\
\mathrm{n}=166(\mathrm{I}) . \\
\mathrm{n}=167(\mathrm{C}) .\end{array}$ \\
\hline Interventions & $\begin{array}{l}\text { Multidisciplinary fall prevention programme. Intervention participants underwent a de- } \\
\text { tailed medical and occupational therapy assessment to evaluate and address risk factors } \\
\text { for recurrent falls, followed by recommendations and referral if indicated. Environmental } \\
\text { hazards were identified and recorded using a home safety checklist, and modifications were } \\
\text { referred to and delivered by social and community services }\end{array}$ \\
\hline Outcomes & $\begin{array}{l}\text { Falls and injurious falls collected over a 12-month follow-up period using monthly fall } \\
\text { calendars }\end{array}$ \\
\hline Notes & Authors' judgement Support for judgement \\
\hline Bisk of bias & Low risk \\
\hline Allocation concealment (selection bias)
\end{tabular}

Hogan 2001

\begin{tabular}{ll}
\hline Methods & RCT. \\
\hline Participants & $\begin{array}{l}\text { Ambulatory, community-dwelling residents, }>65 \text { years of age, of Calgary, Alberta. } \\
\mathrm{n}=79(\mathrm{I}) . \\
\mathrm{n}=84(\mathrm{C}) .\end{array}$
\end{tabular}




\section{Hogan 2001 (Continued)}

\begin{tabular}{|c|c|c|}
\hline Interventions & \multicolumn{2}{|c|}{$\begin{array}{l}\text { Intervention subjects received in-home assessments to identify both host and environmenta } \\
\text { risk factors in conjunction with the development of an individualised treatment plan } \\
\text { including an exercise programme for those deemed likely to benefit. } \\
\text { Environmental risk factors identified by example only. Examples include: no grab bars or } \\
\text { bath/shower and the removal of floor rugs. Control group participants received a hom } \\
\text { visit from a recreational therapist who performed a leisure assessment following which } \\
\text { letter was sent to each participant's GP }\end{array}$} \\
\hline Outcomes & \multicolumn{2}{|c|}{$\begin{array}{l}\text { Falls collected over a } 12 \text {-month follow-up period via monthly fall calendars, 3- and 6- } \\
\text { month home visits and telephone contact at } 12 \text { months }\end{array}$} \\
\hline \multicolumn{3}{|l|}{ Notes } \\
\hline \multicolumn{3}{|l|}{ Risk of bias } \\
\hline Bias & Authors' judgement & Support for judgement \\
\hline Allocation concealment (selection bias) & Low risk & Adequate. \\
\hline
\end{tabular}

Jenson 2002

\begin{tabular}{|c|c|c|}
\hline Methods & \multicolumn{2}{|l|}{ Cluster RCT. } \\
\hline Participants & \multicolumn{2}{|c|}{$\begin{array}{l}\text { Living in residential care facilities, }>65 \text { years. } \\
\mathrm{n}=194 \text { (I). } \\
\mathrm{n}=208 \text { (C). }\end{array}$} \\
\hline Interventions & \multicolumn{2}{|c|}{$\begin{array}{l}\text { Staff education, environmental adjustment, exercise, drug review, aids, hip protectors, post- } \\
\text { fall problem-solving conferences, guiding staff }\end{array}$} \\
\hline Outcomes & \multicolumn{2}{|c|}{ Falls and injuries collected over a 34-week follow-up period using a structured report form } \\
\hline \multicolumn{3}{|l|}{ Notes } \\
\hline \multicolumn{3}{|l|}{ Risk of bias } \\
\hline Bias & Authors' judgement & Support for judgement \\
\hline Allocation concealment (selection bias) & Low risk & Adequate. \\
\hline
\end{tabular}


Kendrick 1999

\begin{tabular}{ll}
\hline Methods & Cluster RCT. \\
\hline Participants & $\begin{array}{l}\text { All children aged 3-12 months registered with } 36 \text { participating general practices in Not- } \\
\text { tingham. All health visitors in Nottingham. } \\
\mathrm{n}=1100 \text { (I). } \\
\mathrm{n}=1019 \text { (C). }\end{array}$ \\
\hline Interventions & $\begin{array}{l}\text { Intervention group participants received: age-specific safety advice at child health surveil- } \\
\text { lance consultations at } 6-9,12-15 \text { and } 18-24 \text { months, provision of low-cost safety equip- } \\
\text { ment (stair gates, fireguards, cupboard locks and smoke alarms) to families on means tested } \\
\text { state benefits and home safety checks by a health visitor. Physical hazards checked during } \\
\text { home visit unspecified. Control group participants received usual care }\end{array}$ \\
\hline
\end{tabular}

Outcomes

Frequency and severity of medically attended injuries, ascertained from a search of the secondary and primary care records, at 25 months follow-up

Notes

Risk of bias

Bias

Authors' judgement Support for judgement

Allocation concealment (selection bias) Low risk $\quad$ Adequate.

King 2005

\begin{tabular}{ll}
\hline Methods & RCT. \\
\hline Participants & $\begin{array}{l}\text { Participants }<8 \text { years old presenting to the Emergency Departments at } 5 \text { hospitals in } 4 \\
\text { urban centres. } \\
\mathrm{n}=601(\mathrm{I}) . \\
\mathrm{n}=571(\mathrm{C}) .\end{array}$ \\
\hline Interventions & $\begin{array}{l}\text { Study research assistant conducted home visits to observe home safety hazards for both } \\
\text { control and intervention groups. Intervention group participants received an information } \\
\text { package on injury prevention, discount coupons for safety devices, specific instruction } \\
\text { regarding home safety measures and a letter from site project directors on need to maintain } \\
\text { preventive behaviours. Hazards measured were: access to small and dangerous objects, } \\
\text { absence of child resistant medicine containers, tap water greater than } 54^{\circ} \mathrm{C}, \text { functioning } \\
\text { smoke detectors, fire extinguishers, stair gates, infant walkers, ease of opening basement } \\
\text { door, absence of bicycle helmets and car restraints. Control group participants received } \\
\text { a general pamphlet on safety and notification if a non-functioning smoke detector was } \\
\text { found. All participants were contacted at } 4 \text { and } 8 \text { months after the initial visit to reinforce } \\
\text { the intervention }\end{array}$ \\
\hline Outcomes & \begin{tabular}{l} 
Injuries and hazard reduction recorded at 4,8 and 12 months \\
\hline
\end{tabular} \\
\hline
\end{tabular}

Notes 
King 2005 (Continued)

\begin{tabular}{lll} 
Risk of bias & & \\
\hline Bias & Authors' judgement & Support for judgement \\
\hline Allocation concealment (selection bias) & Low risk & Adequate. \\
\hline
\end{tabular}

Mahoney 2007

\begin{tabular}{ll}
\hline Methods & RCT. \\
\hline Participants & $\begin{array}{l}65 \text { years and older, with two falls in the previous year or one fall in the previous } 2 \text { years } \\
\text { with injury or balance problems } \\
\mathrm{n}=174(\mathrm{I}) . \\
\mathrm{n}=175(\mathrm{C}) .\end{array}$ \\
\hline Interventions & $\begin{array}{l}\text { The intervention used an algorithm based on the University of Wisconsin Falls Prevention } \\
\text { Clinic, designed to identify predisposing factors for falls; induce risk reduction changes } \\
\text { in medical conditions, medications, behaviour, physical status, and home environment } \\
\text { through recommendations to participants and their physicians, referrals to physical therapy } \\
\text { and other providers, } 11 \text { monthly telephone calls, and a balance exercise plan. Control } \\
\text { subjects received a home safety assessment }\end{array}$ \\
\hline Outcomes & $\begin{array}{l}\text { Falls were followed for } 12 \text { months using monthly fall calendars and telephone contact. All } \\
\text { hospitalisation and nursing home reports were verified using medical records }\end{array}$ \\
\hline Notes & Allocation concealment (selection bias) \\
\hline Risk of bias & Low risk \\
\hline Bias & Authors judgement Support for judgement \\
\hline
\end{tabular}

Nikolaus 2003

\begin{tabular}{ll}
\hline Methods & RCT with follow-up of subjects for 1 year. \\
\hline Participants & $\begin{array}{l}\text { Patients with functional decline, admitted from home to a geriatric clinic in southern } \\
\text { Germany } \\
\mathrm{n}=181 \text { assigned to geriatric assessment and home intervention team (I) } \\
\mathrm{n}=179 \text { assigned to geriatric assessment and usual care (C). }\end{array}$ \\
\hline Interventions & $\begin{array}{l}\text { Geriatric assessment and home intervention. Home intervention included an assessment } \\
\text { of the home for environmental hazards, advice about possible changes, offer of facilities to } \\
\text { modify the home environment, and training in the use of mobility and technical aids }\end{array}$
\end{tabular}


Nikolaus 2003 (Continued)

\begin{tabular}{|c|c|c|}
\hline Outcomes & \multicolumn{2}{|c|}{$\begin{array}{l}\text { Falls and compliance with home safety recommendations, measured at 12-month follow } \\
\text { up }\end{array}$} \\
\hline \multicolumn{3}{|l|}{ Notes } \\
\hline \multicolumn{3}{|l|}{ Risk of bias } \\
\hline Bias & Authors' judgement & Support for judgement \\
\hline Allocation concealment (selection bias) & Low risk & Adequate. \\
\hline
\end{tabular}

Pardessus 2002

\begin{tabular}{|c|c|c|}
\hline Methods & \multicolumn{2}{|l|}{ RCT. } \\
\hline Participants & \multicolumn{2}{|c|}{$\begin{array}{l}\text { Patients admitted to a geriatric hospital following a fall. Study set in Lille, France and mean } \\
\text { age } 83.5 \text { years } \\
\mathrm{n}=30 \text { (I). } \\
\mathrm{n}=30 \text { (C). }\end{array}$} \\
\hline Interventions & \multicolumn{2}{|c|}{$\begin{array}{l}\text { A home visit to assess environmental hazards and recommend modifications. Environmen- } \\
\text { tal hazards were identified using a check list and where possible modifications such as the } \\
\text { removal of loose carpets were made with the patient's consent. When a hazard could not } \\
\text { be removed the occupational therapist provided safety advice instead }\end{array}$} \\
\hline Outcomes & \multicolumn{2}{|c|}{$\begin{array}{l}\text { Falls collected by contacting each patient every month during 6-month follow-up and at } \\
12 \text { months }\end{array}$} \\
\hline \multicolumn{3}{|l|}{ Notes } \\
\hline \multicolumn{3}{|l|}{ Risk of bias } \\
\hline Bias & Authors' judgement & Support for judgement \\
\hline Allocation concealment (selection bias) & Low risk & Adequate. \\
\hline
\end{tabular}

Posner 2004

\begin{tabular}{ll}
\hline Methods & RCT. \\
\hline Participants & $\begin{array}{l}\text { Caregivers of }<5 \text { year olds who presented to casualty with acute unintentional injury } \\
\text { sustained at home } \\
\mathrm{n}=69(\mathrm{I}) . \\
\mathrm{n}=67(\mathrm{C}) .\end{array}$ \\
\hline Interventions & $\begin{array}{l}\text { Comprehensive home safety education and free home safety kit which included: cabinet } \\
\text { latches, drawer latches, electrical outlet covers, tub spout covers, non-slip bath decals, bath }\end{array}$
\end{tabular}


water thermometer, small parts tester (choking tube), poison control telephone number stickers, and literature related to fire and window safety

Outcomes

Degree of improvement in safety practices assessed by improvement in safety scores, collected by telephone contact at 6-8 weeks after the initial ED visit

Notes

\section{Risk of bias}

\begin{tabular}{lll}
\hline Bias & Authors' judgement & Support for judgement \\
\hline Allocation concealment (selection bias) & Low risk & Adequate. \\
\hline
\end{tabular}

\section{Salminen 2009}

\begin{tabular}{ll}
\hline Methods & RCT. \\
\hline Participants & $\begin{array}{l}591 \text { community dwelling } 65+\text { year olds, self selected between } 2003 \text { and 2005, via news } \\
\text { articles and mail-shots } \\
\mathrm{n}=293(\mathrm{I}) . \\
\mathrm{n}=298(\mathrm{C}) .\end{array}$ \\
\hline Interventions & $\begin{array}{l}\text { 12-month fall prevention programme based on individual risk analysis; geriatric assess- } \\
\text { ment, counselling and guidance in fall prevention, home hazard assessment, group physical } \\
\text { exercise, home exercise, lectures in groups and psychosocial groups }\end{array}$ \\
\hline Outcomes & Falls were followed for 12 months using monthly fall calendars \\
\hline Notes & Authors' judgement Support for judgement \\
\hline Risk of bias & Low risk \\
\hline Bias & Allocation concealment (selection bias) \\
\hline
\end{tabular}

Sangvai 2007

\begin{tabular}{ll}
\hline Methods & Prospective RCT. \\
\hline Participants & Trial conducted at 3 paediatric sites. Recruitment occurred from December 2002 to January \\
& 2004 and included parents of children aged 0 to 5 years who were with their child at a \\
health maintenance visit \\
$\mathrm{n}=160$ (I). \\
$\mathrm{n}=159$ (C).
\end{tabular}


Sangvai 2007 (Continued)

\begin{tabular}{|c|c|c|}
\hline Interventions & \multicolumn{2}{|c|}{$\begin{array}{l}\text { Multicomponent intervention including focused counselling from a physician and health } \\
\text { assistant, educational handouts, phone follow-up, and access to free safety devices and } \\
\text { automobile restraint evaluations. Intervention focused on } 5 \text { safety issues: use of automobile } \\
\text { restraints, use of smoke detectors, safe storage of hazardous materials (household cleaners } \\
\text { and medications), setting of appropriate tap water temperature }\left(<120^{\circ} \mathrm{F}\right) \text {, and safe storage } \\
\text { of guns. }\end{array}$} \\
\hline Outcomes & \multicolumn{2}{|c|}{$\begin{array}{l}\text { Prevalence of safety features collected by home visit and medically attended injuries collected } \\
\text { by chart review, both at } 6 \text {-month follow-up }\end{array}$} \\
\hline \multicolumn{3}{|l|}{ Notes } \\
\hline \multicolumn{3}{|l|}{ Risk of bias } \\
\hline Bias & Authors' judgement & Support for judgement \\
\hline Allocation concealment (selection bias) & Low risk & \\
\hline
\end{tabular}

Shaw 2003

\begin{tabular}{|c|c|c|}
\hline Methods & \multicolumn{2}{|c|}{ Prospective single centre RCT. } \\
\hline Participants & \multicolumn{2}{|c|}{$\begin{array}{l}\text { Older people aged } \geq 65 \text { years, cognitively impaired and dementia, presenting to casualty } \\
\text { following a fall. Study set in Newcatle upon Tyne } \\
n=130 \text { (I). } \\
n=144 \text { (C). }\end{array}$} \\
\hline Interventions & \multicolumn{2}{|c|}{$\begin{array}{l}\text { Multifactorial intervention involving a medical, cardiovascular, physiotherapy and occu- } \\
\text { pational therapy assessment and intervention. Occupational therapy assessment identified } \\
\text { environmental fall hazards using a standard checklist, and home hazard modification was } \\
\text { carried out using a standard protocol }\end{array}$} \\
\hline Outcomes & \multicolumn{2}{|c|}{$\begin{array}{l}\text { Falls, injury rates, objective effect on environmental risk factors. Fall and injury data } \\
\text { collected over a } 12 \text {-month follow-up period, using weekly diaries and A\&E department } \\
\text { records. Environmental risk factor data collected at } 3 \text { months' follow-up }\end{array}$} \\
\hline \multicolumn{3}{|l|}{ Notes } \\
\hline \multicolumn{3}{|l|}{ Risk of bias } \\
\hline Bias & Authors' judgement & Support for judgement \\
\hline Allocation concealment (selection bias) & Low risk & Adequate. \\
\hline
\end{tabular}


Stevens 2001

\begin{tabular}{ll}
\hline Methods & RCT. \\
\hline Participants & $\begin{array}{l}\text { Residents, aged } \geq 70 \text { years of age, living independently in the Perth metropolitan area and } \\
\text { listed on the State Electoral Roll and the White Pages telephone directory. } \\
\mathrm{n}=570(\mathrm{I}) . \\
\mathrm{n}=1167(\mathrm{C}) . \\
\text { Recruited and randomly allocated by household. }\end{array}$ \\
\hline Interventions & $\begin{array}{l}\text { All members of both the intervention and the control groups received a home visit from a } \\
\text { nurse. Intervention consisted of } 3 \text { strategies: a home hazard assessment, the installation of } \\
\text { free safety devices and an educational strategy to empower seniors to remove or modify home } \\
\text { hazards. Modifications included: installation of grab bars, removal of obstacles, removal/ } \\
\text { stabilisation of rugs and mats, repair of damaged flooring, improving the height of chairs } \\
\text { and improving poor lighting. Control subjects received no safety devices or information } \\
\text { on home hazard reduction }\end{array}$ \\
\hline
\end{tabular}

Outcomes

Falls, injurious falls, hazard reduction. Fall and injury data collected over a 12-month followup period using daily calendars and hazard reduction data was collected at 11 months' follow-up by postal questionnaire ( 51 homes received a second home hazard assessment to evaluate change in hazard prevalence)

Notes

Risk of bias

\begin{tabular}{lll}
\hline Bias & Authors' judgement & Support for judgement \\
\hline Allocation concealment (selection bias) & Low risk & Adequate. \\
\hline
\end{tabular}

\section{Tinetti 1994}

\begin{tabular}{ll}
\hline Methods & RCT. \\
\hline Participants & $\begin{array}{l}\geq 70 \text { years of age, members of a Health Maintenance Organisation (HMO) with one of } \\
\text { the following risk factors for falling: postural hypotension; use of sedatives; use at least } \\
\text { four prescription medications; and impairment in arm or leg strength or range of motion, } \\
\text { balance, ability to move safely from bed to chair or to the bathtub or toilet, or gait. } \\
\mathrm{n}=153(\mathrm{I}) .\end{array}$ \\
$\mathrm{n}=148(\mathrm{C})$. \\
\hline Interventions & $\begin{array}{l}\text { Multifactorial intervention. Intervention group received home assessment visit by a nurse } \\
\text { followed 1-week later by physical therapist. Nurse assessment included: postural hypoten- } \\
\text { sion, medication review and use, transfer and gait training skills, balance exercises and } \\
\text { exercises with resistive tools. Appropriate changes to environmental hazards for falls or } \\
\text { tripping were made such as removal of hazards, safer furniture (correct height, more stable) } \\
\text { installation of structures such as grab bars or handrails on stairs determined by room- } \\
\text { by-room assessment. Control group received home visits from social-work students where } \\
\text { structured interviews were conducted }\end{array}$ \\
\hline
\end{tabular}


Tinetti 1994 (Continued)

Outcomes Falls, collected over a 12-month follow-up period.

\begin{tabular}{lll}
\hline Notes & \\
\hline Risk of bias & Authors' judgement & Support for judgement \\
\hline Bias & Adequate. \\
\hline Allocation concealment (selection bias) & Low risk & \\
\hline
\end{tabular}

Van Haastregt 2000b

\begin{tabular}{ll}
\hline Methods & RCT. \\
\hline Participants & $\begin{array}{l}\text { Participants, } \geq 70 \text { years of age, from } 6 \text { general practices in Hoensbroek, who had reported } \\
\text { two or more falls in the previous } 6 \text { months or had scored } 3 \text { or more on the mobility control } \\
\text { scale of the short version of the sickness impact profile. } \\
\mathrm{n}=159 \text { (I). } \\
(\mathrm{n}=138 \text { received standard intervention programme; } \mathrm{n}=21 \text { did not receive standard } \\
\text { intervention programme). } \\
\mathrm{n}=157 \text { (C). }\end{array}$ \\
\hline Interventions & $\begin{array}{l}\text { Multifactorial intervention. Intervention group received } 5 \text { home visits by community nurse } \\
\text { over a period of } 1 \text { year. During home visits participants were screened for medical, envi- } \\
\text { ronmental and behavioural factors potentially influencing falls and mobility and followed } \\
\text { by advice, referrals and other actions aimed at dealing with observed hazards. The control } \\
\text { group did not receive any special attention or intervention on prevention of falls and im- } \\
\text { pairments in mobility. No details of any home modification given }\end{array}$ \\
\hline Outcomes & Falls \& injurious falls, collected at 12 and 18 months' follow-up \\
\hline Notes & Authors' judgement Support for judgement \\
\hline Bias of bias & Low risk \\
\hline
\end{tabular}

Vetter 1992

\begin{tabular}{ll}
\hline Methods & RCT. \\
\hline Participants & 70 years of age patients registered at a group practice of 5 general practitioners in a Welsh \\
& $\begin{array}{l}\text { market town. } \\
\mathrm{n}=350(\mathrm{I}) . \\
\mathrm{n}=324(\mathrm{C}) .\end{array}$
\end{tabular}


Vetter 1992 (Continued)

\begin{tabular}{|c|c|c|}
\hline Interventions & \multicolumn{2}{|c|}{$\begin{array}{l}\text { Intervention participants received intensive health visiting, over } 4 \text { years, to provide nutri- } \\
\text { tion advice and make medical and environmental checks environmental hazards included: } \\
\text { trailing wires, loose carpets, outside toilets, lighting levels and slippery slopes. Muscle tone } \\
\text { and fitness levels were addressed at physiotherapist-led classes. Health visitor visited as often } \\
\text { as believed to be necessary, carrying out referrals. Details concerning the control group are } \\
\text { not available }\end{array}$} \\
\hline Outcomes & \multicolumn{2}{|c|}{ Change in fracture rates, falls over a 4-year follow-up period } \\
\hline \multicolumn{3}{|l|}{ Notes } \\
\hline \multicolumn{3}{|l|}{ Risk of bias } \\
\hline Bias & Authors' judgement & Support for judgement \\
\hline Allocation concealment (selection bias) & Low risk & Adequate. \\
\hline
\end{tabular}

Watson 2005

\begin{tabular}{|c|c|c|}
\hline Methods & \multicolumn{2}{|l|}{ RCT. } \\
\hline Participants & \multicolumn{2}{|c|}{$\begin{array}{l}\text { Families with one or more children younger than } 5 \text { years, from the caseloads of participating } \\
\text { health visitors. Health visitors were recruited from working practices located in deprived } \\
\text { areas in the Nottingham Health Authority } \\
\mathrm{n}=1711 \text { families (I). } \\
\mathrm{n}=1717 \text { families (C). }\end{array}$} \\
\hline Interventions & \multicolumn{2}{|c|}{$\begin{array}{l}\text { Standardised safety consultation and provision of free safety equipment } \\
\text { Intervention comprised of a standard consultation on safety that had been adapted to con- } \\
\text { form to educational principles to increase the effectiveness. Consultation was individualised } \\
\text { and specific to children's ages in each family and took about } 20 \text { minutes. The health visitor } \\
\text { offered stair gates, fire guards, smoke alarms, cupboard locks and window locks free of } \\
\text { charge to low income families and these were fitted free of charge. Families not on a low } \\
\text { income were offered equipment at cost price and a delivery service to their home }\end{array}$} \\
\hline Outcomes & \multicolumn{2}{|c|}{$\begin{array}{l}\text { Medically attended injury over a two year follow-up period, and possession of safety equip- } \\
\text { ment collected at } 12 \text { and } 24 \text { months by postal questionnaire }\end{array}$} \\
\hline \multicolumn{3}{|l|}{ Notes } \\
\hline \multicolumn{3}{|l|}{ Risk of bias } \\
\hline Bias & Authors' judgement & Support for judgement \\
\hline Allocation concealment (selection bias) & Low risk & \\
\hline
\end{tabular}


Characteristics of excluded studies [ordered by study ID]

\begin{tabular}{|c|c|}
\hline Study & Reason for exclusion \\
\hline Assantachai 2002 & Community based with no home hazard intervention. \\
\hline Barnes 2004 & Trials of Improved Practices (TIPs) methodology. \\
\hline Binns 2004 & Study focused on reducing injuries related to chronic exposures \\
\hline Boreland 2006 & Study focused on reducing injuries related to chronic exposures \\
\hline Bouwen 2008 & No intervention that met inclusion criteria. \\
\hline Caplan 2004 & No intervention that met inclusion criteria. \\
\hline Carman 2006 & Evaluation study. \\
\hline Casteel 2004 & Controlled clinical trial. Allocation concealment unclear. \\
\hline Ciaschini 2009 & No intervention that met inclusion criteria. \\
\hline Clemson 1996 & Case-control study. \\
\hline Colver 1982 & Controlled clinical trial. Allocation concealment unclear. \\
\hline Conn 2005 & Non-controlled before and after study. Allocation concealment not used \\
\hline Dershewitz 1979 & Controlled clinical trial. Allocation concealment unclear. \\
\hline Diener 2005 & Controlled clinical trial. Allocation concealment unclear. \\
\hline Dixon 2009 & Controlled clinical trial. Allocation concealment unclear. \\
\hline Duff 2002 & Undefined access to home equipment with no measure of change to physical hazards \\
\hline Durongritichai 2003 & PRECEDE-PROCEED methodology with randomisation not described \\
\hline Fergusson 2005 & No intervention that met inclusion criteria. \\
\hline Filiatrault 2007 & Controlled clinical trial. Allocation concealment unclear. \\
\hline Gerson 2005 & Controlled clinical trial. Allocation concealment unclear. \\
\hline Gillespie-Bennett 2008 & Study focused on reducing injuries related to chronic exposures \\
\hline Ginnelly 2005 & Installation of smoke alarm sole intervention. \\
\hline Haynes 2003 & No intervention that met inclusion criteria. \\
\hline
\end{tabular}


(Continued)

\begin{tabular}{|c|c|}
\hline Hermann 1999 & German-language paper translated does not meet inclusion criteria \\
\hline Hornbrook 1994 & Controlled clinical trial. Allocation concealment unclear. \\
\hline Huang 2003 & No intervention to meet inclusion criteria. \\
\hline Huang 2004 & Controlled clinical trial. Allocation concealment unclear. \\
\hline Iwarsson 2009 & Survey study. \\
\hline Johnston 2000 & Controlled clinical trial. Allocation concealment unclear. \\
\hline Katcher 1989 & Controlled clinical trial. Allocation concealment unclear. \\
\hline Kelly 1987 & Controlled clinical trial. Allocation concealment unclear. \\
\hline Kendrick 2008 & Study protocol. \\
\hline Kerse 2004 & No intervention that met inclusion criteria. \\
\hline Laffoy 1997 & Case-control. \\
\hline Lamb 2008 & Survey study. \\
\hline Lannin 2007 & No intervention that met inclusion criteria. \\
\hline Lightbody 2002 & Controlled clinical trial. Allocation concealment unclear. \\
\hline Lin 2007 & Controlled clinical trial. Allocation concealment unclear. \\
\hline Llewellyn 2003 & No intervention that met inclusion criteria. \\
\hline McLean 1996 & Case-control. \\
\hline McMurdo 2000 & Environmental intervention was not undertaken. \\
\hline Minkovitz 2010 & No intervention that met inclusion criteria. \\
\hline Morgan 2005 & Evaluation study. \\
\hline Morgenstern 2000 & Stage 1: cohort. Stage 2: case-control. \\
\hline Nelson 2005 & No intervention that met inclusion criteria. \\
\hline Neno 2008 & No intervention that met inclusion criteria. \\
\hline Neyens 2009 & No intervention that met inclusion criteria. \\
\hline
\end{tabular}


(Continued)

\begin{tabular}{|c|c|}
\hline Northridge 1995 & Cohort. \\
\hline Odendaal 2009 & Controlled clinical trial. Allocation concealment unclear. \\
\hline Ozanne-Smith 2002 & Ecological study. Changes to hazards not reported at a household level \\
\hline Paul 1994 & Controlled clinical trial. Allocation concealment unclear. \\
\hline Peel 2000 & Controlled clinical trial. Allocation concealment unclear. \\
\hline Peeters 2007 & Study protocol. \\
\hline Petridou 1996 & Case-control. \\
\hline Petridou 1997 & Controlled clinical trial. Allocation concealment not used. \\
\hline Plautz 1996 & Interrupted time-series. Insufficient data gathering points. \\
\hline Poulstrop 2000 & Controlled before and after study. \\
\hline Pressley 2009 & No outcome that met inclusion criteria. \\
\hline Ramsey 2003 & No intervention that meets inclusion criteria. \\
\hline Rizawati 2008 & Cross-sectional study. \\
\hline Roberts 2004 & Installation of smoke alarm sole intervention. \\
\hline Robertson 2005 & Evaluation study. \\
\hline Robson 2003 & Controlled clinical trial. Allocation concealment unclear. \\
\hline Runyan 1992 & Case-control. \\
\hline Sattin 1998 & Case-control study. \\
\hline Schwarz 1993 & Controlled clinical trial. Allocation concealment not used. \\
\hline Schwebel 2009 & Observational study. \\
\hline Spiegel 1977 & Interrupted time-series. Insufficient data gathering points. \\
\hline Steinberg 2000 & Controlled clinical trial. Allocation concealment unclear. \\
\hline Stone 2007 & Controlled before and after study. Allocation concealment not used \\
\hline Studenski 1994 & Cohort study. \\
\hline
\end{tabular}


(Continued)

\begin{tabular}{|c|c|}
\hline Swart 2008 & Housing was not architect-designed or subject to housing regulations \\
\hline Sznajder 2003 & Controlled clinical trial. Allocation concealment unclear. \\
\hline Tanner 2003 & No outcome that met inclusion criteria. \\
\hline Thomas 1984 & Controlled clinical trial. Allocation concealment unclear. \\
\hline Thompson 1996 & Interrupted time series. Insufficient data gathering points. \\
\hline Tideiksaar 1990 & Interrupted time-series. No control group. \\
\hline Van Rijn 1991 & Case-control. \\
\hline Vind 2009 & No intervention that meets inclusion criteria. \\
\hline Wagner 1994 & Controlled clinical trial. Allocation concealment not used. \\
\hline Waller 1993 & Controlled clinical trial. Allocation concealment unclear. \\
\hline Weatherall 2004 & No intervention that meets inclusion criteria. \\
\hline Wyman 2007 & No intervention that meets inclusion criteria. \\
\hline Xia 2009 & Controlled clinical trial. Allocation concealment not used. \\
\hline Yang 2008 & Installation of smoke alarm sole intervention. \\
\hline Yates 2001 & Controlled clinical trial. Allocation concealment not used. \\
\hline Ytterstad 1996 & Controlled before and after study. Allocation concealment not used \\
\hline
\end{tabular}


DATA AND ANALYSES

Comparison 1. Multifactorial fall prevention intervention including: home hazard assessment and modification; medication review, bone and health assessment and exercise program, versus control

$\begin{array}{lllll}\text { Outcome or subgroup title } & \begin{array}{c}\text { No. of } \\ \text { studies }\end{array} & \begin{array}{c}\text { No. of } \\ \text { participants }\end{array} & \text { Statistical method } & \text { Effect size }\end{array}$

\begin{tabular}{lllll}
\hline 1 Falls & 2 & 901 & Risk Ratio (M-H, Random, 95\% CI) & $1.09[0.97,1.23]$ \\
\hline
\end{tabular}

Analysis I.I. Comparison I Multifactorial fall prevention intervention including: home hazard assessment and modification; medication review, bone and health assessment and exercise program, versus control, Outcome I Falls.

Review: Modification of the home environment for the reduction of injuries

Comparison: I Multifactorial fall prevention intervention including: home hazard assessment and modification; medication review, bone and health assessment and exercise program, versus control

Outcome: I Falls

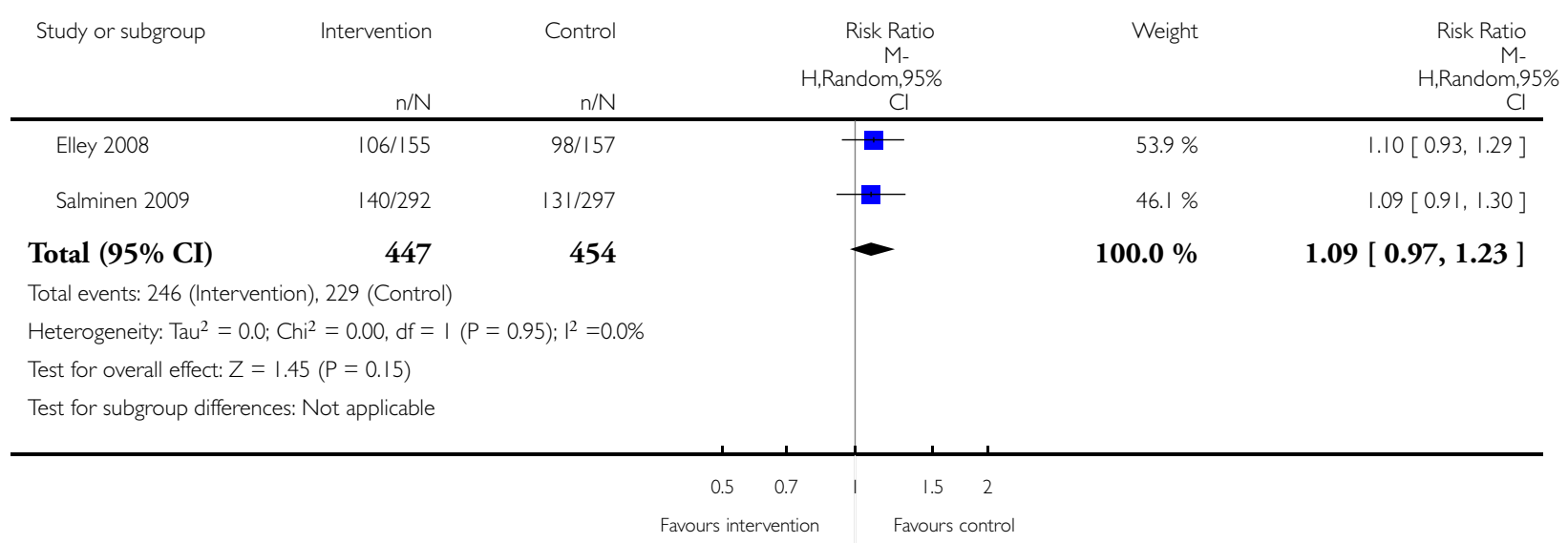


ADDITIONAL TABLES

Table 1. Children

\begin{tabular}{|c|c|c|c|c|}
\hline Study ID & Study Type & Intervention & Results & Reduction \\
\hline Babul 2007 & RCT & $\begin{array}{l}\text { Home visit plus safety kit or sa- } \\
\text { fety kit alone or control group }\end{array}$ & $\begin{array}{l}\text { Parents in both intervention } \\
\text { groups were more likely than } \\
\text { those in the control group to } \\
\text { report having their home hot } \\
\text { water temperature adjusted to } \\
\text { a safe level (safety kit alone } \\
\text { (OR } 2.21,95 \% \text { CI } 1.32 \text { to } \\
3.69) \& \text { safety kit plus home } \\
\text { visit (OR 2.6, 95\% CI } 1.57 \\
\text { to } 4.46 \text { ), both adjusted for in- } \\
\text { come and baseline measure of } \\
\text { dependent variable)) } \\
\text { Parents receiving a safety kit } \\
\text { plus home visit were more } \\
\text { likely to report having used the } \\
\text { hot water temperature-testing } \\
\text { card than those receiving the } \\
\text { safety kit alone (OR } 2.38,95 \% \\
\text { CI } 1.42-3.97 \text { ), adjusted for in- } \\
\text { come)) } \\
\text { Parents receiving a safety kit } \\
\text { plus home visit were also more } \\
\text { likely than those in the control } \\
\text { group to report having plants } \\
\text { placed out of reach of infants } \\
\text { (OR } 1.90,95 \% \text { CI } 1.03 \text { to } 3 \text {. } \\
52 \text { ), adjusted for income and } \\
\text { baseline measure of dependent } \\
\text { variable)) } \\
\text { However, no differences were } \\
\text { found in the levels of parent- } \\
\text { reported infant injuries } \\
\text { Difference in injury rates be- } \\
\text { tween kit group and control } \\
\text { group was OR = } 1.03 \text {, (95\% } \\
\text { CI } 0.49 \text { to } 2.18 \text { ), and dif- } \\
\text { ference between the kit plus } \\
\text { home visit group compared } \\
\text { to control group OR =1.05, } \\
\text { (95\% CI } 0.50 \text { to } 2.21 \text { ) }\end{array}$ & $\begin{array}{l}\text { Injury N } \\
\text { Falls NA } \\
\text { Hazards Y }\end{array}$ \\
\hline Clamp 1998 & RCT & GP safety advice & $\begin{array}{l}\text { Post intervention, interven- } \\
\text { tion group families used fire- } \\
\text { guards (RR } 1.89,95 \% \text { CI } 1.18 \\
\text { to } 2.94 \text { ), smoke alarms (RR1. } \\
14,95 \% \text { CI } 1.04 \text { to } 1.25 \text { ), }\end{array}$ & $\begin{array}{l}\text { Injury NA } \\
\text { Falls NA } \\
\text { Hazards Y }\end{array}$ \\
\hline
\end{tabular}




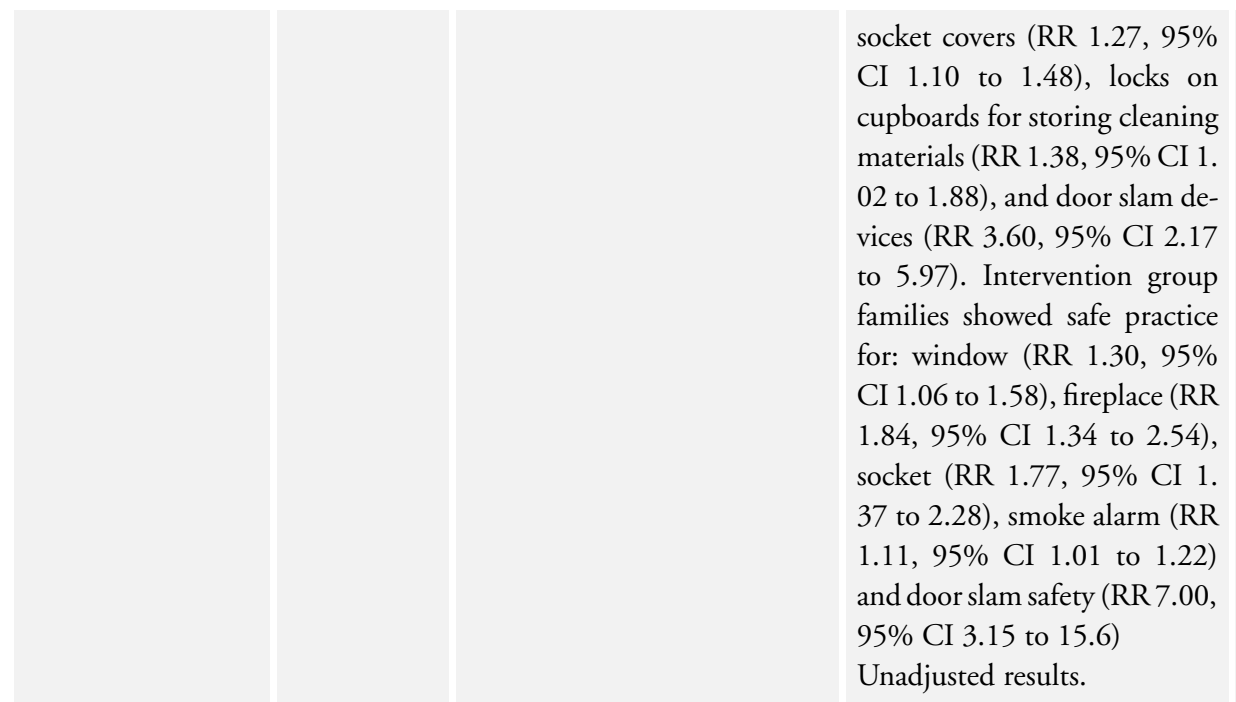

\begin{tabular}{|c|c|c|c|c|}
\hline Gielen 2002 & RCT & $\begin{array}{l}\text { Safety counselling by paedi- } \\
\text { atric residents, referral to chil- } \\
\text { dren's safety centre, plus home } \\
\text { visit }\end{array}$ & $\begin{array}{l}\text { No significant differences in } \\
\text { safety practices were found ob- } \\
\text { served between study groups } \\
\text { However, a sub-analysis, inde- } \\
\text { pendent of study group, found } \\
\text { that families who visited the } \\
\text { safety centre were significantly } \\
\text { more likely to have } 3 \text { or more } \\
\text { home safety practices observed } \\
\text { compared to families who di } \\
\text { not ( } 34 \% \text { vs } 17 \% \geq 3 \text {, 95\% } \\
\text { CI } 1.30 \text { to } 8.82 \text { ). Although } \\
\text { this analysis was adjusted for } \\
\text { exposure to safety councelling } \\
\text { and a home visit, and the au- } \\
\text { thors found no socio-demo- } \\
\text { graphic confounders; it was } \\
\text { based on non-randomised par- } \\
\text { ticipants and is therefore sus- } \\
\text { ceptible to confounders and } \\
\text { self selection bias }\end{array}$ & $\begin{array}{l}\text { Injury NA } \\
\text { Falls NA } \\
\text { Hazards N }\end{array}$ \\
\hline Hendrickson 2005 & RCT & $\begin{array}{l}\text { Counselling, assessment of } \\
\text { maternal safety practices and } \\
\text { provision of safety items. A } \\
\text { researcher counselled moth- } \\
\text { ers regarding hazards reported } \\
\text { during the first visit based on } \\
\text { Health Belief Model (HBM) } \\
\text { constructs }\end{array}$ & $\begin{array}{l}\text { A statistically significant dif- } \\
\text { ference was found in con- } \\
\text { trollable safety hazard (CHS) } \\
\text { scores between groups F ( } 1 \text {. } \\
77 \text { ) }=99.6, \mathrm{P}=0.00 \text {. As well } \\
\text { as having fewer observed haz- } \\
\text { ards, mothers receiving the in- } \\
\text { tervention indicated improved } \\
\text { self efficacy for home safety be- }\end{array}$ & $\begin{array}{l}\text { Injury NA } \\
\text { Falls NA } \\
\text { Hazards Y }\end{array}$ \\
\hline
\end{tabular}


Table 1. Children (Continued)

\begin{tabular}{|c|c|c|c|c|}
\hline & & & $\begin{array}{l}\text { haviours. All significant AN- } \\
\text { COVA findings occurred after } \\
\text { the intervention } \\
\text { Unadjusted results. }\end{array}$ & \\
\hline Kendrick 1999 & RCT & $\begin{array}{l}\text { Safety advice, low-cost safety } \\
\text { equipment and home visit }\end{array}$ & $\begin{array}{l}\text { No significant difference was } \\
\text { found in frequency of at least } \\
\text { one medically attended injury } \\
\text { (OR } 0.97,95 \% \text { CI } 0.72 \text { to } 1 \text {. } \\
30 \text { ), at least one attendance at } \\
\text { an accident and emergency de- } \\
\text { partment for injury (OR } 1.02 \text {, } \\
95 \% \text { CI } 0.76 \text { to } 1.37 \text { ), at least } \\
\text { one primary care attendance } \\
\text { for injury (OR } 0.75,95 \% \text { CI } \\
0.48 \text { to } 1.17 \text { ) or at least one } \\
\text { hospital admission for injury } \\
\text { (OR } 0.69,95 \% \text { CI } 0.42 \text { to } 1 . \\
12 \text { ) } \\
\text { Unadjusted results. }\end{array}$ & $\begin{array}{l}\text { Injury N } \\
\text { Falls NA } \\
\text { Hazards NA }\end{array}$ \\
\hline
\end{tabular}

\begin{tabular}{|c|c|c|c|c|}
\hline King 2005 & RCT & $\begin{array}{l}\text { Home hazards assessment, dis- } \\
\text { count coupons for safety de- } \\
\text { vices and information package }\end{array}$ & $\begin{array}{l}\text { Significant reduction in injury } \\
\text { visits per patient was shown in } \\
\text { the intervention group at } 12 \\
\text { months (RR } 0.69,95 \% \text { CI } 0 \text {. } \\
54 \text { to } 0.88 \text { ). However between } \\
12 \text { and } 36 \text { months the effect } \\
\text { appeared to diminish (RR } 0.8 \text {, } \\
95 \% \text { CI } 0.64 \text { to } 1.00) \\
\text { Significant reduction in the } \\
\text { observed prevalence of homes } \\
\text { without hot water ( }>54 \% \text { OR } \\
1.31,95 \% \text { CI } 1.14 \text { to } 1.50) \\
\text { and the presence of a fire ex- } \\
\text { tinguisher (OR } 0.81,95 \% \text { CI } \\
0.67 \text { to } 0.97 \text { ). Other changes } \\
\text { were small and non-significant } \\
\text { Self reported home safety } \\
\text { modifications were reported in } \\
62 \% \text { of intervention and } 23 \% \\
\text { of control homes (P < } 0.05 \text { ) } \\
\text { Unadjusted results. }\end{array}$ & $\begin{array}{l}\text { Injury Y } \\
\text { Falls NA } \\
\text { Hazards Y }\end{array}$ \\
\hline Posner 2004 & RCT & $\begin{array}{l}\text { Home } \\
\text { visit with structured home sa- } \\
\text { fety questionnaire caregivers of } \\
\text { those }<5 \text { years given compre- } \\
\text { hensive home safety education } \\
\text { and free safety devices }\end{array}$ & $\begin{array}{l}\text { At } 2 \text { months follow-up the } \\
\text { IG demonstrated significantly } \\
\text { higher average overall safety } \\
\text { scores than the CG ( } 73.3 \% \text {, } \\
\text { SD } 8.4 \%, P \leqq 0.002 \text { ), and sig- } \\
\text { nificant improvements in poi- }\end{array}$ & $\begin{array}{l}\text { Injury NA } \\
\text { Falls NA } \\
\text { Hazard reduction Y }\end{array}$ \\
\hline
\end{tabular}




\begin{tabular}{|c|c|c|c|c|}
\hline & & & $\begin{array}{l}\text { son }(74.4 \%, \mathrm{SD} 19.5, \mathrm{P} \leqq 0 \text {. } \\
02) \text {, cut/piercing }(81 \%, \mathrm{SD} 18 \text {. } \\
2, \mathrm{P} \leqq 0.001) \text { and burn cate- } \\
\text { gory scores ( } 76.0 \%, \mathrm{SD} 14.9 \text {, } \\
\mathrm{P}=0.03) \text {. Caregivers in the in- } \\
\text { tervention group also demon- } \\
\text { strated greater improvement in } \\
\text { reported use of the distributed } \\
\text { safety devices ( } 65.4 \%, \mathrm{SD} 20 \text {. } \\
5, \mathrm{P} \leqq 0.001) \\
\text { Unadjusted results. }\end{array}$ & \\
\hline Sangvai 2007 & RCT & $\begin{array}{l}\text { Multicomponent intervention } \\
\text { including focused counselling } \\
\text { from a physician and health as- } \\
\text { sistant, educational handouts, } \\
\text { phone follow-up, and access to } \\
\text { free safety devices and automo- } \\
\text { bile restraint evaluations }\end{array}$ & $\begin{array}{l}\text { At } 6 \text { months follow-up smoke } \\
\text { detectors were present and } \\
\text { functional in } 16 / 17 \text { interven- } \\
\text { tion households and } 5 / 10 \text { con- } \\
\text { trol }(\mathrm{P}=0.015) \text {; hazardous } \\
\text { substances not found in low } \\
\text { cupboards in } 13 / 16 \text { interven- } \\
\text { tion and } 3 / 10 \text { controls }(\mathrm{P}=0 \text {. } \\
015) \text {. However the study was } \\
\text { extremely underpowered with } \\
\text { only } 27 \text { home assessments } \\
\text { No significant difference in } \\
\text { medically attended injuries, } \\
19 / 160 \text { intervention, } 22 / 159 \\
\text { control } \\
\text { Unadjusted results. }\end{array}$ & $\begin{array}{l}\text { Injury N } \\
\text { Falls NA } \\
\text { Hazards Y }\end{array}$ \\
\hline Watson 2005 & RCT & $\begin{array}{l}\text { Standardised safety consulta- } \\
\text { tion and provision of free sa- } \\
\text { fety equipment }\end{array}$ & $\begin{array}{l}\text { At } 24 \text { months follow up the at- } \\
\text { tendance rate for injury in pri- } \\
\text { mary care was higher }(37 \%) \\
\text { for children in intervention } \\
\text { than in the control arm (IRR } \\
1.37,95 \% \text { CI } 1.11 \text { to } 1.70 \text {, } \\
P=0.003 \text { ). Treatment arms } \\
\text { did not differ significantly for } \\
\text { other injury outcomes } \\
\text { At both one and two years fol- } \\
\text { low up, families in the inter- } \\
\text { vention arm were significantly } \\
\text { more likely to have a range of } \\
\text { safety practices } \\
\text { The intervention arm were sig- } \\
\text { nificantly more likely to be safe } \\
\text { in terms of stairs (OR } 1.46 \text {, } \\
95 \% \text { CI } 1.19 \text { to } 1.80, P=0 . \\
0004) \text {, smoke alarms (OR } 1 .\end{array}$ & $\begin{array}{l}\text { Injury N } \\
\text { Falls NA } \\
\text { Hazards Y }\end{array}$ \\
\hline
\end{tabular}




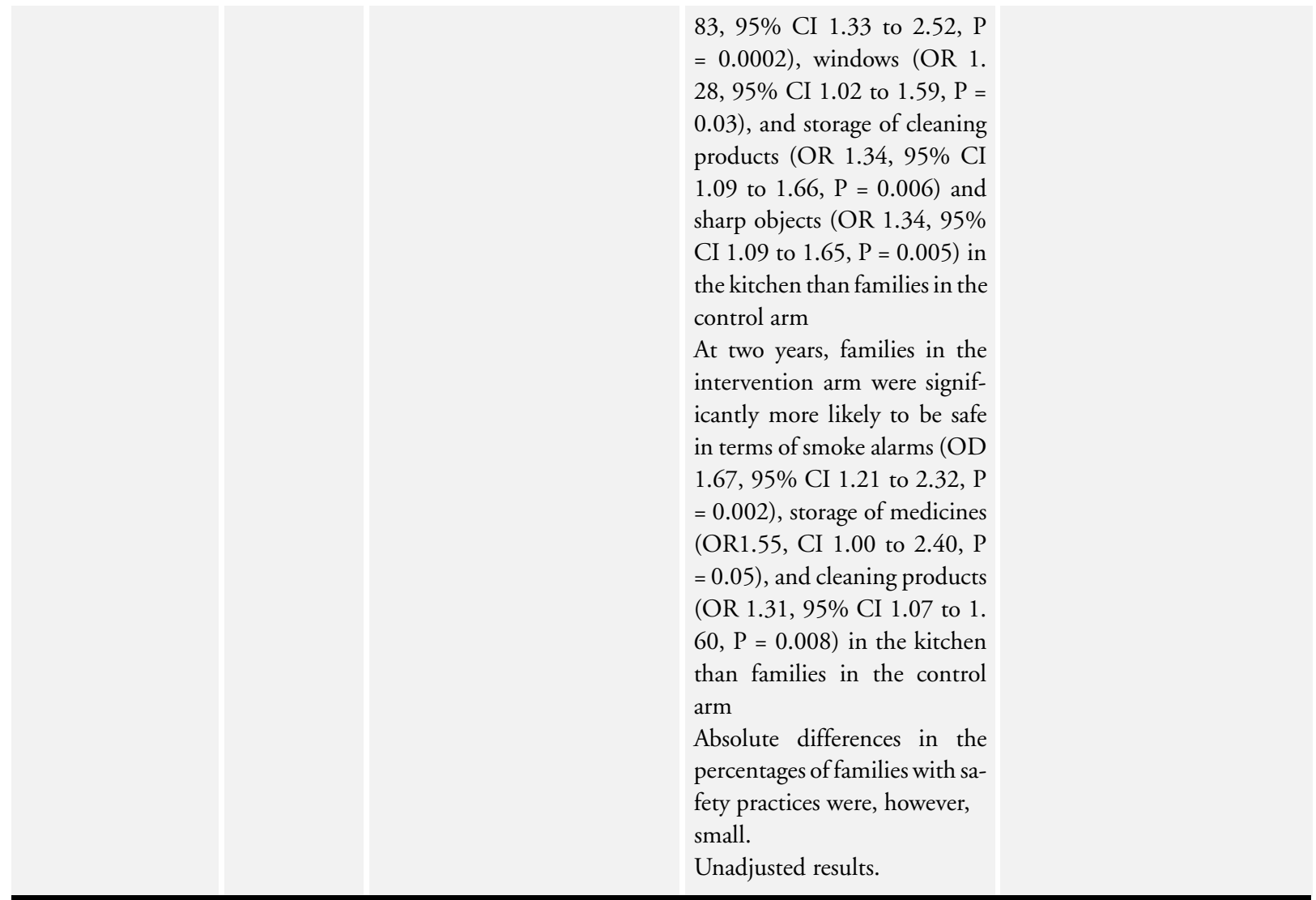

Table 2. Older people

\begin{tabular}{|c|c|c|c|c|}
\hline Study ID & Study Type & Intervention & Results & Reduction \\
\hline Becker 2003 & RCT & $\begin{array}{l}\text { Staff and resident educa- } \\
\text { tion on fall prevention, ad- } \\
\text { vice on environmental adap- } \\
\text { tations, progressive balance } \\
\text { and resistance training and } \\
\text { hip protectors }\end{array}$ & $\begin{array}{l}\text { Incidence density rate of falls } \\
\text { was reduced (RR } 0.55,95 \% \\
\text { CI } 0.41 \text { to } 0.73 \text { ). No signif- } \\
\text { icant difference was seen for } \\
\text { hip fractures. Lack of vali- } \\
\text { dated scoring meant no haz- } \\
\text { ard reduction was recorded } \\
\text { Unadjusted results. }\end{array}$ & $\begin{array}{l}\text { Injury N } \\
\text { Falls Y } \\
\text { Hazards NA }\end{array}$ \\
\hline Campbell 2005 & RCT & $\begin{array}{l}\text { Home sa- } \\
\text { fety assessment and modifica- } \\
\text { tion programme, home exer- } \\
\text { cise programme plus vitamin } \\
\text { D supplementation, both in- } \\
\text { terventions, or social visits }\end{array}$ & $\begin{array}{l}90 \% \text { of the home safety } \\
\text { group participants }(152 / 169) \\
\text { reported as complying par- } \\
\text { tially or completely with one } \\
\text { or more recommendations } \\
\text { made by the occupational } \\
\text { therapist }\end{array}$ & $\begin{array}{l}\text { Injury } \mathrm{Y} \\
\text { Falls } \mathrm{Y} \\
\text { Hazards } \mathrm{N}^{*}\end{array}$ \\
\hline
\end{tabular}


Table 2. Older people (Continued)

\begin{tabular}{|c|c|c|c|c|}
\hline & & & $\begin{array}{l}\text { Fewer falls occurred in the } \\
\text { group randomised to receive } \\
\text { the home safety programme } \\
\text { only, compared to the social } \\
\text { visits group (IRR } 0.39,95 \% \\
\text { CI } 0.24 \text { to } 0.62 \text { ) } \\
\text { Although a conservative anal- } \\
\text { ysis showed neither interven- } \\
\text { tion was effective in reduc- } \\
\text { ing injuries from falls, when } \\
\text { the home safety programme } \\
\text { group was analysed in a sin- } \\
\text { gle comparison against the so- } \\
\text { cial visit group, the home sa- } \\
\text { fety programme was shown to } \\
\text { significantly reduce injurious } \\
\text { falls (IRR } 0.56,95 \% \text { CI } 0.36 \\
\text { to } 0.87 \text { ) } \\
\text { *Although a reduction in haz- } \\
\text { ards was observed in the inter- } \\
\text { vention group, no statistical } \\
\text { significance test was reported } \\
\text { Unadjusted results. }\end{array}$ & \\
\hline Carter (unpublished) & RCT & $\begin{array}{l}\text { Home visit to assess hazards } \\
\text { followed by action plan. }\end{array}$ & $\begin{array}{l}\text { The proportion of partici- } \\
\text { pants who reported falling } \\
\text { did not differ significantly be- } \\
\text { tween control group (CG) } \\
\text { and either of the intervention } \\
\text { groups (IG): brief interven- } \\
\text { tion (OR } 0.6,95 \% \text { CI } 0.3 \text { to } \\
1.1 \text { ) and intensive interven- } \\
\text { tion (OR } 0.8,95 \% \text { CI } 0.4 \text { to } \\
1.4) \\
\text { The proportion of partici- } \\
\text { pants who reported one or } \\
\text { more falls resulting in medical } \\
\text { attention did not differ signif- } \\
\text { icantly between control group } \\
\text { (CG) and either of the inter- } \\
\text { vention groups (IG): brief in- } \\
\text { tervention, (OR } 0.7,95 \% \text { CI } \\
0.2 \text { to } 2.2 \text { ) and intensive in- } \\
\text { tervention (OR } 0.7,95 \% \text { CI } \\
0.2 \text { to } 2.4 \text { ) } \\
\text { The proportion of older peo- } \\
\text { ple falling in and around their } \\
\text { homes was not significantly }\end{array}$ & $\begin{array}{l}\text { Injury N } \\
\text { Falls } N \\
\text { Hazards } Y^{*}\end{array}$ \\
\hline
\end{tabular}


Table 2. Older people (Continued)

\begin{tabular}{|c|c|c|}
\hline & & $\begin{array}{l}\text { different between the control } \\
\text { group and either of the inter- } \\
\text { vention groups } \\
\text { A significant association was } \\
\text { found between intervention } \\
\text { and control groups to im- } \\
\text { prove home safety with the } \\
\text { brief ( } 35 \%) \text { and the in- } \\
\text { tensive intervention ( } 49 \%) \\
\text { groups compared to the con- } \\
\text { trol group ( } 28 \%) \text { over a } 12- \\
\text { month follow-up } \\
\text { *Although a significant re- } \\
\text { duction in hazards is reported, } \\
\text { no statistical significance test } \\
\text { was reported } \\
\text { Unadjusted results. }\end{array}$ \\
\hline
\end{tabular}

\begin{tabular}{|c|c|c|c|c|}
\hline Close 1999 & RCT & $\begin{array}{l}\text { Home visit to identify haz- } \\
\text { ards. }\end{array}$ & $\begin{array}{l}\text { Risk of falling was signif- } \\
\text { icantly reduced in the in- } \\
\text { tervention group (OR } 0.39 \text {; } \\
95 \% \text { CI } 0.23 \text { to } 0.66 \text { ), as was } \\
\text { risk of recurrent falls (OR } 0 \text {. } \\
33 \text {; } 95 \% \text { CI } 0.16 \text { to } 0.68 \text { ) } \\
\text { No significant reductions in } \\
\text { the percentage of patients re- } \\
\text { porting serious injury from } \\
\text { falls was found (CG } 8 \% \text { ver- } \\
\text { sus IG } 4 \%, P=0.26 \text { ) } \\
\text { Unadjusted results. }\end{array}$ & $\begin{array}{l}\text { Injury N } \\
\text { Falls Y } \\
\text { Hazards NA }\end{array}$ \\
\hline
\end{tabular}

\begin{tabular}{|c|c|c|c|c|}
\hline Cumming 1999 & RCT & $\begin{array}{l}\text { Home visit to record hazards } \\
\text { and facilitate modifications. }\end{array}$ & $\begin{array}{l}\text { Hazard percentage of homes } \\
\text { with modifications recom- } \\
\text { mended; compliance at } 12 \\
\text { months: } \\
\text { Remove mats/rugs: } 48 \% \text {; } \\
49 \% \\
\text { Change footwear: } 24 \% ; 54 \% \\
\text { Non-slip mats: } 21 \% ; 75 \% \\
\text { Change behaviour: } 15 \% \text {; } \\
60 \% \\
\text { Night light: } 13 \% ; 58 \% \\
\text { Stair rails: } 12 \% \text {; } 19 \% \\
\text { Remove electrical cords: } \\
12 \% \text {; } 67 \% \\
\text { Falls were reduced in the in- } \\
\text { tervention subgroup with a } \\
\text { history of falls (RR } 0.64,95 \%\end{array}$ & $\begin{array}{l}\text { Injury NA } \\
\text { Falls Y } \\
\text { Hazards N* }\end{array}$ \\
\hline
\end{tabular}


Table 2. Older people (Continued)

\begin{tabular}{|c|c|c|c|c|}
\hline & & & $\begin{array}{l}\text { CI } 0.50 \text { to } 0.83 \text { ) } \\
{ }^{*} \text { Although a reduction in haz- } \\
\text { ards was observed in the inter- } \\
\text { vention group, no statistical } \\
\text { significance test was reported } \\
\text { Unadjusted results. }\end{array}$ & \\
\hline Day 2002 & RCT & $\begin{array}{l}\text { Multifactorial } \\
\text { intervention including home } \\
\text { hazards management }\end{array}$ & $\begin{array}{l}\text { The percentage estimated re- } \\
\text { duction in annual fall rate at- } \\
\text { tributed to home hazard man- } \\
\text { agement was not significant } \\
(3.1 \%, 95 \% \text { CI }-2.0 \text { to } 9.7) \text {. } \\
\text { There was a significant effect } \\
\text { when combined with exercise } \\
\text { (9.9\%, } 95 \% \text { CI } 2.4 \text { to } 17.9) \\
\text { and the strongest effect was } \\
\text { observed when all three inter- } \\
\text { ventions; exercise, home haz- } \\
\text { ard management, vision cor- } \\
\text { rection, were combined to- } \\
\text { gether ( } 14.0 \%, 95 \% \text { CI } 3.7 \text { to } \\
22.6) \text { (RR } 0.67,95 \% \text { CI } 0.51 \\
\text { to } 0.88) \\
543 \text { participants receiving the } \\
\text { home hazard management in- } \\
\text { tervention } 478 \text { were advised } \\
\text { to have modifications to their } \\
\text { homes. } 363 \text { received help to } \\
\text { do these modifications which } \\
\text { included } 275 \text { hand rails fitted, } \\
72 \text { modifications to floor cov- } \\
\text { erings and } 72 \text { homes receiving } \\
\text { contrast edging to steps } \\
\text { Unadjusted results. } \\
* \text { Although hazards were re- } \\
\text { duced in the intervention } \\
\text { homes, no statistical signifi- } \\
\text { cance test was reported }\end{array}$ & $\begin{array}{l}\text { Injury NA } \\
\text { Falls Y } \\
\text { Hazards N* }\end{array}$ \\
\hline Elley, 2008 & RCT & $\begin{array}{l}\text { Multicomponent inter- } \\
\text { vention. Home-based nurse } \\
\text { assessment of falls and frac- } \\
\text { ture risk factors and home } \\
\text { hazards, referral to appropri- } \\
\text { ate community interventions, } \\
\text { and strength and balance ex- } \\
\text { ercise programme }\end{array}$ & $\begin{array}{l}\text { The incidence rate ratio for } \\
\text { falls for intervention group } \\
\text { compared with the control } \\
\text { group, over the } 12 \text { month } \\
\text { follow-up period, was } 0.96 \\
\text { ( } 95 \% \text { CI } 0.7-1.34 \text { ) } \\
\text { There was no significant dif- } \\
\text { ference in } \\
\text { secondary outcomes between } \\
\text { the two groups }\end{array}$ & $\begin{array}{l}\text { Injury N } \\
\text { Falls N } \\
\text { Hazards NA }\end{array}$ \\
\hline
\end{tabular}


Table 2. Older people (Continued)

Unadjusted results.

\begin{tabular}{|c|c|c|c|c|}
\hline Gitlin 2006 & RCT & $\begin{array}{l}\text { Multicomponent } \\
\text { intervention involving home } \\
\text { modifications and training in } \\
\text { their use, instruction in strate- } \\
\text { gies of problem solving, en- } \\
\text { ergy conservation, safe perfor- } \\
\text { mance, and fall recovery tech- } \\
\text { niques; and balance and mus- } \\
\text { cle strength training }\end{array}$ & $\begin{array}{l}\text { Fewer home hazards were ob- } \\
\text { served in the intervention } \\
\text { group than in the control } \\
\text { group } \\
\text { The difference of adjusted } \\
\text { means for environmental haz- } \\
\text { ards at } 6 \text { months was - } 1.53 \text { (P } \\
=0.05 \text { ) which appears non-ef- } \\
\text { fective } \\
\text { The difference of adjusted } \\
\text { means for environmental haz- } \\
\text { ards at } 12 \text { months was }-1.38 \text {, } \\
\text { ( } 95 \% \text { CI -3.17 to } 0.41 \text {, P = } \\
0.13 \text { ) which was non-signifi- } \\
\text { cant } \\
\text { In both, the difference of ad- } \\
\text { justed means were adjusted } \\
\text { for race, living arrangements, } \\
\text { number of recent fallers and } \\
\text { near falls, and perceived abil- } \\
\text { ity to manage fall risks and } \\
\text { control falling and health } \\
\text { conditions }\end{array}$ & $\begin{array}{l}\text { Injury NA } \\
\text { Falls NA } \\
\text { Hazards N }\end{array}$ \\
\hline
\end{tabular}

\begin{tabular}{|c|c|c|c|}
\hline Hendricks 2008 & RCT & $\begin{array}{l}333 \text { com- } \\
\text { munity dwelling Dutch peo- } \\
\text { ple aged } 65 \text { and over who were } \\
\text { seen in an emergency depart- } \\
\text { ment after a fall. Participants } \\
\text { were also recruited from the } \\
\text { GP Cooperative }\end{array}$ & $\begin{array}{l}\text { No significant differences be- } \\
\text { tween the two groups were } \\
\text { observed in terms of falls } \\
\text { At least one fall: } 4 \text { months } \\
\text { (OR } 1.36,95 \% \text { CI } 0.77 \text { to } 2 \text {. } \\
41,(\mathrm{P}=0.29)), 12 \text { months } \\
\text { (OR } 0.86(0.50 \text { to } 1.49) \mathrm{P}= \\
0.59) \\
\text { More than } 1 \text { fall: } 4 \text { months } \\
(\text { OR } 0.91,95 \% \text { CI } 0.39 \text { to } \\
2.11(\mathrm{P}=0.83)), 12 \text { months } \\
(\mathrm{OR} 0.95,95 \% \text { CI } 0.51 \text { to } 1 . \\
78(\mathrm{P}=0.87)) \\
\text { injurious falls: } 4 \text { months (OR } \\
0.79,95 \% \text { CI } 0.31-2.0,(\mathrm{P}= \\
0.62)), 12 \text { months }(\mathrm{OR} 0.77 \text {, } \\
95 \% \text { CI } 0.35-1.73,(\mathrm{P}=0.53) \\
\text { ) } \\
\text { Unadjusted results. }\end{array}$ \\
\hline
\end{tabular}

Injury $\mathrm{N}$

Falls N

Hazards NA

seen in an emergency depart- At least one fall: 4 months 41, $(\mathrm{P}=0.29)), 12$ months (OR 0.86 (0.50 to 1.49$) \mathrm{P}=$ More than 1 fall: 4 months (OR $0.91,95 \%$ CI 0.39 to $2.11(\mathrm{P}=0.83)), 12$ months to 1. $0.79,95 \%$ CI $0.31-2.0$, ( $\mathrm{P}=$ $95 \%$ CI $0.35-1.73,(\mathrm{P}=0.53)$

Unadjusted results.

Home visit to assess environmental risk factors followed by treatment plan
No significant differences be- Injury NA tween the control and inter- Falls $\mathrm{N}$ vention groups in the cumula- Hazards NA 
Table 2. Older people (Continued)

\begin{tabular}{|c|c|c|c|c|}
\hline & & & $\begin{array}{l}\text { tive number of falls ( } 311 \text { ver- } \\
\text { sus } 241, \mathrm{P}=0.34), \text { having one } \\
\text { or more falls }(79.2 \% \text { versus } \\
72.0 \%, \mathrm{P}=0.30) \text { or in the } \\
\text { mean number of falls ( } 4.0 \text { ver- } \\
\text { sus } 3.2, \mathrm{P}=0.43 \text { ) } \\
\text { Unadjusted results. }\end{array}$ & \\
\hline Jensen 2002 & RCT & $\begin{array}{l}\text { Multifactorial fall prevention } \\
\text { programme comparing staff } \\
\text { education, environmental ad- } \\
\text { justment, exercise, drug re- } \\
\text { views, aids, hip protectors and } \\
\text { post fall problem solving con- } \\
\text { ferences }\end{array}$ & $\begin{array}{l}\text { An interdisciplinary and mul- } \\
\text { tifactorial prevention pro- } \\
\text { gramme targeting residents, } \\
\text { staff and the environment } \\
\text { may reduce falls and femoral } \\
\text { fractures } \\
\text { During the } 34 \text {-week follow- } \\
\text { up period, } 44 \% \text { of residents } \\
\text { in the intervention group sus- } \\
\text { tained a fall compared with } \\
56 \% \text { in the control group (RR } \\
0.78 \text {, } 95 \% \text { CI, } 0.64 \text { to } 0 . \\
96 \text { ). The odds ratio adjusted } \\
\text { for baseline factors was } 0.49 \\
\text { (95\% CI } 0.37 \text { to } 0.65 \text { ), and } \\
\text { the incidence rate ratio of falls } \\
\text { adjusted for baseline factors } \\
\text { was } 0.60 \text { ( } 95 \% \text { CI } 0.50 \text { to } 0 . \\
73 \text { ). Three people in the in- } \\
\text { tervention group and } 12 \text { peo- } \\
\text { ple in the control group had } \\
\text { a fracture to the femur (ad- } \\
\text { justed odds ratio, } 0.23 \text { (CI } 0 . \\
06 \text { to } 0.94 \text { )) } \\
\text { In a later report (Jensen } 2003 \text { ) } \\
\text { the effect of this intervention } \\
\text { in older people with differing } \\
\text { levels of cognitive function } \\
\text { was investigated. } 59 \text { minor, } \\
\text { moderate or serious injuries } \\
\text { occurred in the higher cog- } \\
\text { nitive group (IRR } 0.9 \text {, } 95 \% \\
\text { CI } 0.5 \text { to } 1.5 \text { ) compared with } \\
\text { the control group and sim- } \\
\text { ilarly in the lower cognitive } \\
\text { group (IRR } 0.9,95 \% \text { CI } 0.5 \\
\text { to } 1.3 \text { ). However in the lower } \\
\text { cognitive group the } 171 \text { par- } \\
\text { ticipants sustained } 10 \text { femoral } \\
\text { fractures, all of which were in } \\
\text { the control group (P = } 0.006 \text { ) }\end{array}$ & $\begin{array}{l}\text { Injury Y } \\
\text { Falls Y } \\
\text { Hazard NA }\end{array}$ \\
\hline
\end{tabular}


Table 2. Older people (Continued)

\begin{tabular}{|c|c|c|c|c|}
\hline Mahoney 2007 & RCT & $\begin{array}{l}\text { Home visits to assess falls risk } \\
\text { factors, recommendations to } \\
\text { participant and physician, ex- } \\
\text { ercise plan, and } 11 \text { monthly } \\
\text { telephone calls }\end{array}$ & $\begin{array}{l}\text { There was no difference in } \\
\text { rate of falls between the in- } \\
\text { tervention and control groups } \\
\text { (RR } 0.81, \mathrm{P}=0.27 \text { ) } \\
\text { Nursing home days were } \\
\text { fewer in the intervention } \\
\text { group (10.3 vs } 20.5 \text { days, } \mathrm{P}= \\
0.04) \\
\text { Intervention subjects with a } \\
\text { Mini-Mental State Examina- } \\
\text { tion (MMSE) score of } 27 \text { or } \\
\text { less had a lower rate of falls } \\
\text { (RR 0.55; P = 0.05) and, if } \\
\text { they lived with someone, had } \\
\text { fewer hospitalisations (RR } 0 . \\
44, \mathrm{P}=0.05 \text { ), nursing home } \\
\text { admissions (RR } 0.15 \text {, P = . } \\
003 \text { ), and nursing home days } \\
\text { ( } 7.5 \text { vs } 58.2, \mathrm{P}=.008) \\
\text { Unadjusted results. }\end{array}$ & $\begin{array}{l}\text { Injury NA } \\
\text { Falls N } \\
\text { Hazard NA }\end{array}$ \\
\hline Nikolaus 2003 & RCT & $\begin{array}{l}\text { Home visit with advice about } \\
\text { environmental hazards, offer } \\
\text { of facilities to change them } \\
\text { and training in the use of mo- } \\
\text { bility and technical aids }\end{array}$ & $\begin{array}{l}\text { Intervention group had } 31 \% \\
\text { fewer falls than control group } \\
\text { (IRR } 0.69,95 \% \text { CI } 0.51 \text { to } 0 \text {. } \\
97 \text { ). } \\
\text { Study not designed to exam- } \\
\text { ine fall related injuries. } \\
\text { Compliance rate of } 75.7 \% \\
\text { with at least one recom- } \\
\text { mended hazard change. } \\
\text { Participants who made at least } \\
\text { one recommendation experi- } \\
\text { enced a significant reduction } \\
\text { in the rate of falls (IRR } 0.64 \text {; } \\
95 \% \text { CI } 0.37 \text { to } 0.99 \text { ). } \\
\text { The number of falls in those } \\
\text { in the intervention group } \\
\text { with no modifications was not } \\
\text { significantly different from } \\
\text { those in the control group } \\
\text { (IRR, } 1.05,95 \% \text { CI } 0.82 \text { to } \\
1.41 \text { ) } \\
\text { Unadjusted results. } \\
* \text { Although hazards were re- } \\
\text { duced in the intervention } \\
\text { homes, no statistical signifi- } \\
\text { cance test was reported }\end{array}$ & $\begin{array}{l}\text { Injury NA } \\
\text { Falls Y } \\
\text { Hazards N* }\end{array}$ \\
\hline
\end{tabular}


Table 2. Older people (Continued)

\begin{tabular}{|c|c|c|c|c|}
\hline Pardessus 2002 & RCT & $\begin{array}{l}\text { Home visit that assessed en- } \\
\text { vironmental hazards and rec- } \\
\text { ommended modifications }\end{array}$ & $\begin{array}{l}\text { Rate of falls, hospitalisation } \\
\text { for falls were not significantly } \\
\text { different between the two } \\
\text { groups } \\
\text { Unadjusted results. }\end{array}$ & $\begin{array}{l}\text { Injury N } \\
\text { Falls N } \\
\text { Hazards NA }\end{array}$ \\
\hline Salminen 2009 & RCT & $\begin{array}{l}\text { 12-month fall pre- } \\
\text { vention programme based on } \\
\text { individual risk analysis; geri- } \\
\text { atric assessment, counselling } \\
\text { and guidance in fall pre- } \\
\text { vention, home hazard assess- } \\
\text { ment, group physical exer- } \\
\text { cise, home exercise, lectures } \\
\text { in groups and psychosocial } \\
\text { groups }\end{array}$ & $\begin{array}{l}\text { The intervention did not re- } \\
\text { duce the incidence of falls } \\
\text { overall (IRR for I vs C } 0.92 \text {, } \\
95 \% \text { CI }=0.72 \text { to } 1.19 \text { ) or } \\
\text { the incidence of falls requiring } \\
\text { medical treatment (IRR } 0.87 \text {, } \\
95 \% \text { CI } 0.63 \text { to } 1.21 \text { ). How- } \\
\text { ever in subgroup analysis, sig- } \\
\text { nificant interactions between } \\
\text { subgroups and groups (I and } \\
\text { C) were found for depressive } \\
\text { symptoms (P =.006), num- } \\
\text { ber of falls during previous } 12 \\
\text { months (P = .003), and self- } \\
\text { perceived risk of falling (P = . } \\
045 \text { ) } \\
\text { Unadjusted results. }\end{array}$ & $\begin{array}{l}\text { Injury N } \\
\text { Falls N } \\
\text { Hazards NA }\end{array}$ \\
\hline Shaw 2003 & RCT & $\begin{array}{l}\text { Multifactorial intervention } \\
\text { including medication review, } \\
\text { vision, blood pressure, mobil- } \\
\text { ity, footwear and an assess- } \\
\text { ment of home environmental } \\
\text { fall hazards and modification } \\
\text { using standard checklists }\end{array}$ & $\begin{array}{l}\text { No significant differences be- } \\
\text { tween two groups in propor- } \\
\text { tion who fell after } 1 \text { year or in } \\
\text { injuries sustained. } \\
\text { Compliance with hazard ad- } \\
\text { vice was } 41 / 105 \text { in interven- } \\
\text { tion group and } 8 / 111 \text { in con- } \\
\text { trol } \\
\text { Unadjusted results. } \\
{ }^{*} \text { Although hazards were re- } \\
\text { duced in the intervention } \\
\text { homes, no statistical signifi- } \\
\text { cance test was reported }\end{array}$ & $\begin{array}{l}\text { Injury } \mathrm{N} \\
\text { Falls } \mathrm{N} \\
\text { Hazards } \mathrm{N}^{*}\end{array}$ \\
\hline Stevens 2001 & RCT & $\begin{array}{l}\text { Home visit to assess hazards, } \\
\text { installation of free safety de- } \\
\text { vices and educational strategy }\end{array}$ & $\begin{array}{l}\text { No significant reduction in } \\
\text { the intervention group in the } \\
\text { incidence rate of falls involv- } \\
\text { ing environmental hazards in- } \\
\text { side the home (adjusted rate } \\
\text { ratio } 1.11 ; 95 \% \text { CI } 0.82 \text { to } 1 \text {. } \\
50 \text { ), or the rate of falls inside } \\
\text { the home (adjusted rate ratio } \\
1.17 \text {; } 95 \% \text { CI } 0.85 \text { to } 1.60 \text { ) } \\
\text { There was no significant re- }\end{array}$ & $\begin{array}{l}\text { Injury N } \\
\text { Falls N } \\
\text { Hazards Y }\end{array}$ \\
\hline
\end{tabular}


Table 2. Older people (Continued)

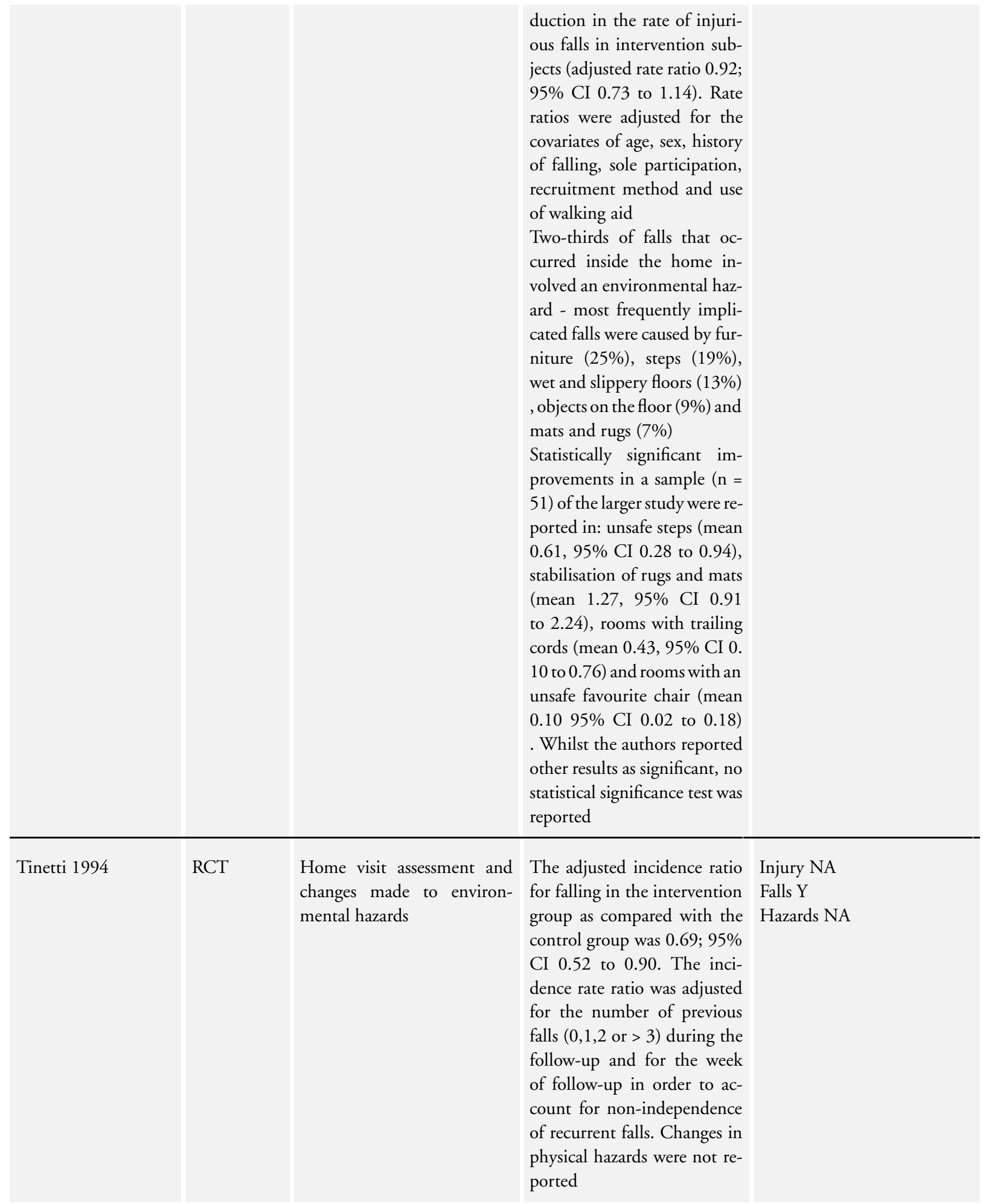


Table 2. Older people (Continued)

\begin{tabular}{|c|c|c|c|c|}
\hline van Haastregt 2000b & RCT & $\begin{array}{l}\text { Home visit screening for envi- } \\
\text { ronmental \& behavioural fac- } \\
\text { tors }\end{array}$ & $\begin{array}{l}\text { Odds ratios for the interven- } \\
\text { tion group for at least one fall } \\
\text { was } 1.3,95 \% \text { CI } 0.7 \text { to } 2.1 \\
\text { and for an injurious fall } 1.4 \text {, } \\
95 \% \text { CI } 0.8 \text { to } 2.6 \text {. Changes } \\
\text { in physical hazards were not } \\
\text { reported } \\
\text { Unadjusted results. }\end{array}$ & $\begin{array}{l}\text { Injury N } \\
\text { Falls N } \\
\text { Hazards NA }\end{array}$ \\
\hline Vetter 1992 & RCT & $\begin{array}{l}\text { Home visit to provide envi- } \\
\text { ronmental hazards check. }\end{array}$ & $\begin{array}{l}\text { Similar proportions of frac- } \\
\text { tures were observed in both } \\
\text { groups ( } 5 \% \text { (I) versus } 4 \%(\mathrm{C}) \\
\text { ). More falls without fracture } \\
\text { occurred in the intervention } \\
\text { group ( } 23 \% \text { (I) versus } 16 \% \\
\text { (C)). Stratifying by disability } \\
\text { there were more falls for all } \\
\text { disability levels in the inter- } \\
\text { vention group participants. } \\
\text { No results reported related } \\
\text { to changes in environmen- } \\
\text { tal hazards and no indication } \\
\text { of uptake/self reported falls } \\
\text { and injurious falls implemen- } \\
\text { tation } \\
\text { Unadjusted results. }\end{array}$ & $\begin{array}{l}\text { Injury N } \\
\text { Falls N } \\
\text { Hazards NA }\end{array}$ \\
\hline
\end{tabular}

\section{A P PENDICES}

\section{Appendix I. Search strategy}

The searches were based on the following strategy, developed in MEDLINE and adapted as appropriate to the specifications of each database. The strategy was deliberately designed to capture a broad range of references and the 'explode' feature was used wherever this was applicable to the database. There were no language restrictions.

- ASSIA (2004 to December 2009)

Search Query \#25 ((DE=(“accommodation" or “cottages" or "flats" or "houses" or "local authority housing” or "sheltered housing” or "buildings")) or(home) or(DE="ergonomics") or(DE="home environment") or(stair or staircase or stairwell) or(DE=("local authority housing" or "local authorities")) or(bedsit) or(maisonette* $)$ or (dwelling) ) and((DE=("accidents" or "burns" or "fractured" or "injuries" or "lesions" or "suffocation")) or(falls) or(DE="falls") or(falling) or(accident*)) (Copy Query) 
322 Published Works results found in Multiple Databases +

29,056 Scholars results found in COS Scholar Universe: Social Science

82 Web Sites results found in Web Resources Related to the Social Sciences/Humanities

Date Range: 2004 to 2009

- British Nursing Index (BNI) (1994 to December 2009)

(housing or house*).mp. (899)

2 (home or homes or abode*).mp. (6716)

3 accommodation*.mp. (163)

4 (residence* or residential).mp. (1180)

(apartment* or flat).mp. (23)

6 (building* or estate*).mp. (643)

7 (neighbourhood* or neighborhood $\left.^{*}\right) . \mathrm{mp} .(82)$

8 urban environment*.mp. (6)

9 buil* environment*.mp. (12)

10 ergonomic*.mp. (63)

11 local authorit*.mp. (141)

12 environment* design*.mp. (5)

13 living quarter*.mp. (3)

14 (staircase or stairs or stairwell).mp. (9)

15 exp housing/ (162)

16 exp Elderly Housing/ (158)

17 or/1-16 (8852)

18 exp Elderly : Accidents/ (549)

19 exp Children : Accidents/ (408)

20 (injury or injuries).mp. (2172)

21 (accident* or wound*).mp. (7717)

22 (fall* or scald* or burn*).mp. (1424)

23 (suffocat* or poison*).mp. (320)

24 exp Burns/ (285)

25 exp poisoning/ (200)

26 or/18-25 (10139)

$27 \quad 17$ and 26 (397)

28 limit 27 to $\mathrm{yr}=$ “2004 - 2009” (258)

- CINAHL (2004-December 2009) 


\begin{tabular}{|c|c|}
\hline Search ID\# & Search Terms \\
\hline S17 & (S9 and S16) \\
\hline S16 & $(\mathrm{S} 10$ or $\mathrm{S} 11$ or $\mathrm{S} 12$ or $\mathrm{S} 13$ or $\mathrm{S} 14$ or $\mathrm{S} 15)$ \\
\hline S15 & (MH “Accidental Falls") \\
\hline S14 & (MH “Fractures”) \\
\hline S13 & (MH “Burns”) \\
\hline S12 & (MH “Poisons") \\
\hline S11 & (MH “Accidents") \\
\hline S10 & (MH "Wounds and Injuries") \\
\hline S9 & $(\mathrm{S} 1$ or $\mathrm{S} 2$ or $\mathrm{S} 3$ or $\mathrm{S} 4$ or $\mathrm{S} 5$ or $\mathrm{S} 6$ or $\mathrm{S} 7$ or $\mathrm{S} 8)$ \\
\hline S8 & (“ergonomics”) or (MH “Ergonomics”) \\
\hline S7 & (MH "Home Environment") \\
\hline S6 & "neighbourhood" \\
\hline S5 & "apartment" \\
\hline S4 & “accommodation" \\
\hline S3 & "stairs" \\
\hline S2 & (MH “Residence (Omaha)”) \\
\hline S1 & (MH "Housing for the Elderly") or (MH "Public Housing") or (MH "Housing") \\
\hline
\end{tabular}

- Cochrane Library (2004-December 2009)

\begin{tabular}{ll} 
ID & Search \\
\hline$\# 1$ & MeSH descriptor Housing explode all trees \\
\hline$\# 2$ & MeSH descriptor Homes for the Aged explode all trees \\
\hline$\# 3$ & apartment
\end{tabular}




\begin{tabular}{|c|c|}
\hline \#4 & flat \\
\hline \#5 & accommodation \\
\hline \#6 & maisonette \\
\hline \#7 & home* \\
\hline$\# 8$ & ergonomics \\
\hline \#9 & stairs \\
\hline \#10 & stairway \\
\hline \#11 & staircase \\
\hline \#12 & local authority \\
\hline$\# 13$ & (\#1 OR \#2 OR \#3 OR \#4 OR \#5 OR \#6 OR \#7 OR \#8 OR \#9 OR \#10 OR \#11 OR \#12), from 2004 to 2009 \\
\hline \#14 & MeSH descriptor Wounds and Injuries explode all trees \\
\hline \#15 & MeSH descriptor Accidents explode all trees \\
\hline \#16 & MeSH descriptor Accidental Falls explode all trees \\
\hline \#17 & MeSH descriptor Fractures, Bone explode all trees \\
\hline \#18 & MeSH descriptor Burns explode all trees \\
\hline \#19 & (\#14 OR \#15 OR \#16 OR \#17 OR \#18), from 2004 to 2009 \\
\hline$\# 20$ & (\#13 AND \#19), from 2004 to 2009 \\
\hline
\end{tabular}

- EMBASE (1996 to 2009 Week 50)

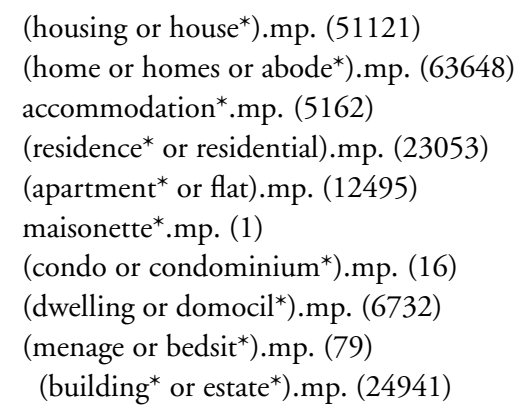


11 (neighbourhood* or neighborhood*).mp. (5520)

12 urban environment*.mp. (1053)

13 buil* environment*.mp. (343)

14 ergonomic*.mp. (4700)

15 local authorit*.mp. (675)

16 environment* design*.mp. (193)

17 living quarter*.mp. (32)

18 (staircase or stairs or stairwell).mp. (1702)

19 exp housing/ (3259)

20 exp home/ (3652)

21 or/1-20 (182349)

22 exp accident/ (42332)

23 exp accident prevention/ (4661)

24 exp accident proneness/ (333)

25 exp home accident/ (575)

26 (injury or injuries).mp. (336796)

27 (fall* or scald* or burn* or wound $\left.^{*}\right)$.mp. (152114)

28 exp fracture/ (63681)

29 (suffocat* $^{*}$ or poison*).mp. (22475)

30 poison/ (434)

31 exp fire/ (2195)

32 exp burn/ (15057)

33 or/22-32 (537720)

34 random\$.ti,ab. (314126)

35 factorial\$.ti,ab. (6755)

36 (crossover\$ or cross over\$ or cross-over\$).ti,ab. (24439)

37 placebo\$.ti,ab. (74183)

38 (doubl\$ adj blind\$).ti,ab. (51338)

39 (singl\$ adj blind\$).ti,ab. (4862)

40 assign\$.ti,ab. (82683)

41 allocat\$.ti,ab. (26205)

42 volunteer\$.ti,ab. (62897)

43 crossover procedure/ (18016)

44 double blind procedure/ (55904)

45 randomized controlled trial/ (147415)

46 single blind procedure/ (7826)

47 or/34-46 (491729)

48 limit 47 to human (391555)

4921 and 33 and 48 (1956)

50 limit 49 to $\mathrm{yr}=$ “2004 - 2009” (1093)

- ICONDA (1976 to December 2009)

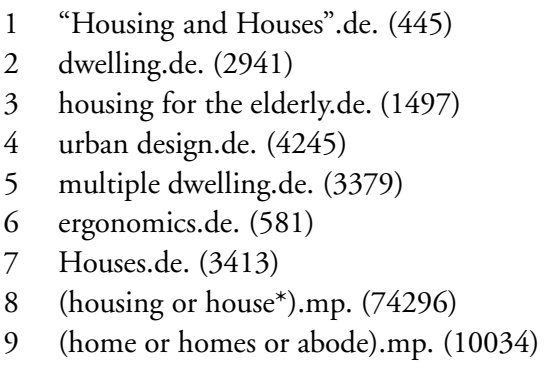


10 accommodation*.mp. (1932)

11 (residence* or residential).mp. (40396)

12 (apartment* or flat).mp. (15208)

13 (housing or house*).mp. (74296)

14 (condo or condominium*).mp. (237)

15 maisonette*.mp. (854)

16 living quarter*.mp. (75)

17 Neighbourhood.de. (842)

18 built environment.mp. (1559)

19 (staircase or stairs or stairwell).mp. (4154)

20 or/1-19 (113286)

21 (injury or injuries).mp. (1210)

22 (accident* or wound*).mp. (7428)

23 (scald* or burn*).mp. (3217)

24 (suffocat* or poison*).mp. (219)

25 fire.de. (4862)

26 poison.mp. (81)

27 safety.de. (6334)

28 (fall or falling or fell).mp. (2880)

29 or/21-28 (24079)

$30 \quad 20$ and 29 (2047)

31 limit 30 to $\mathrm{yr}=$ “2004 - 2009” (395)

- MEDLINE (1996 to November Week 3 2009)

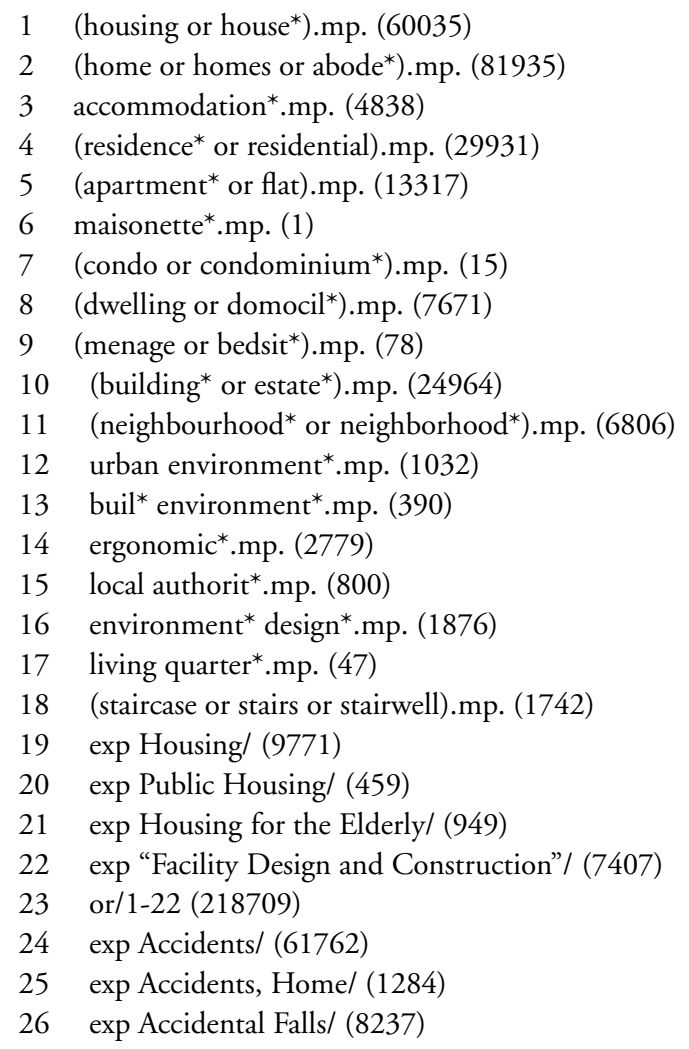


27 exp Accident prevention/ (31735)

28 exp "Wounds and Injuries"/ (235238)

29 (injury or injuries).mp. (270239)

30 (accident* $^{*}$ or wound*).mp. (145871)

31 (fall* or scald* or burn*).mp. (90653)

32 exp Fires/ (2801)

33 exp Burns/ (13774)

34 (suffocat* or poison*).mp. (27875)

35 Poisons/ (457)

36 or/24-35 (555186)

37 randomized controlled trial.pt. (181189)

38 controlled clinical trial.pt. (34294)

39 randomized.ab. (142722)

40 placebo.ab. (71399)

41 clinical trials as topic.sh. (62839)

42 randomly.ab. (98005)

43 trial.ab. (137623)

44 or/37-43 (452948)

45 exp animals/ not humans.sh. (1287604)

4644 not 45 (412042)

$47 \quad 23$ and 36 and 46 (1773)

48 limit 47 to $\mathrm{yr}=$ “2004 - 2009” (927)

\section{- Planex}

housing or house or home or homes or accommodation or residence* or residential or apartment* or flat or building AND

Injury or injuries or accident* or wound* or fall* or scald* or hazards

\section{- RIBA-British Architectural Library Catalogue}

housing or house or home or homes or accommodation or residence* or residential or apartment* or flat or building AND

Injury or injuries or accident* or wound* or fall* or scald* or hazards

\section{- SafetyLit}

Within SafetyLit search - Randomised controlled trial

- Web of Science

Search History

WoK Conference Proceedings Citation Index 


\begin{tabular}{|c|c|c|c|c|}
\hline Set & Results & & $\begin{array}{l}\text { Combine Sets } \\
\text { AND OR }\end{array}$ & Delete Sets \\
\hline$\# 28$ & 49 & $\begin{array}{l}\# 21 \text { or } \# 27 \\
\text { Databases }=\text { CPCI-S Timespan }=2004- \\
2009\end{array}$ & & \\
\hline \# 27 & 26 & $\begin{array}{l}\# 26 \text { and } \# 1 \\
\text { Databases=CPCI-S Timespan=2004- } \\
2009\end{array}$ & & \\
\hline \# 26 & 332 & $\begin{array}{l}\# 22 \text { or } \# 23 \text { or } \# 24 \text { or } \# 25 \\
\text { Databases }=\text { CPCI-S Timespan }=2004- \\
2009\end{array}$ & & \\
\hline$\# 25$ & 37 & $\begin{array}{l}\text { TS }=\text { (injury SAME home) } \\
\text { Databases }=\text { CPCI-S Timespan }=2004- \\
2009\end{array}$ & & \\
\hline \# 24 & 4 & $\begin{array}{l}\text { TS }=\text { (injury SAME house) } \\
\text { Databases }=\text { CPCI-S Timespan }=2004- \\
2009\end{array}$ & & \\
\hline \# 23 & 144 & $\begin{array}{l}\text { TS }=\left(\text { hazard }{ }^{*} \text { and house }{ }^{*}\right) \\
\text { Databases }=\text { CPCI-S Timespan }=2004 \text { - } \\
2009\end{array}$ & & \\
\hline$\# 22$ & 172 & $\begin{array}{l}\text { TS }=\left(\text { hazard }{ }^{*} \text { and } \text { home }^{*}\right) \\
\text { Databases }=\text { CPCI-S Timespan }=2004- \\
2009\end{array}$ & & \\
\hline \# 21 & 32 & $\begin{array}{l}\# 1 \text { and } \# 11 \text { and } \# 20 \\
\text { Databases }=C P C I-S \text { Timespan }=2004- \\
2009\end{array}$ & & \\
\hline
\end{tabular}




\begin{tabular}{l|l|}
$\# 20 \quad 6,163$ & $\begin{array}{l}\# 12 \text { or } \# 13 \text { or } \# 14 \text { or } \# 15 \text { or } \# 16 \text { or } \\
\# 17 \text { or } \# 18 \text { or } \# 19 \\
\text { Databases }=\text { CPCI-S Timespan }=2004- \\
2009\end{array}$ \\
\hline
\end{tabular}

\begin{tabular}{l|l}
$\# 19 \quad 10$ & $\begin{array}{l}\text { TS }=(\text { ("Thermal Burns") } \\
\text { Databases }=C P C I-S \text { Timespan }=2004- \\
2009\end{array}$
\end{tabular}

\begin{tabular}{l|l}
$\# 18 \quad 4,060$ & $\begin{array}{l}\text { TS=(injuries) } \\
\text { Databases }=C P C I-S \text { Timespan }=2004- \\
2009\end{array}$ \\
\hline
\end{tabular}

\begin{tabular}{l|l}
\hline$\# 170$ & $\begin{array}{l}\text { TS=("accidental burn") } \\
\text { Databases }=\text { CPCI-S Timespan }=2004- \\
2009\end{array}$
\end{tabular}

\# 16317 TS=(“home injur*” OR "burn injur*”)

Databases $=$ CPCI-S Timespan $=2004-$ 2009

\begin{tabular}{|c|c|c|}
\hline \# 15 & 172 & $\begin{array}{l}\text { TS=(“injury prevention") } \\
\text { Databases=CPCI-S Timespan=2004- } \\
2009\end{array}$ \\
\hline
\end{tabular}

\begin{tabular}{l|l}
$\# 14 \quad 48$ & $\begin{array}{l}\text { TS=("accidental fall } \\
\text { tal injur" OR " } \\
\text { Databases }=\text { CPCI-S Timespan }=2004- \\
2009\end{array}$
\end{tabular}

\begin{tabular}{l|l}
$\# 134$ & $\begin{array}{l}\text { TS }=\text { (“residential fire") } \\
\text { Databases }=\text { CPCI-S Timespan }=2004- \\
2009\end{array}$
\end{tabular}




\begin{tabular}{l|l} 
\#12 1,795 & $\begin{array}{l}\text { TS=(scald* OR suffocat* OR poi- } \\
\left.\text { son }{ }^{*}\right) \\
\text { Databases=CPCI-S Timespan }=2004- \\
2009\end{array}$
\end{tabular}

\begin{tabular}{l|l} 
\# $11 \quad 58,747$ & $\begin{array}{l}\# 2 \text { or } \# 3 \text { or } \# 4 \text { or } \# 5 \text { or } \# 6 \text { or } \# 7 \text { or } \\
\# 8 \text { or } \# 9 \text { or } \# 10 \\
\begin{array}{l}\text { Databases }=C P C I-S \text { Timespan }=2004- \\
2009\end{array}\end{array}$ \\
\hline
\end{tabular}

\begin{tabular}{|c|c|c|}
\hline \# 10 & 720 & $\begin{array}{l}\text { TS }=(\text { local authorit } *) \\
\text { Databases }=\text { CPCI-S Timespan }=2004- \\
2009\end{array}$ \\
\hline
\end{tabular}

\begin{tabular}{l|l}
$\# 923$ & $\begin{array}{l}\mathrm{TS}=(\text { condo OR condominium }) \\
\text { Databases }=C P C I-S \text { Timespan }=2004- \\
2009\end{array}$ \\
\hline
\end{tabular}

\begin{tabular}{l|l}
$\# 8 \quad 30,369$ & $\begin{array}{l}\mathrm{TS}=(\text { building }) \\
\text { Databases }=\text { CPCI-S Timespan }=2004- \\
2009\end{array}$
\end{tabular}

\begin{tabular}{l|l}
\hline \#7 1,013 & $\begin{array}{l}\left.\text { TS=(ergonomic }{ }^{*}\right) \\
\text { Databases=CPCI-S Timespan }=2004- \\
2009\end{array}$ \\
\hline
\end{tabular}

\begin{tabular}{l|l}
\hline \# 6,035 & $\begin{array}{l}\text { TS=(neighbourhood* OR neighbor- } \\
\left.\text { hood }{ }^{*}\right) \\
\text { Databases=CPCI-S Timespan }=2004- \\
2009\end{array}$
\end{tabular}

\begin{tabular}{l|l} 
\# 553 & $\begin{array}{l}\text { TS }=(\text { stairs OR staircase }) \\
\text { Databases }=C P C I-S \text { Timespan }=2004- \\
2009\end{array}$
\end{tabular}




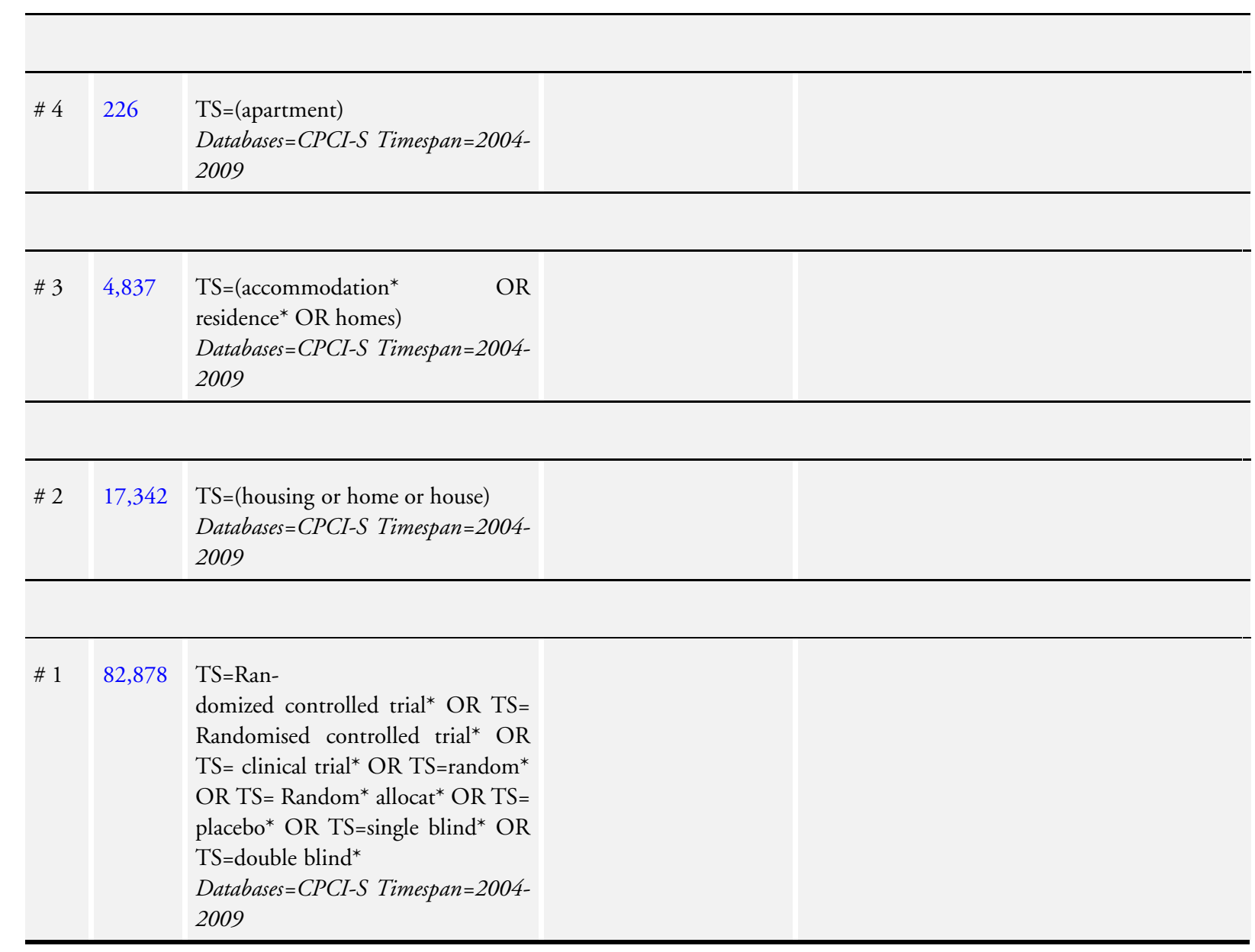

\section{WHAT'S NEW}

Last assessed as up-to-date: 30 November 2009.

\begin{tabular}{|c|c|c|}
\hline Date & Event & Description \\
\hline 3 October 2011 & Amended & $\begin{array}{l}\text { Minor edits have been made to the text which provide additional information about the Gielen } 2002 \\
\text { study }\end{array}$ \\
\hline
\end{tabular}




\section{H I S T O R Y}

Protocol first published: Issue 3, 2002

Review first published: Issue 4, 2003

\begin{tabular}{|c|c|c|}
\hline Date & Event & Description \\
\hline 30 September 2010 & $\begin{array}{l}\text { New citation required but conclusions have not } \\
\text { changed }\end{array}$ & $\begin{array}{l}\text { This updated review includes } 10 \text { new studies identified } \\
\text { in literature searches performed to December } 2009 \text {. } \\
\text { There are } 28 \text { completed published randomised con- } \\
\text { trolled trials and one unpublished study investigating } \\
\text { the effect on injuries of modification of the home en- } \\
\text { vironment. } \\
\text { There are no randomised controlled trials that met the } \\
\text { inclusion criteria in the mixed age group. } \\
\text { There is still insufficient evidence to determine the } \\
\text { effects of interventions to modify environmental home } \\
\text { hazards on injury occurrence } \\
\text { The authors of the review have changed. }\end{array}$ \\
\hline 11 July 2008 & Amended & Converted to new review format. \\
\hline 16 August 2006 & New search has been performed & $\begin{array}{l}\text { August } 2006 \\
\text { This update of the original review includes studies } \\
\text { identified in literature searches performed to Decem- } \\
\text { ber } 2004 \text {. Since the original study a further six ran- } \\
\text { domised controlled trials have been indentified and } \\
\text { the review is now limited to high quality randomised } \\
\text { controlled trials, providing the best evidence available. } \\
\text { There are } 18 \text { completed published randomised con- } \\
\text { trolled trials and one unpublished study investigating } \\
\text { the effect on injuries of modification of the home en- } \\
\text { vironment. } \\
\text { There are no randomised controlled trials that met the } \\
\text { inclusion criteria in the mixed age group. } \\
\text { There is still insufficient evidence to determine the } \\
\text { effects of interventions to modify environmental home } \\
\text { hazards }\end{array}$ \\
\hline
\end{tabular}




\section{CONTRIBUTIONS OFAUTHORS}

ST screened abstracts, critically appraised included studies, wrote updated sections and made review amendments as recommended by the peer referees.

GA screened abstracts, critically appraised included studies, wrote updated sections and made review amendments as recommended by the peer referees.

RL helped to write and edit the protocol, critically appraise included studies, edit updated sections, and suggest review amendments.

AW and MM developed the search strategy, ran electronic database searches, contacted experts, carried out handsearching and reference list follow up, screened records and commented on the review.

SJ critically appraised included studies and updated included studies tables and commented on the review.

AJ critically appraised included studies and updated included studies tables and commented on the review.

SL critically appraised included studies and updated included studies tables and commented on the review.

\section{DECLARATIONS OF INTEREST}

None known.

\section{SOURCES OF SUPPORT}

\section{Internal sources}

- No sources of support supplied

\section{External sources}

- NIHR 2009 Cochrane Review Incentive Scheme, UK. $£ 5000$

\section{NDEX TERMS}

\section{Medical Subject Headings (MeSH)}

${ }^{*}$ Housing; ${ }^{*}$ Interior Design and Furnishings; Accidents, Home [ ${ }^{*}$ prevention \& control]; Controlled Clinical Trials as Topic; Randomized Controlled Trials as Topic; Wounds and Injuries [* prevention \& control]

\section{MeSH check words}

Aged; Child; Humans 